September 2016

"Government Expropriation Increases Economic Growth and Racial Inequality: Evidence from Eminent Domain"

\author{
Daniel L. Chen and Susan Ye
}




\title{
GOVERNMENT EXPROPRIATION INCREASES ECONOMIC GROWTH AND RACIAL INEQUALITY: EVIDENCE FROM EMINENT DOMAIN
}

\author{
Daniel L. Chen and Susan Yeh*
}

Abstract: Is it justified for states to appropriate private property rights? If so, should governments expropriate or regulate? We test three conventional views: insecure property rights cause underinvestment, moral hazard cause overinvestment, or public use cause economic growth. We embed these mechanisms in a model and measure them using the random assignment of U.S. federal court judges setting geographicallylocal precedent. For a half-century, racial minority Democrats were more likely to strike down government appropriations while Republican former federal prosecutors were more likely to uphold them. We find that pro-government physical takings precedent stimulated subsequent takings, expropriation of larger parcels, highway construction, and growth in construction, transportation, and government sectors as well as agriculture, retail, and financial sectors, overall economic growth, and property values. However, racial minorities were increasingly displaced, unemployed, and living in public housing, and the service sector declined. Pro-government regulatory takings precedent also spurred economic growth and property values, but did not increase displacement or racial inequality.

Keywords: Property rights, displacement, regulation, takings

JEL codes: R38, K11, R52

\footnotetext{
*Daniel L. Chen, daniel.chen@iast.fr, Toulouse School of Economics, Institute for Advanced Study in Toulouse, University of Toulouse Capitole, Toulouse, France; dchen@law.harvard.edu, LWP, Harvard Law School; Susan Yeh, Assistant Professor, George Mason University School of Law, syeh2@gmu.edu. First draft: January 2010. Current draft: August 2016. Latest version at: http://nber.org/ dlchen/papers/Government_Expropriation_Increases_Economic_Growth_and_Racial_Inequality.pdf Previous drafts circulated as "Growth Under the Shadow of Expropriation? The Economic Impacts of Eminent Domain." We thank research assistants, numerous colleagues with helpful comments at economic faculties at Harvard, Toronto, CREI, CEMFI, Bern, NBER Summer Institute (Real Estate and Local Public Finance, Environmental and Energy Economics, Income Distribution and Macroeconomics), Stanford SITE Innovation in Economic History Conference, Federal Reserve Bank of New York, Federal Reserve Board of Governors, Econometric Society, American Economic Association, American Public Policy Association Meetings, Royal Economic Society, Society of Labor Economists and law faculties at Northwestern, University of Michigan, University of Southern California, UCLA, University of Illinois Urbana-Champaign, American Law and Economics Association, Conference on Empirical Legal Studies, and Midwest Law and Economics Association Meetings. We thank Andres Sawicki for sharing data. Work on this project was conducted while Daniel Chen received financial support from the European Research Council, Swiss National Science Foundation, Ewing Marion Kauffman Foundation, Institute for Humane Studies, Petrie-Flom Center, Templeton Foundation, Agence Nationale de la Recherche, and the Harvard Law School Summer Academic Fellowship. Both authors received financial support from the John M. Olin Center for Law, Economics, and Business at Harvard Law School.
} 
... nor shall private property be taken for public use, without just compensation.

Bill of Rights - Fifth Amendment in the U.S. Constitution

\section{Introduction}

What are the long-term consequences of common law institutions on growth and inequality? Cross-country empirics attribute $30 \%$ greater stock-market-to-GDP ratios and stronger property rights to common law as opposed to civil law regimes (La Porta et al. 2008), which suggests that the common law can have important effects on economic outcomes through property law. We examine the causal impact of governments' power of expropriation of private property rights on growth and inequality and we measure the channels through which government power has its effects.

A key economic rationale for government expropriation is the failure of Coasean bargaining among numerous property rights owners: Subjective valuation exceeding objective valuation will stymie socially optimal outcomes. Under this view, government power of expropriation leads to economic growth. Yet excessive subjective valuation also occurs when there are high human costs of forced displacement. In India and China, government decisions to expropriate land have led to violent riots. In China alone, the government has taken land from an estimated 40 million households, many of whom have been under-compensated and as a result remain landless, unemployed, and politically restless (Cao et al. 2008). In the former Soviet bloc, legislation allowing governments to expropriate land for the establishment of privately-owned industrial parks is pending. And in the U.S., the Charles River Bridge case of 1837 represents a watershed moment. The Massachusetts government had granted exclusive property rights to private investors to build a toll bridge for traffic across the Charles River, but later eviscerated those rights by building a free bridge nearby, which touched off a dispute in which each side claimed to generate the socially optimal outcome (Lamoreaux 2011). Variously referred to as "eminent domain" (United States), "compulsory purchase" (United Kingdom, New Zealand, Ireland), "compulsory acquisition" (Australia), or simply "expropriation" (South Africa and Canada) in different legal systems, the causal impact of governmental powers of expropriation remains an open question for development economics, macroeconomics, urban economics, economic history, and constitutional law.

The Takings Clause of the Fifth Amendment in the U.S. Constitution states, "... nor shall private property be taken for public use, without just compensation." Court decisions conducting eminent domain jurisprudence focus on the definition of public use and what constitutes justifiable expropriation. The definition of public use has broadened over the twentieth century to include public purpose based on physical, aesthetic, and monetary benefits (Berman v. Parker (1954) held that eradication of blighted neighborhoods qualified as public purpose); conceiveable public purpose (Hawaii Housing Authority v. Midkiff (1984) held that a state can take land that is owned by a small group of private landowners and redistribute it to a wide group of private residents so long as the public purpose be "con- 
ceivable"); and even - economic development (Kelo v. City of New London (2005) held that a transfer of private property to another private entity for the purpose of economic development satisfies the public use requirement). In the last fifty years, judges have decided hundreds of these cases. Major legal precedents range from the building of government dams that caused flooding, building sewers that deprived groundwater from wells, and breaking up oligopolies in land ownership. All of these actions constituted a government taking.

Alongside the birth of the regulatory state, individuals have begun challenging government regulations and even judicial decisions as takings, which has created novel legal debates on whether the government can even restrict how a property owner develops his or her property. Litigations have arisen over regulations that shorten the fishing year, impose zoning restrictions on hotels and gambling, and require enclosure of racing tracks. Takings Clause jurisprudence affects all regulations that potentially restrict how property owners develop their land or even-potentially diminish the economic value of property (Pennsylvania Coal Co. v. Mahon). Regulations that restrict property rights are litigated as government expropriation, yet the modern economy has been characterized as the rise of the regulatory state (Glaeser and Shleifer 2003). The modern administrative state entails regulatory schemes that routinely reassign property rights. Yet, the effect of this sort of state power on American government and society is unknown (Hamburger 2014). The U.S. Federal Courts litigate regulations that can move billions of dollars in stock market prices! Between 1999-2014, Supreme Court decisions moved the market value of publicly traded companies by a net $\$ 140$ billion (Katz et al. 2015). This paper examines the causal impact of government power of expropriation on growth and racial inequality.

Using random assignment and the fact that judges' biographies predict their decisions, we examine whether judges making different legal precedents for millions of individuals residing in one of 12 U.S. Circuits (also known as U.S. Courts of Appeals) matters. Between 1975 and 2008, over 134 Courts of Appeals cases addressing physical takings were decided in the United States, yielding roughly 107 experiments across 34 years and 12 Circuits. While this number may seem small, analysis of state laws usually examine the impact of up to 50 experiments in the U.S. or 34 in the OECD. Since Courts of Appeals are only to hear cases presenting new legal issues, cases representing big legal changes occur throughout the time period. Because judicial composition of eminent domain cases is unlikely to be correlated with subsequent economic outcomes other than through eminent domain decisions, the random assignment of judges creates exogenous variation in legal precedent that can be used to estimate the causal impact of court-made eminent domain law on growth and racial inequality.

One of the key identification challenges is that judges may make pro-takings decisions when there is urban blight, creating downward bias, or when complementary economic growth is

"Billions of Dollars at Stake in Supreme Court Power Market Fight" (Bloomberg Business, January 19, 2016). 
anticipated, creating upward bias in ordinary least squares estimates between pro-government takings decisions and subsequent economic outcomes. Data limitations have made it practically impossible to study the causal effects of eminent domain, which is rarely exercised in a random fashion. The ideal research design randomly assigns individuals or firms to different legal rules to help resolve uncertainty about consequential impacts of law Abramowicz et al. 2011). Thankfully, individuals are not randomly assigned to different systems of justice, nor are judges randomizing their decisions, but the random assignment of law-making judges provides a close approximation.

Even if eminent domain takings were randomized, general equilibrium effects would be difficult to measure. In addition, few centralized data sources document condemnation: Many different types of property rights are subject to government takings and many levels of government (local, state, and national) have the power of eminent domain. We address both issues by focusing on national-level randomization of court-made laws (jurisprudence) that make it harder or easier for subsequent government actors to "take". The U.S. common law system-random assignment of judges, judges interpreting the facts and the law differently and in a manner correlated with their demographic characteristics, and a system of Circuit Courts with regional jurisdiction-allows us to isolate causal effects and incorporate general equilibrium responses. These general equilibrium effects can include (but are not restricted to) capital and labor migration across Circuits. To be sure, since our unit of analysis is Circuit-year, we are subject to the usual concern that the Circuit-years are, at first glance, analyzed as separate markets. However, we note that since our randomization occurs nationally and repeatedly, the general equilibrium effects of labor or capital mobility across Circuit-years are incorporated into our estimates, and these would be the estimates a judge may be interested in. The precedents themselves may eventually spill over across Circuits but it is not immediate, and citation analysis indicates that the precedential impact is an order of magnitude greater within the Circuit than outside.

Consider Goldstein v. Pataki, which illustrates intuitions. Here, the Second Circuit allowed New York to take land for a private developer to build a basketball arena to attract the New Jersey Nets basketball team, which was in the Third Circuit. Fifty years earlier, an attempt to build a baseball stadium on the same site failed because it was not considered public use. But the expanded definition of public use allowed the taking, which racial minorities and small business owners protested, and the last homeowner evicted from the land was compensated $\$ 3$ million. Note that migration occurs both across Circuit boundaries (the basketball team is now called the Brooklyn Nets) and across time (had a baseball stadium been built, there probably would not be a basketball stadium).

We differ from previous papers analyzing the causal effects of law by proposing an estimation strategy for three separate parameters of policy interest: 1) where the counterfactual is the opposite precedent (What if Goldstein had been decided the opposite way? This is of 
policy interest to a decision-maker determining a case already in front of him or her.), 2) where the counterfactual is no precedent (What if Goldstein did not exist? This is of policy interest to a decision-maker factoring in the decision to appeal.), and 3) the local effects of the decision (What if Goldstein's basketball arena did not exist in the original zip codes where the alleged taking took place? This is of policy interest to a decision-maker considering a taking) using data collection from both Circuit and District Courts and linking the Circuit cases to the originating zip code(s).

It is important to note that the U.S. Federal Courts, and in particular, the U.S. Courts of Appeals, have strong impact on government power of expropriation. Only $2 \%$ of Courts of Appeals cases successfully appeal to the U.S. Supreme Court, so U.S. Courts of Appeals determine the vast majority of decisions that set legal precedent and $98 \%$ of their decisions are final. Their decisions are binding precedent within the Circuit, but not outside. They are persuasive precedent on the state courts within the Circuit. In all acts of eminent domain, the government must initiate court proceedings. Regulations that are litigated as expropriation fall under Circuit jurisdiction. Since the Courts of Appeals judges are revealed substantially after the briefs are filed and after litigation costs have been sunk at both the District and Circuit Court level, very few cases settle when the judges are revealed. We also note that the U.S. Courts of Appeal only handles issues of new law-so we should not expect Courts of Appeals cases to influence the decision of a subsequent case that appears in the Circuit.2

Guided by the only set of theoretical models in the scientific literature that we are aware of, we embed conflicting views of eminent domain in a simple model whose predictions are consistent with the previous models in the literature. We recognize that we do not have data on every modeling assumption or modeling parameter, so reduced form predictions isolate the channel through which government takings have their effects. Ex ante, the signs of the effects of eminent domain laws on subsequent economic outcomes are theoretically ambiguous. Models in law and economics emphasize how compensation for takings creates moral hazard for property owners, leading to over-investment because property owners do not pay the insurance they receive in the event of a taking that makes their investment generally worthless (Blume, Rubinfeld and Shapiro 1984; Miceli and Segerson 1994; Innes 1997). Property owners may even over-develop to deter government actors from taking their property instead of someone else's property. Models in the development literature found that if governments compensate too little, then the property owner receives less return on his or her investment, leading to under-investment Besley 1995; Banerjee et al. 2002, Hornbeck 2010). Models in macroeconomics predict that the extractive capacity of the state (i.e., tax technology or shadow of expropriation) leads to faster economic growth because of the public benefits (Mayshar et al. 2011; Slemrod and Yitzhaki 2002; Aguiar and Amador 2011). As far

\footnotetext{
${ }^{2}$ In any event, when we run the reduced form relationship between previous judicial assignment and future laws, there is little apparent effect.
} 
as we are aware, "shadow of expropriation" was first used in the economics literature to model foreign investment (Aguiar and Amador 2011), but the concept is apt for eminent domain power since common law precedent involves both the threat and the actual expropriation.

We explore how closely our empirical design emulates a randomized control trial, addressing the problems of omitted variables, reverse causality, and identification of the multiyear response to prior years' decisions. We verify there are no effects in four years of leads before the decision, which is an important omnibus check of potential endogeneity in violation of our research design. We buttress the assumption that demographic characteristics of assigned judges in published cases are exogenous, linked to economic outcomes only through legal precedent, and that the pro-takings/pro-property owner dimension of these cases is the only channel through which eminent domain doctrine has an effect. We also assuage common concerns levied against randomized control trials (RCTs) - i) whether the LATE interpretation of IV estimates is policy relevant and ii) whether general equilibrium effects, including delayed effects, are incorporated.

We assess whether biographical characteristics not used in the first stage are correlated with residuals in the second stage regression. They are not, which suggests that either the pro-takings vs. pro-property owner dimension of these eminent domain cases is the primary channel through which eminent domain jurisprudence has an effect, or other aspects of eminent domain jurisprudence are not polarized along judicial demographic characteristics, which assuages concerns that we pick up something other than pro-takings vs. pro-property owner doctrine. It also assuages concerns that our identification strategy spuriously picks up the effects of legal precedent in another area of law. Each Circuit Court decides many thousands of cases per year, so the judicial panel composition in different legal areas is effectively uncorrelated. Our identification assumption is that the assignment of judicial biographical characteristics correlated with eminent domain precedent is uncorrelated with other social trends, legal decisions, or the assignment in other areas of law of judicial biographical characteristics that predict legal decisions and affect economic outcomes. The large number of biographical characteristics unused in the first stage are equally unlikely to be correlated with the assignment in other legal areas of judicial biographical characteristics that affect decisions in that area and affect economic outcomes.

Results are robust to controls for Circuit-specific time trends and composition of the pool of judges available to be assigned to panels; results are robust to dropping 1 Circuit at a time, varying the lag structure, and collapsing the data to the Circuit-year level; results are robust to using wild bootstrap and simulations that randomly assign legal variation to another Circuit. As Barrios, Diamond, Imbens, and Kolesar (2012) write, "if the covariate of interest is randomly assigned at the cluster level, only accounting for non-zero covariances at the cluster level, and ignoring correlations between clusters, leads to valid standard errors and confidence intervals," which implies similar standard errors across the different methods of accounting for 
clustering at the Circuit or Circuit-year level. We also present tests of randomization, assess additional identification concerns, and present robustness to accounting for the potential for litigants to pursue an appeal in response to prior years' outcomes. We elaborate on the use of randomly assigned judges in the lower courts (District Courts) from which an appeal arises as an additional source of exogenous variation to control for the presence of a case.

Our main findings are that rulings making it easier to take physical property rights spur economic growth and property values but increase racial inequality, as minorities become more likely to be displaced, unemployed, and live in public housing. We explore the mechanisms using data on federal transportation projects, sectoral GDP, and data entry experiments, and find evidence consistent with all three mechanisms upon which prior theories built their models: public use, over-investment, and insecure property rights.

As to what range of impact estimates are reasonable, we are guided by the only set of empirical results in the causal inference literature that we are aware of. These papers find that electrification increased female employment by 9.5 percentage points and population growth by $17 \%$ (Dinkelman 2011), railroad increased income levels by $16 \%$ (Donaldson 2015), rezoning increased employment by 12-21\% and weekly wages by $8-13 \%$ (Busso et al. 2013), cell phone towers increased producer surplus by $8 \%$ and consumer surplus by $6 \%$ Jensen 2007 ), a $1 \%$ increase in government purchases caused $1.5 \%$ increase in output Nakamura and Steinsson 2011), a 1\% increase in road length increased GDP by $9 \%$ and wages by $11 \%$ (Morten and Oliveira 2013), five years of legislation enabling government acquisitions increased median property values by $4 \%$ (Collins and Shester 2011), and randomly assigned roads increased property values by 16\% (Gonzalez-Navarro and Quintana-Domeque 2014). Roughly $95 \$$ billion is spent per year on place-based policies in the U.S. (Kline and Moretti 2014). It is important to note that these are a subset of all the government activities affected by Takings Clause jurisprudence. Our paper presents the advantage of being based on randomization that is naturally occurring, where general equilibrium effects are incorporated. Whether these effects seem large or small depends on one's perspective: Hacker and Pierson (2016) argue that government regulations fueled economic growth throughout the twentieth century and Gary D. Libecap (2011) find that an early form of land regulation in the 19th century-demarcation-increased property values by up to $30 \%$ and had lasting effects persisting across two centuries. The interpretation of these estimates - and ours - is subject to the usual caveats in the literature (Deaton 2010) - causal effects are sufficient, but not necessary conditions for an outcome 3

We begin our analysis by documenting that our cases are subsequently cited by state statutes and treatises inside-but not outside-the Circuit Court's regional jurisdiction, which

${ }^{3} \mathrm{~A}$ defendant who shares the same first initial as a judge receives $8 \%$ longer sentences, but this effect only explains 0.03\% variance (Chen and Prescott 2016). See also Deaton's NYU "Debates in Development" lecture on the topic, where he describes causal effects as Insufficient but Non-redundant parts of a condition which is Unnecessary but Sufficient (INUS). 
verifies that Courts of Appeals have persuasive precedent on state courts where most takings cases are litigated. We next establish that the random composition of judicial panels was related to Courts of Appeals eminent domain decisions. Judges who are racial minorities have been found to vote differently from white judges on issues such as affirmative action, race harassment, unions, and search and seizure cases where racial minorities are disproportionately affected (Kastellec 2013; Scherer 2004; Chew and Kelley 2009). Racial minorities have their property disproportionately taken Carpenter and Ross 2009, Frieden and Sagalyn 1991), and minority Democrats were 20 percentage points more supportive of property owners in eminent domain cases from 1950 to 2008 (we refer to judges appointed by Democratic presidents as Democrats for brevity). Federal prosecutors represent the government in Federal Courts, prioritizing which aspects of federal law to enforce on behalf of the government. Federal prosecutors are also known as U.S. Attorneys or U.S. District Attorneys (see references cited in Berdejo and Chen 2016, Chen 2016 on their political decision making). Republican former federal prosecutors were 18 percentage points more likely to uphold a physical taking, reflecting both business and government interests.

Next, we show that jurisprudence making it easier for governments to appropriate property rights affected government actors. Local governments expropriated larger, more expensive land parcels. Parcels were taken more frequently from businesses despite their being more litigious and expensive to displace. Highway construction increased both inside central business districts and as connections to outlying areas. On net, pro-government eminent domain precedent spurred annual economic growth and quarterly house-price growth for four years after the precedent, the largest effects occurring two years after the precedent. Effects on house prices are larger, consistent with over-investment and house prices being more forwardlooking relative to contemporaneous variables like GDP. Notably, sectoral GDP effects are concentrated in areas associated with public infrastructure projects: construction, transportation, and governmental. Financial, retail, and agricultural sectors (but not the service sector) also benefited. Eminent domain precedent also had sizable local effects in the original zip code(s) where the takings case arose.

Turning to inequality, consistent with studies suggesting that individuals displaced through eminent domain relocate within a few miles, government power to expropriate increased racial minority moves within the same county relative to whites, but no such effect was found for moves outside the county. Racial minorities also became less likely to be employed relative to whites and more likely to live in public housing, consistent with concerns that eminent domain projects do not necessarily employ minorities whose homes or employers were expropriated, or that the projects themselves have unequal distributional effects, e.g., in the seminal study of irrigation dams by Duflo and Pande (2007).

Eminent domain need not be total; it could be partial, as in environmental regulations or zoning laws that limit how property owners can develop land. Regulatory takings decisions 
in favor of government spur annual economic and quarterly house-price growth and benefit white-collar sectors such as services, government, and financial services. However, unlike physical takings, regulatory takings precedent do not displace individuals and, indeed, we find that they do not lead to condemnations or racial inequality in housing, employment, or displacement. They also do not affect construction and transportation sectors. The last result - in our view - is an important manipulation check of the experimental design that contrasts with the effect of physical takings precedent.

The remainder of the paper is organized as follows. Section 2 presents our model and conceptual framework, Section 3 our empirical framework, Section 4 the main results, Section 5 the mechanisms, and Section 6 concluding remarks and limitations.

\section{Theory}

2.1 Eminent Domain Governments intend the power of eminent domain to spur economic growth through the provision of public goods such as highways, utilities, blight removal, and commercial development. These rationales were articulated in the 2005 U.S. Supreme Court case, Kelo v. City of New London, which justified government transfer of land from one private owner to another on the basis that commercial development satisfied the public use requirement of the constitution.

From a theoretical perspective, hold-up problems arise when subjective valuation exceeds objective valuation, so government expropriation is intended to overcome coordination breakdowns between numerous stakeholders (Buchanan and Yoon 2000). With physical condemnation, the government must initiate court proceedings, though typically a purchase offer is made and bargaining occurs under the shadow of the law. Both residential and commercial tenants can be affected; some jurisdictions do not authorize eminent domain for residential properties (Berliner and Coalition 2006). Business owners have noted that re-establishment expenses are insufficient to cover increased rent and remodeling expenses associated with displacement Garnett 2006). Communities have reported concerns about job loss and trouble attracting new businesses after the number of evicted businesses jumped from 39,000 in 1963 to 100,000 in 1971 (Frieden and Sagalyn 1991).

Government compensation for land acquisition has been documented to be lower than fair market value (Munch 1976, Chang 2010), which can reduce ex ante incentives to invest. Perceived under-compensation along with the fact that racial minorities have their property disproportionately taken (Carpenter and Ross 2009, Frieden and Sagalyn 1991) has raised concerns that revenue-seeking governments collude with private developers (Byrne 2005) at the expense of disadvantaged groups. This view is echoed by liberal and conservative Kelo dissenters arguing that taking land from the poor on behalf of a large pharmaceutical company (Pfizer) amounted to "Reverse Robin Hood."

More recently, courts have broadened the rights of individuals to challenge government regulations as a taking. When these regulations deprive the property owner of all reasonable 
use or value of the property, they are deemed a regulatory taking. Examples of alleged regulatory takings include zoning restrictions for the location of hotels (Dexter 345 Inc. v. Cuomo, 2011) and regulations shortening the fishing year (Vandevere v. Lloyd, 2011).

Pennsylvania Coal Co. v. Mahon (1922) established the doctrine of regulatory takings. Palazzolo v. Rhode Island (2001) held that an owner does not waive his right to challenge a regulation as a taking because he purchased the property after the regulation was enacted. As a consequence, many environmental regulations and zoning laws that potentially limit how property owners can use their land are litigated as regulatory takings.

Recently the boundary between physical and regulatory takings has blurred. For example, the local government can build a beach protection, which could constitute a physical taking, or require landowners to build a beach protection, which would constitute a regulation. Litigation has further blurred the test for what constitutes a physical or regulatory takings: from a "diminution-of-value" test (Pennsylvania Coal Co. v. Mahon (1922) held that whether a regulation constitutes a taking that requires compensation depends on the extent of the diminution of the value of the property) to an "economic impact" / "interference with investment-backed expectations" test (Penn Central Transportation Co. v. New York City (1978) held landmark status does not constitute a regulatory taking because it did not prevent the owner from continuing to benefit from the property) to a "permanent physical presence" test (Loretto v. Teleprompter Manhattan CATV Corp. (1982) held that a regulation that is a permanent physical occupation of property is a regulatory taking to the extent of the occupation, regardless of whether there is a public benefit or if the interference to the owner is only minimal) to a "total takings" test (Lucas v. South Carolina Coastal Council (1992) held that a regulation that deprives the owner of all economically beneficial uses of land is a taking unless the use interest was never part of the title to begin with) for whether a regulation constitutes a taking that requires compensation.

Legal precedent develops through analogies. For example, Roe v. Wade extended the right of privacy under the 14th Amendment's Due Process Clause, which was previously interpreted as precluding government interference in freedom of contract 4 Roe $v$. Wade interpreted Due Process as precluding government interference in a woman's decision to have an abortion. This example means that legal precedent develops through analogies at the conceptual level - the impact of cases includes the conceptual innovation, and are not restricted to future instances of identical fact patterns.

2.2 Model Goldstein v. Pataki, a case in our data, illustrates important economic mechanisms and identification concerns. Here, the Second Circuit Court set a precedent allowing New York to take land for a private developer intending to build a basketball arena that would attract the New Jersey Nets, against the wishes of politicians in New Jersey, in the Third Circuit. The project halted in 2006 when litigation began and the Circuit Court de-

${ }^{4}$ See, e.g., Allgeyer v. Louisiana (1897). 
cision occurred in 2008. The last homeowner evicted was compensated $\$ 3$ million in 2010 and the sports arena was completed in 2012, with thousands of apartment units promised by 2025. Fifty years earlier, an attempt to condemn property for a baseball stadium at the same site failed because, at that time, a privately financed baseball park was not deemed appropriate public use; the baseball team later relocated and became the Los Angeles Dodgers. In 2008, racial minorities and small business owners protested the definition of "public" in the Second Circuit's interpretation of the Takings Clause, but community groups (including some minorities) supporting the project were paid at least $\$ 0.5$ million by the developer. The project was adjacent to an increasingly desirable neighborhood in New York City. We know the decision created precedent in both the federal and state courts, since the case was cited as precedent by the New York Supreme Court (a state court) within two years and by the District Court in the Second Circuit in 2012, in both cases allowing a physical takings to benefit private parties.

We present a model of physical and regulatory takings that embeds prominent theories of eminent domain. The model obtains the standard result in law and economics models that any compensation that increases with investment is inefficient (e.g., Blume, Rubinfeld and Shapiro 1984; Kaplow 1986; Innes 1997): Socially optimal investment should take into account the fact that the invested capital is lost when the land is taken. In a second view, takings risk, however, leads to underinvestment, unless there is just compensation (e.g., Besley 1995; Banerjee et al. 2002, Hornbeck 2010). In the third view, takings can lead to growth when public use benefits of government activity are taken into account (Barro 1990). We show that part of the reason for conflicting views on eminent domain is that the benchmark for what is socially optimal varies across prior models.

2.3 Investment by Property Owners The risk-neutral property owner invests $I$ in her property and expects $V(I)$ return from investment. Government compensation $C=C(I)$ is a function of investment. The law requires the government to pay the property owner, taking into account a number of factors including book value (the appraisal price of the property). Factors include market demand; proximity to areas already developed in a compatible manner with the intended use; economic development in the area; specific plans of businesses and individuals; actions already taken to develop land for that use; scarcity of land for that use; negotiations with buyers; absence of offers to buy property; and the use of the property at the time of the taking (60 Am. Jur. Trials 447). The last factor, in particular, is likely to increase with property owner investment.

We assume that compensation increases with investment, but at a decreasing rate: $C(0)=$ $0, C_{I}(I)>0$, and $C_{I I}(I)<0$. Let $\pi$ be the probability that the court allows a taking to occur.

First best optimal investment occurs when marginal benefits equal marginal costs. Following the convention in the literature, "first best" refers to optimal investment when there is no 
government intervention and "second best" refers to optimal investment taking government intervention as given. Moreover, government benefit and costs of takings are omitted when there is no government intervention.

$$
\max _{I} V(I)-I \quad \text { i.e., } \quad V^{\prime}(I)=1
$$

Second best optimal investment is achieved at:

$$
\max _{I}(1-\pi) V(I)-I
$$

i.e.,

$$
V^{\prime}(I)=\frac{1}{(1-\pi)}>1
$$

Since compensation is just a transfer, it does not enter the optimand. With diminishing returns, $V^{\prime \prime}(I)<0$, the second best investment level is below the first best investment level. A taking deprives all value from the original investment, making property owners less willing to invest, but total loss of $V(I)$ from a taking is not necessary for the result.

The property owner, however, takes compensation into account and maximizes the expected return, ER:

$$
\max _{I} E R=\max _{I}\{(1-\pi) V(I)+\pi C(I)\}
$$

The property owner's optimal investment is achieved when:

$$
(1-\pi) V^{\prime}(I)+\pi C_{I}(I)=1
$$

so that

$$
V^{\prime}(I)=\frac{1-\pi C_{I}(I)}{1-\pi}<\frac{1}{1-\pi}
$$

Equation 6 indicates that the property owner always overinvests compared to the second best optimal investment. The only way to eliminate overinvestment is to set $C_{I}(I)=$ $0=C(I)$, which is contrary to the doctrine of "just compensation." However, this assumes the non-zero probability of takings is fixed and uses the second best as benchmark. With exogenous variation in takings risk in our empirical framework, we use the first best as a 
benchmark. From the equations above, we can see that, compared to the first best, "just compensation," $C(I)=V(I)$, results in optimal investment.

2.4 Government Action: Physical Takings Local governments are constrained to follow court precedent. The property owner perceives the probability $\lambda$ of government takings, which is allowed by the court with probability $\pi$. Then, the property owner's expected return is:

$$
\max _{I} E R=\max _{I}\{(1-\lambda)(V(I)-I)+\lambda[(1-\pi) V(I)+\pi C(I)]\}
$$

With the additional uncertainty of government takings, the property owner's optimal investment is achieved at:

$$
V^{\prime}(I)-1-\lambda \pi V^{\prime}(I)+\lambda \pi C_{I}(I)=0 \text { so that } \quad V^{\prime}(I)=\frac{1-\lambda \pi C_{I}(I)}{1-\lambda \pi}
$$

Taking the total derivative of Equation 8 yields the following expression:

$$
d I=\frac{V^{\prime}(I)-C_{I}(I)}{(1-\lambda \pi) V^{\prime \prime}(I)+\lambda \pi C_{I I}(I)}(\pi d \lambda+\lambda d \pi)
$$

With "just compensation," $C_{I}(I)=1$, it follows that $\frac{d I}{d \pi}=0$.

Both over- and underinvestment relative to first best can occur depending on whether $C_{I}(I)$ is, respectively, bigger or smaller than 1. For example, if $C_{I}(I)<1<V^{\prime}(I)$, then $\frac{d I}{d \pi}$ and $\frac{d I}{d \pi_{p}}<0$ because $V^{\prime \prime}(I)<0$ and $C_{I I}(I)<0$. Decisions making it easier for the government to appropriate, which increase actual and perceived probability of government takings and the probability that subsequent courts will rule in favor of the government, lead to underinvestment only if there is under-compensation. Overinvestment relative to first best occurs only if there is over-compensation, i.e., $C_{I}(I)>1$.

2.5 Government Action: Regulatory Takings With regulatory takings cases, there is no compensation when the court rules in favor of the government. We assume $L$ is the loss of investment value. If plaintiffs win, they receive compensation (courts are reluctant to simply reverse a regulation - invalidation of a regulatory ordinance without payment of fair value for the use of the property during the period of the taking is considered a constitutionally insufficient remedy. First English Evangelical Lutheran Church of Glendale v. County of Los Angeles, 482 U.S. 304 (1987)). The compensation should be equivalent to their loss in investment value.

If governments choose between litigating or regulating (Shleifer 2010) (since to initiate a physical condemnation, the government must bring a case to court), then the investor's 
decision becomes:

$$
\max _{I}\left(1-\pi_{p}-\pi_{r}\right) V(I)+\pi_{r}(V(I)-L)-I
$$

where $\pi_{p}$ and $\pi_{r}$ are the probabilities that the court allows a physical or regulatory taking, respectively. If $L$ is a function of investment, then investment also declines with the probability of regulations.

2.6 Public Use As we are guided by the only set of theoretical models in the scientific literature that we are aware of, and these models did not model the direct impact of eminent domain decisions, we extend the model as follows. If public services are a complementary input to private production, and production returns to private capital are more sharply diminishing without public services, then government expenditures increase growth Barro 1990). Let $y=\Phi(k, g)=k \phi\left(\frac{g}{k}\right)$ in a constant returns to scale model, where $y$ is output, $k$ is private capital, and $g$ is public services. An optimal non-zero level of takings can be derived: $\frac{\delta \gamma}{\delta\left(\frac{g}{y}\right)}=\frac{1}{\sigma} \phi\left(\frac{g}{k}\right)\left(\phi^{\prime}-1\right)$, where $\gamma$ is growth. Growth rate increases government power of expropriation if the public infrastructure is small enough such that $\phi^{\prime}>1$ and declines if public infrastructure is large enough such that $\phi^{\prime}<1$. It also reflects the degree of Coasean bargaining among numerous property rights owners and compensation policy.

Barro (1990) makes no mention of eminent domain, but observes that enhanced property rights look like reductions in marginal tax rates. This claim implicitly assumes $C(I)<V(I)$. If eminent domain reduces property rights and increases public infrastructure, then government power of expropriation has ambiguous effects. Inequality increases if those targeted by eminent domain are systematically different from those benefiting from public use projects or if benefits of public projects are unevenly distributed.

2.7 Discussion To summarize, unless public use benefits counteract investment distortions, court decisions that expand government power of expropriation should have no effect on growth or investment when there is just compensation. Government takings and displacement increase if local governments were previously constrained, but GDP, property prices, labor market and housing outcomes, and investment are all invariant to court decisions if $C(I)=V(I)$.

Many studies of eminent domain report under-compensation (Munch 1976, Chang 2010. Fennell 2004; Radin 1982). If $C(I)<V(I)$, then insecure property rights lead to underinvestment, lower property prices, and adverse labor market and housing outcomes (Besley 1995 Field 2005; Hornbeck 2010). Moreover, a precedent making it easier to take may decrease compensation by changing the relative bargaining power of future litigants, further reducing economic growth. Unequal access to courts can theoretically lead to asymmetric bargaining over "just compensation" in the shadow of the law (Mnookin and Kornhauser 1979; Steven- 
son and Wolfers 2006) and empirically lead to different court judgments (Chen et al. 2013; 2015; 2014c; 2016d).

The model is intended to clarify that growth occurs only if the public use benefits are substantial, regardless of whether there is over- or under-compensation. Second, inequality arises with under-compensation. It shows that the oft-stated assertion that any compensation leads to over-investment is not generically true, not without additional behavioral assumptions such as one where property owners over-develop to deter government actors from taking their property instead of someone else's property. The unified framework links government power of expropriation to investment, actual and perceived takings risk, displacement, compensation, inequality, and growth-outcomes that we examine.

2.8 Testing the Empirical Predictions The most robust prediction of the model is that outcomes are likely to differ in Circuit-years that issue pro-government Takings jurisprudence. To test this, we will simply compare the outcomes in Circuit-years with progovernment and pro-property owner Takings jurisprudence and perform robustness checks to confirm that the difference seems to be due to Takings jurisprudence.

To link legal precedent with economic growth, we parameterize $\phi\left(\frac{g}{k}\right)=e^{\rho L a w_{c t}} A_{c t}$. Consider a general dynamic growth equation for log-level of per-capita output:

$$
y_{c t}=A_{c t}+\alpha_{1} y_{c t-1}+\ldots+\alpha_{n} y_{c t-n}+\rho_{0} L a w_{c t}+\rho_{1} L a w_{c t-1}+\ldots+\rho_{n} L a w_{c t-n}+\varepsilon_{c t}
$$

allowing output to depend on $n$ lags of past output and adding an error term.

We assume that $A_{c t}$ evolves according to:

$$
\Delta A_{c t}=g_{c}+\gamma_{0} L a w_{c t}+\ldots+\gamma_{n} L a w_{c t-n}
$$

This allows both current and lagged jurisprudence to affect the growth rate of $A$.

Substituting $\Delta A_{c t}$ into a first differenced version of $y_{c t}$ yields a dynamic panel estimation equation of the following form. Dell et al. (2012) show in Monte Carlo simulations that firstdifferencing is very effective at correctly identifying both level effects and growth effects and that first-differencing avoids relying on cointegration assumptions for identification.

$$
\begin{gathered}
\Delta y_{c t}=g_{c}+\alpha_{1} \Delta y_{c t-1}+\ldots+\alpha_{n} \Delta y_{c t-n}+\gamma_{0} L_{a w_{c t}}+\ldots+\gamma_{n} L_{a w_{c t-n}}+ \\
\rho_{0} \Delta L a w_{c t}+\rho_{1} \Delta \operatorname{Law}_{c t-1}+\ldots+\rho_{n} \Delta \operatorname{Law}_{c t-n}+\Delta \varepsilon_{c t}
\end{gathered}
$$

The "level effects" of law on output appear through $\rho$. The "growth effects" of law appear 
through $\gamma$. Rewriting the $\Delta$ Law terms as Law terms yields:

$$
\begin{gathered}
\Delta y_{c t}=g_{c}+\alpha_{1} \Delta y_{c t-1}+\ldots+\alpha_{n} \Delta y_{c t-n}+\left(\gamma_{0}+\rho_{0}\right) L a w_{c t}+\left(\gamma_{1}+\rho_{1}-\rho_{0}\right) L a w_{c t-1}+\ldots \\
+\left(\gamma_{n}+\rho_{n}-\rho_{n-1}\right) L a w_{c t-n}-\rho_{n} L a w_{c t-n-1}+\Delta \varepsilon_{c t}
\end{gathered}
$$

Relabeling the coefficients on Law yields:

$$
\Delta y_{c t}=g_{c}+\alpha_{1} \Delta y_{c t-1}+\ldots+\alpha_{n} \Delta y_{c t-n}+\sum_{j=0}^{n+1} \beta_{j} L a w_{c j}+\Delta \varepsilon_{c t}
$$

To find the growth effect, consider $\Delta y_{c t-j}=\Delta y$ and $L a w_{c j}=L a w$. Solving yields:

$$
\Delta y_{c}=\frac{g_{c}}{1-\alpha_{1}-\ldots-\alpha_{n}}+\frac{\sum_{j=0}^{n+1} \beta_{j}}{1-\alpha_{1}-\ldots-\alpha_{n}} L_{a w}
$$

so that the growth effect of jurisprudence is simply $\frac{\sum_{j=0}^{n+1} \beta_{j}}{1-\alpha_{1}-\ldots-\alpha_{n}}$, which is identical to $\frac{\sum_{j=0}^{n} \gamma_{j}}{1-\alpha_{1}-\ldots-\alpha_{n}}$ since the $\rho$ terms all cancel.

As we find variation in Law that is randomly assigned, we focus on $\alpha_{j}=0$ for all $j$ and estimate:

$$
g_{c t}=\theta_{c}+\theta_{t}+\sum_{n=0}^{L} \beta_{t-n} L a w_{c t-n}+\Delta \varepsilon_{c t}
$$

where $\theta_{c}$ are Circuit fixed effects, $\theta_{t}$ are time fixed effects, and $L a w_{c t}$ is a vector of annual jurisprudence with up to $L$ lags included. This equation captures the growth effect of law, e.g., the effect of law on features, such as institutions that influence productivity growth.

The growth equation allows separate identification of level effects and growth effects through the examination of $\beta_{j}$. In particular, both effects influence the growth rate in the initial period. The difference is that the level effect eventually reverses itself. For example, a jurisprudential shock may affect government spending, but after a few periods, spending returns to normal. By contrast, the growth effect appears during the jurisprudential shock and is not reversed. A failure to innovate in one period leaves the Circuit permanently further behind. The growth effect is identified as the summation of the jurisprudential effects over time. Following the convention in the growth literature, we are interested in the distributed lag effect and test for joint significance of the lags. 
Another way to think about our research design is that laws are not likely to have an immediate impact. Laws might not be instantaneously capitalized in prices (DellaVigna and Pollet 2007). Expectations or statutory regimes may take time to adjust. In sum, the simple model of takings embeds competing views of eminent domain. Our model suggests that making it easier for the government to reassign property rights, even with compensation, typically leads to lower economic growth because of distortion in investment incentives, unless there is failure of Coasean bargaining among numerous property owners. If there are no public use benefits and there is fair market compensation, a greater risk of takings has no effect on economic outcomes. Introducing under-compensation, a greater risk of takings leads to under-investment and lower property prices, and these investment distortions would invariably lead to lower economic growth. Positive growth effects would be due to the benefits of public projects that redress failure of Coasean bargaining. Positive effects on property prices could be due to the capitalization of public projects or to over-investment.

\section{Empirical Strategy}

3.1 U.S. Courts of Appeals A foundational understanding of the U.S. federal courts is important to understanding our identification strategy, which relies on the law-making function of common law courts. This making of law occurs because a judge's decisions in current cases become precedent for use in future cases in the same court and in lower courts of the same jurisdiction. There are three layers of federal courts: District, Circuit, and the U.S. Supreme Court. The 94 U.S. District Courts serve as the general trial courts, where a jury is drawn to decide issues of facts. If a party appeals the decision, the case goes up to a Circuit Court, which decides issues of law; they take facts as given from District Courts and have no juries. The 12 U.S. Circuit Courts, also known as federal appellate courts, are only to hear cases presenting new legal issues (only 10-20\% of District Court opinions are appealed). Cases that reach the Courts of Appeals are the more challenging and controversial cases with the greatest likelihood to set new precedent. Figure 1 displays District Court boundaries in dotted lines and Circuit Court boundaries - encompassing between 5 and 13 Districts each - in solid lines. The Federal Circuit Court does not have jurisdiction based on geography and handles mostly patent cases, so is omitted.

In deciding issues of law, Courts of Appeals provide new interpretations or distinctions of pre-existing precedents or statutes. These new distinctions expand or contract the space under which an actor is found liable (Gennaioli and Shleifer 2007). For example, in Martino v. Santa Clara Valley Water Dist., 703 F.2d 1141, the Ninth Circuit held that a taking had occurred, when the local government issued an ordinance requiring that the property owner obtain permits and establish dedications for a flood control project before the property owner could develop his property. In Moore v. Costa Mesa, 886 F. 2d 260, which distinguished Martino, the Ninth Circuit subsequently held that a conditional variance that affects only a small portion of the property owner's property is not a taking. 
Each Circuit Court decides many thousands of cases per year (less than 1 case per Circuit per year is related to eminent domain), but only $2 \%$ of Circuit cases successfully appeal to the U.S. Supreme Court, so Courts of Appeals determine the vast majority of decisions each year that set legal precedent. Circuit Court decisions are binding precedent, but only within that Circuit. When Circuits choose to adopt the precedent of another Circuit, it is typically with some delay: before an opinion can be issued in the new Circuit, a case bringing the same issue of law must be filed in a District Court, appealed to the Circuit Court, and decided upon. Circuit Court decisions are persuasive precedent on state courts within the Circuit. Persuasive precedent must be adopted by the state courts to become binding precedent.

Each case in the Courts of Appeals receives three randomly assigned judges out of a pool of judges, numbering roughly 8 to 40 depending on the size of the Circuit. These judges are appointed for life by the U.S. President and their positions and decisions are highly esteemed. Except for retirement, Courts of Appeals judges typically leave the bench only for a position in the U.S. Supreme Court. State officials are instructed to establish and annually update a set of guidelines based on federal and state law to assist state agencies in identifying and analyzing actions that may result in a taking; they have reported adjusting their acquisitions and land-use regulations to avoid exposure to costly litigation after Courts of Appeals decisions (Frost and Lindquist 2010, U.S. Department of Transportation, Federal Highway Administration 2005; Pollak 2001). Even in matters of an easement for a bicycle path, government actors refrained from the exactment because of their attention to regulatory takings precedent in the Courts of Appeals (Pollak 2001). Newspapers, advocates, and community organizers highlight change in the legal landscape after Courts of Appeals decisions (Pastor 2007; Eagle 2007; Sandefur 2005) and property owners perceive greater takings risk after major eminent domain decisions (Nadler and Diamond 2008, Nadler et al. 2008). Since judges follow precedent (Chen et al. 2014a) and markets respond to Courts of Appeals decisions Araiza et al. 2014), we may expect to see an effect of Circuit Court decisions on property buyers, sellers, and government actors.

The courts are polarized by group identity, personal experience, and legal philosophy. A large literature documents the causal effects of biographical characteristics, experience, and legal philosophy on judicial decisions. For example, law and economics thought causes conservative jurisprudence, Courts of Appeals judges behave more partisan before Presidential elections, wins and losses of sports games affect judicial decisions, ideological perfectionism affects decisions, decisions on recent cases affect the next decision, and explanatory power of extraneous factors persist after employing the best prediction models of judges' decisions Ash et al. 2016; Barry et al. 2016, Berdejó and Chen 2014; Chen 2016; Chen and Eagel 2016; Chen et al. 2015a; 2014, 2015b; 2016c; 2016b).

In our setting, racial minority Democrats have worked for the NAACP, a civil rights organization that advocates for racial minorities and backed the Private Property Rights 
Protection Act (if the Act passes, a state or political subdivision that exercises eminent domain for economic development would be cut off from receiving federal economic grants for two years). Republican federal prosecutors have prior experience advocating on behalf of business and government interests. The assignment of these judges results in different outcomes. In some Circuits, judges are randomly assigned when cases arise, while in other Circuits, judges are randomly assigned to panels up to a year in advance and cases are randomly assigned to panels. Some judges take a reduced caseload if retired or visiting, but all are randomly assigned by a computer algorithm. From discussions with government officials at the Courts of Appeals, it appears that randomization occurs. More importantly, in Chen and Sethi (2011), they formally test for randomization by showing that case characteristics as determined by District Courts are not correlated with the characteristics of the Circuit judges assigned to the case.

\subsection{Data}

3.2.1 Legal Cases We follow and use the regulatory takings database collected by Sunstein et al. (2006). We employ an identical methodology to create a physical takings database of 180 physical takings precedents from 1950-2008. First, we select major Supreme Court precedent: Berman v. Parker, 348 U.S. 26 (1954); Hawaii Housing Authority v. Midkiff, 467 U.S. 229 (1984); Loretto v. Teleprompter Manhattan CATV Corp., 458 U.S. 419 (1982); Kelo v. City of New London, 545 U.S. 469 (2005); Yee v. City of Escondido, 503 U.S. 519 (1992). We include Loretto $v$. Teleprompter because it involves a physical presence of government and may have subsequently guided government officials as to what constitutes a physical taking. Second, we select all Courts of Appeals cases citing these cases. Third, we restrict to three-judge cases that discussed whether the government had physically invaded, was present on the property, or had taken the property. These cases focus on the meaning of "public use" and what constitutes a taking (damages would be determined by finders of fact in District Courts whereas Circuit Courts focus on matters of law). Fourth, we remove cases that overlap the regulatory takings database. For 1976-2008, 33 cases are removed, resulting in 134 cases in the analysis frame. Finally, we coded the Circuit decisions to the zip codes where the alleged taking took place.

Figure 2 shows a map for the location of original Courts of Appeals takings controversies in our database. The Eleventh Circuit was created in 1981 by splitting it off from the Fifth Circuit; Fifth Circuit decisions before this split are considered binding precedent in the Eleventh Circuit. We account for this in our analyses. A wide range of economic policies are affected by Takings Clause jurisprudence. Policies affected by physical takings jurisprudence include dams, sewers, beach protection, and river-diversion. Regulations are also affected because physical takings precedent influences regulatory takings precedent even if the 33 regulatory takings cases are excluded. The cases in our physical takings database include litigation around a government-built dam that flooded land, sewer construction that deprived 
property owners of well water, beach protection, and government diversion of a river. A vote is coded as pro-property owner if the judge voted to grant any relief to the party alleging a violation of the Takings Clause. Appendix Table 1 provides the list and coding of cases. Figure 3 plots the quantity of eminent domain cases that were decided pro-property owner or pro-government over time and Table 1 displays summary statistics. There are 0.33 physical takings Circuit cases per Circuit-year; $27 \%$ of Circuit-years had physical takings cases.

We restrict our cases to physical takings precedent, but because of the blurring of the boundaries between physical and regulatory takings (both in terms of the government actions and the threshold tests), physical takings precedent may subsequently be cited by regulatory takings cases or by local government actors when issuing regulations. Thus, our data may be overinclusive. As placebo check, we utilize the collation by Sunstein et al. (2006) of 220 regulatory takings precedents in Courts of Appeals from 1979-2004. The cases were identified by tracking the citations of the following landmark Supreme Court decisions: Lucas v. South Carolina Coastal Council, 505 U.S. 1003 (1992); Nollan v. California Coastal Commission, 483 U.S. 825 (1987); Keystone Bituminous Coal Ass'n v. DeBenedictis, 480 U.S. 470 (1987); and Penn Central Transportation Co. v. New York City, 438 U.S. 104 (1978). The data includes a range of regulatory takings decisions regarding zoning restrictions on hotels and gambling, noise regulations requiring enclosure of car racing facilities, and environmental regulations shortening the fishing year. Regulations should not be expected to have the same effects as physical takings on highway construction and racial inequality.

We collected District Court cases, state court cases, and state treatises that cited our Circuit Court cases. We also collected District Court cases that cite the same Supreme Court precedents as our Circuit cases, administrative data on these cases from the Administrative Office of the U.S. Courts (AOC), and PACER filings on District Court cases. Sixteen years of Public Access to Court Electronic Records are available on open source sites for 33 Districts. We used PACER data to obtain judge identities that are missing in the AOC data. The latter two datasets, together, assess whether judicial biographies affect the publication of District cases.

3.2.2 Judicial Biographies We compiled information on judges' characteristics from the Appeals Court Attribute Data, District Court Attribute Data. 5 Federal Judicial Center, and our own data collection. The final dataset includes information on vital statistics. Variables include: geographic history, education, occupational history, governmental positions, military service, religion, race, gender, and political affiliations. Raw data on religion come from Goldman (1999) . $^{6}$ Judges whose religions remained missing or unknown were coded as having no publicly known religious affiliation. As social issues divide starkly along religious lines in the U.S., it is reasonable to hypothesize that judges with different religious to may come to

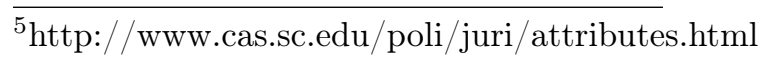

${ }^{6}$ Additional religion data are available at http://courseweb.stthomas.edu/gcsisk/religion.study.data/cover.htm. 
different conclusions in certain cases (Chen and Lind 2007, 2014). We filled in missing data by searching transcripts of Congressional confirmation hearings and other official or news publications on Lexis.

In our data analysis, the average Circuit-year includes 17.66 judges who are available for assignment to panels. Judges occasionally visit from District Courts or specialized courts. In robustness checks, we omit visiting judges. The expected number of racial minority Democrats per seat is 0.06, and the expected number of Republican former federal prosecutors per seat is 0.04 (Table 1). We calculate the expectations based on the composition of the Circuit pool of judges available to be assigned in any Circuit-year assuming that all judges have an equal probability of assignment. Expected number of judges per seat is a proportion varying from 0 to 1. Senior judges sit less frequently and we weigh their characteristics accordingly in calculating expectations. In robustness checks, we omit senior judges and use the exact months in which judges are appointed or retire to calculate their availability.

3.2.3 Economic Outcomes We constructed a panel of roughly 40,000 zip codes followed quarterly from 1975 to 2008 by using Fiserv Case-Shiller Weiss house-price indices at the zip code level. We merge this data at the annual level. When zip code-specific price indices were unavailable, we substituted the price index for the next geographic level (e.g., county, then division, CBSA, or state). This imputation is standard in the literature. It should not affect our results since we cluster our standard errors at a higher level. The indices are based on repeat sales data on single-family homes.

A limitation of Fiserv is that the type of land being sold may change in response to takings law, so we also collected repeat mortgage transactions handled by Fannie Mae or Freddie Mac, from the Federal Housing Finance Agency. We also used house-price indices in the 20 metropolitan areas provided by S\&P Case-Shiller. An earlier draft presented replications of our findings in both datasets. We calculated zip code-specific population estimates for 2005 from the U.S. Census. As standard in the literature, we weight our analyses by population, which alleviates the concern that Fiserv may include non-residential zip codes.7

We obtain state-level yearly GDP from the Bureau of Economic Analysis. We aggregate across all industries by year 8 The average local GDP growth of $5 \%$ is very close to the annualized average quarterly change in log price index of $1.2 \%$ in our data. Sectoral GDP is obtained from the same source. Since industry categorization changes in 1998, we omit 1998 when examining first-differences.

We obtain residential displacement, housing, and labor market outcomes from the Current Population Survey (CPS). We weight our analysis with CPS-provided weights.

3.2.4 Government Actions As far as we are aware, only one dataset uniformly measures the exercise of eminent domain across jurisdictions. The Uniform Relocation Assistance and

${ }^{7}$ The Census data documentation is located at: http://www.census.gov/prod/cen2000/doc/sf1.pdf.

${ }^{8}$ http://www.bea.gov/regional/gsp/default.cfm\#download. 
Real Property Acquisition Policies Act of 1970 ("Uniform Act") and its regulations require states to report statistics related to in-state real property acquisitions by governments for all highway and transportation projects receiving federal aid.

To acquire property, local governments must offer just compensation to the owners and give the owners reasonable time to consider offers. Condemnation proceedings occur only after the parties are unable to reach an agreement through negotiations required by the statute. Around $80 \%$ of the property acquisitions are settled before the government pursues a condemnation proceeding, but our data include settlement. In a property acquisition, displaced residents are also eligible to receive reimbursements for relocation expenses and the added costs of obtaining replacement housing, and displaced businesses are eligible for moving and reestablishment expenses, up to specific ceilings.

We collected annual state-level real property acquisitions, condemnations, compensation, and displacement expenses for 1991-2009 from the Federal Highway Administration..$^{9}$ Specifically, we collected: aggregate compensation for all parcels acquired per state-year whether through open market purchase, condemnation, or administrative settlement, aggregate parcels acquired per state-year, and displacement and relocation costs.

We correlate these statistics with sectoral GDP and find that all sectors, except for the service sector, are positively correlated with condemnations. Notably, we also find that progovernment physical takings precedent has a negative impact on the service sector.

We also collected data on miles of highway construction from 1950 to 2008. The data is obtained from the Form PR-511 Database and Federal Highway Administration publications. We collected 2-digit highways (rays away from MSAs that connect central business districts with regions outside the central city), 3-digit highways (circles around MSAs that primarily serve urban areas), 2-digit federal highways (interstate between MSAs), and planned highways. This data was used in a prior study that found that highway construction caused economic growth (Baum-Snow 2007).

We do not imply that eminent domain only affects highway construction-the wide range of economic policies affected by our physical takings database includes dams, sewer construction, beach protection, and river-diversion-and the modern administrative state entails regulatory schemes that routinely reassign property rights. Rather, we used these data because it is collected in a uniform, mandatory manner across jurisdictions, and we have reason to believe the government actions being measured would impact economic growth and racial inequality (Semuels 2016).

3.3 State Response to Courts of Appeals Precedent The vast majority of takings are initiated by state and local officials and litigated in state courts. So, before proceeding, we present evidence that our takings precedents are followed by states within the Circuit but not outside. We find that state governments enact statutory amendments to comply ${ }^{9}$ http://www.fhwa.dot.gov/realestate/rowstats/index.cfm. 
with Circuit Court decisions, and state courts write decisions in response to Circuit Court precedent.

First, citation counts indicate that our physical takings cases are cited by state statutes and treatises ten times as frequently within the Circuit than outside the Circuit (the average number of citations per state by state statutes and treatises is 0.55 inside the Circuit and 0.05 citations outside the Circuit). For regulatory takings, inside the Circuit, they receive 0.7 citations by state statutes and 1.1 citations by treatises, but outside the Circuit, 0.03 citations by state statutes and 0.3 citations by treatises.

Second, we read each case involving state or local government officials. ${ }^{10}$ The reason for the citation reveals that state citations to cases where the state lost are statutory amendments complying with the Circuit Court precedent. In one exception, the purpose of the citation was to distinguish from the Courts of Appeals decision 15 years later, which suggests that the decision was presumed to be precedent in the meantime.

We also examined the subsequent state reaction to 15 Courts of Appeals judgments where the state lost the case ("pro-property owner" cases). These 15 cases, which come from the 48 pro-property owner Courts of Appeals decisions in the sample of 220 total regulatory takings cases, were subsequently cited in state annotated statutes inside the relevant Circuit. In 3 of the 15 cases, the state clearly reacted to the Circuit Court judgment. In the remainder, the case was included in a list of citations that reflected an annual update of relevant federal and state law.

For example, Kruse v. Village of Chagrin Falls, 74 F.3d 694 (6th Cir. 1996) (OH): Landowner's takings claim ripe for review under federal law because there were no other reasonable remedies available to them under Ohio's appropriation statutes after a taking occurred without notice or compensation; no statutory framework existed for inverse condemnation claim. And writ of mandamus, at best a wholly equitable and post-injury procedure, was inadequate (Ohio Rev. Code $\S \S 163.01-163.62$ ).

State reaction: In State ex rel. Hensley v. City of Columbus, 2011 Ohio 3311 (Ohio Ct. App., Franklin County, 2011) the Ohio Court of Appeals implicitly highlighted the fact that for 15 years the presumption was the Circuit Court law was in force. It indicated that, contrary to 6th Circuit's decision in Kruse, mandamus is the appropriate means to compel proceedings to compensate for a taking of private property, pursuant to a 1994 decision of the Ohio Supreme Court (State ex rel. Levin v. Sheffield Lake, 1994 Ohio 385).

Philip Morris, Inc. v. Reilly, 312 F.3d 24 (1st. Cir. 2002) (MA): Invalidated state disclosure law requiring publication of lists of cigarette additives, since lists were trade secrets protected by takings clause. (Mass. Gen. Laws ch. 94, § 307B).

State reaction: Currently pending legislation would reinstate statute with a section indi-

${ }^{10} \mathrm{We}$ do not include cases where the federal government is litigant as those cases would go to the Federal Circuit. 
cating that a tobacco company's cigarette additive list would be protected as a trade secret to the extent provided under federal law. (Mass SB 1120, apparently about to be passed; referred to senate ethics and rules committee Sept. 24, 2012.)

Dakota, Minn. \& R.R. Corp. v. S.D., 362 F.3d 512, (8th Cir. 2004) (SD): Invalidated portions of statute delegating state's eminent domain power to railroads, since it granted utilities easements in the railroads' rights-of-way without charge, which constituted a taking of railroad property without just compensation. (S.D. Codified Laws $\S 49-16 \mathrm{~A}-75.3(5)$ ).

State reaction: In Dakota, Minn. \& E. R.R. Corp. v. Rounds, 422 F. Supp. 2d 1073 (D.S.D. 2006), the District Court noted pending amendments to the offending statute, which would require a reasonable fee for the easements, would render the case moot; amendments came into effect in June 2006, three months after the District Court decision.

In sum, these quantitative and qualitative citations suggest that we can feel reasonably confident that state courts are predominantly following the precedent of Circuit Courts that contain them.

Moreover, federal courts are also following precedent from the Circuit containing them, but not cases from outside: citations by subsequent Circuit and District cases inside the Circuit are an order of magnitude larger than citations outside the Circuit ${ }^{11}$ Reading these District cases also indicate that District Court cases are following Circuit precedent.

Judicial compliance in District Courts to Courts of Appeals decisions is verified in other quantitative work: A key challenge to examining whether law has precedent using only the data on cases in the courts is to address the endogenous selection of cases into courts based on legal standard. Chen et al. (2014a) examines cases filed before the Courts of Appeals decision but resolved after the decision. Such a methodology requires relatively high frequency judicial decision-making (e.g., on piercing corporate veil cases) for all relevant cases filed in District Courts, along with random assignment of judges setting precedent.

3.4 Empirical Strategy The econometric challenge behind knowing whether common laws have impacts is at least three-fold. First, legal precedent develops through extensive cross-fertilization of legal doctrine between different areas of law via elaborate analogies. The earlier example from abortion jurisprudence highlighted how Roe v. Wade was analogized from freedom of contract: ${ }^{12}$ With cross-fertilization, real outcomes may be misattributed to one legal rule when many legal rules are changing simultaneously. The conventional approach would be to control for other legal rules, but it is practically infeasible to code-much less select-all the possible related doctrinal areas. This example also means that legal precedent develops through analogies at the conceptual level - the impact of cases includes the conceptual innovation, and are not restricted to future instances of identical fact patterns.

Second, Besley and Case (2000) cautioned against causal interpretation of correlations

\footnotetext{
${ }^{11}$ The average case receives 7 citations.

${ }^{12}$ See, e.g., Allgeyer v. Louisiana (1897).
} 
between real outcomes and laws because constituents can influence policies. This concern is a particularly trenchant for court cases (Klarman 2005), because the legal doctrine often instructs judges to take account the community standards, i.e., norms (Chen and Yeh 2013), which feeds into the definition of public use, so it will be difficult to distinguish between laws causing real outcomes from real outcomes causing laws. Courts may also incorporate future trends in decision-making: if property prices are expected to increase, then courts may be less likely to rule that a taking meets the criteria for public use such as blight removal, which would lead to a downward bias in OLS estimates. Or it may be more likely to rule a taking meets the criteria for public use because of anticipated complementarities (e.g., the Goldstein v. Pataki example of building a sport stadium near a booming development), which would lead to an upwards bias in OLS estimates.

Third, judges are consequentialist (Chen and Schonger 2013, 2015): They take into account the potential consequences of their decisions-at least some judges on both the left (Breyer 2006) and right (Posner 1998) do. Judge Richard Posner has lamented that, "[judicial] opinions lack the empirical support that is crucial to sound constitutional adjudication" (Posner 1998); similarly Justice Breyer remarked, "I believe that a[n] interpretive approach that undervalues consequences, by undervaluing related constitutional objectives, exacts a constitutional price that is too high" (Breyer 2006). Consequentialism (in our case, maximizing economic growth or efficiency or minimizing racial inequality or unfairness) can bias the correlation between future outcomes and today's decisions if they desire similar consequences while sitting on other cases.

We overcome these three challenges with random variation in legal precedent using biographical characteristics of judges: We would not want judges to randomize their decisions in the interest of legal science, but the judges themselves are randomly assigned and their background correlates with the way they decide, effectively creating a clinical trial that randomizes pro-government vs. pro-property owner jurisprudence. Policy-makers and scholars have sought to evaluate legal institutions and sought estimates of the causal effects of common law decisions (Posner 1998, Breyer 2006); see also, World Bank Law and Justice Institutions Performance Evaluation and calls for randomizing law (Abramowicz et al. 2011).

Because of the randomization built into the U.S. Federal Courts, the basic empirical strategy is straightforward. The effect of Takings Clause jurisprudence is obtained by comparing the means of the outcomes of interest after pro-government precedent and pro-property owner precedent. Note that this difference is not an estimate of the comparison between pro-government precedent and no precedent. The government and economic activities can be different than what they would have been if there was no precedent whatsoever. We are mostly interested in the effect of pro-government precedent, rather than pro-property owner precedent, when there is a precedent, as this would be the effect of the decision of a judge deliberating on the case. 
Denoting $Y_{i c t}$ as the value of the outcome of interest for individual (state, zip code, or person) $i$ (say, GDP) and Law ct as a dummy equal to 1 if the decision was pro-government, this estimate is simply:

$$
E\left[Y_{i c t} \mid L a w_{c t}=1\right]-E\left[Y_{i c t} \mid L a w_{c t}=0\right] \equiv \beta_{1}
$$

We expect $\beta_{1}>0$ if failure of Coasean bargaining makes $\phi^{\prime}>1$. Since we are interested in effects over time, we specify a distributed lag. We extend our specification to include the presence of a decision, $1\left[M_{c t-n}>0\right]$. We focus on four years of lags and one lead $(n=-1$ to 4) and vary the lag structure for robustness. $M$ is the number of cases, which is typically 0 or 1 (so typically $\operatorname{Law}_{c(t-n)}$ is 1 (100\% pro-government) or 0 (100\% pro-property owner)). Since most of our data is yearly, we take the average law measurements in each Circuit-year, which also preserves the structure of our randomization (the moment condition for causal inference is the easiest to interpret, but previous drafts considered, estimated, and validated robustness to alternative specifications). We also considered weighting our estimates by the number of cases in a Circuit-year, where weights are the geometric mean of $M_{c(t-n)}+1$ over the distributed lag. The statistical significance of the results increases, so we present more conservative estimates without weighting.

$$
g_{c t}=\theta_{c}+\theta_{t}+\sum_{n=0}^{L} \beta_{1 t-n} L a w_{c t-n}+\sum_{n=0}^{L} \beta_{2 t-n} 1\left[M_{c t-n}>0\right]+\varepsilon_{c t}
$$

Analogizing to coin flips, $\beta_{1}$ captures the effect of the heads-or-tails coin flip (pro-government vs. pro-property owner precedent), $\beta_{1}+\beta_{2}$ captures the effect of the heads coin flip and the presence of the coin (pro-government precedent vs. no decision), and $\beta_{2}$ captures the effect of the tails coin flip and the presence of the coin (pro-property owner precedent vs. no decision).

We examine several outcomes: change in log yearly state GDP, change in log quarterly zip code property prices, change in log miles of federal highways, condemnation statistics, whether an individual moved in the last year, and employment status. We will test whether there are differences in outcomes of racial minorities by running the regression:

$$
\begin{gathered}
Y_{i c t}=\theta_{c}+\theta_{t}+\sum_{n=0}^{L} \beta_{3 t-n} L_{a w} w_{c t-n}+\sum_{n=0}^{L} \beta_{4 t-n} 1\left[M_{c t-n}>0\right]+ \\
\sum_{n=0}^{L} \beta_{5 t-n} L_{a w} w_{c t-n} * B_{i c t}+\sum_{n=0}^{L} \beta_{6 t-n} 1\left[M_{c t-n}>0\right] * B_{i c t}+\eta X_{i c t}+\varepsilon_{i c t}
\end{gathered}
$$

$B_{i c t}$ represents a dummy indicator for being non-white. We expect $\beta_{5}<0$ if minorities are disproportionately targeted by eminent domain and there is under-compensation. We report the average and the individual coefficients. We consider $n=0$ as a lag because some statistics 
refer to calendar year. Most of the effects appear with some slight delay so excluding $n=0$ in joint significance tests does not affect our results.

In what follows, we report a mix of robustness checks along with the main results so the reader can make their own judgment as to the most central findings. We are guided by an ordering of presentation that verifies whether the "randomized control trial" works, after which we would present additional outcomes and mechanisms using only the baseline model (earlier drafts had many additional tables).

In principle, we have up to 1,632 experiments (34 years x 12 Circuits (x 4 quarters)). With random treatment assignment, adding controls can add precision to the estimates if the controls are strong predictors of the outcomes. We show (in Tables 4 and 5 and also in the Appendix) that our main estimates are robust to the inclusion or exclusion of:

- Person-level age, gender, and educational attainment, and state-level fixed effects. These enter as dummies with the exception of age.

- Characteristics of judges available to be assigned. We calculate the expectations based on the composition of the Circuit pool of judges available to be assigned in any Circuityear assuming that all judges have an equal probability of assignment. Expected number of judges per seat is a proportion varying from 0 to 1 . Senior judges sit less frequently and we weigh their characteristics accordingly in calculating expectations. The results are not sensitive to omitting senior judges and using the exact months in which judges are appointed or retire to calculate their availability.

- Circuit-specific time trends to allow different Circuits to be on different trajectories with respect to outcomes.

We also present a specification with four years of leads and one lag ( $n=-4$ to 1$)$.

For standard errors, as Barrios, Diamond, Imbens, and Kolesar (2012) write, "if the covariate of interest is randomly assigned at the cluster level, only accounting for non-zero covariances at the cluster level, and ignoring correlations between clusters, leads to valid standard errors and confidence intervals," so we expect to see similar results whether clustering standard errors at the Circuit or Circuit-year level (Barrios et al. (2012) show that random assignment of treatment addresses serial and spatial correlation across treatment units). Our results are also unaffected using the standard approach with U.S. data, 50 state clusters (see Tables 4 and 5). Appendix Tables 4 and 5 also report regressions where each datapoint corresponds to 1 experimental subject (34 years x 12 Circuits). We check results using randomization inference that assigns the legal variation to another Circuit and the robustness of our results to using wild bootstrap. In addition, the leads specification serves as an omnibus check for insufficient adjustment of standard errors. A prior draft clusters standard errors at the Circuit-year level and this draft clusters at the Circuit level, and the 
results are unchanged 13

3.4.1 Instrumental Variable Ascertaining a causal effect from judicial decisions to social trends is difficult without idiosyncratic variation in judicial decisions. Since $L a w_{c t}$ and $\epsilon_{i c t}$ may be correlated due to uncontrolled-for social trends or other legal developments that correlate both with $L a w_{c t}$ and outcomes $Y_{i c t}$, we develop an instrumental variable for $L a w_{c t}$ using judges' biographical characteristics. We use biographical characteristics because the number of eminent domain cases yields sharp demographic effects but not judge-specific effects, as there are too few cases with which to identify judge-specific effects (there are roughly 180 life-time appointed judges and only 134 cases). In this paper, we do not analyze heterogeneity in terms of, e.g., early or late pro-takings decisions, or the compounding effects of, e.g., pro-takings decisions, and we only analyze the average effects.

Judges with different conceptions of duty or empathy may render different decisions. In particular, racial minority Democrats are more likely than racial minority Republicans to have worked for the NAACP, a civil rights organization that advocates for racial minorities and backed the Private Property Rights Protection Act. If the Act passes, a state or political subdivision that exercises eminent domain for economic development would be cut off from receiving federal economic grants for two years. Federal prosecutors have been found to be politically and legally partisan, so we may expect Republican former federal prosecutors to be primed to support business interests and favor government takings.

We develop an instrumental variable using judges' shared biographical characteristics and we will refer to the number of judges assigned to eminent domain panels with these characteristics as $N_{c t}$ (we drop the subscript $n$ to ease the exposition on the instrumental variables construction).

If a Circuit-year has a higher fraction of pro-government judges $\left(N_{c t} / M_{c t}\right)$ assigned, the precedent for that year will be that much more pro-government. Were we only interested in the contemporaneous effect of $\mathrm{Law}_{c t}$, the moment condition for causal inference is $\mathbf{E}\left[\left(N_{c t} / M_{c t}-\mathbf{E}\left(N_{c t} / M_{c t}\right)\right) \varepsilon_{i c t}\right]=0 . \mathbf{E}\left(N_{c t} / M_{c t}\right)$ is the expected proportion of judges who tend to be pro-property owner in takings cases. Figure 3 illustrates the identification strategy. The jagged line displays $N_{c t} / M_{c t}$ and the smooth line displays $\mathbf{E}\left(N_{c t} / M_{c t}\right)$ in each of the 12 Circuits. The smooth lines indicate the underlying variation in judge-specific characteristics within Circuits over time. The jagged line indicates the random year-to-year variation in racial minority Democrats per seat. We estimate how outcomes $\triangle Y_{\text {ict }}$ respond to idiosyncratic variation in excess proportion, $N_{c t} / M_{c t}-\mathbf{E}\left(N_{c t} / M_{c t}\right)$.

Next, we construct an instrumental variable whose moment conditions are implied by the original moment condition. Consider an instrument, $p_{c t}-\mathbf{E}\left(p_{c t}\right)$, where $p_{c t}$ is the proportion of judges who tend to be pro-property owner in takings cases and $p_{c t}$ is defined as 0 when

\footnotetext{
${ }^{13}$ We thank our NBER discussant Bentley MacLeod for recommending for a related paper that we cluster at the Circuit level.
} 
there are no cases:

$$
p_{c t}= \begin{cases}N_{c t} / M_{c t} & \text { if } \mathbf{1}\left[\mathrm{M}_{\mathrm{ct}}>0\right]=1 \\ 0 & \text { if } \mathbf{1}\left[\mathrm{M}_{\mathrm{ct}}>0\right]=0\end{cases}
$$

Without loss of generality, $N_{c t}$ is the number of racial minority Democrats per seat in takings cases in Circuit $c$ and year $t$. These two conditional moment conditions imply $\mathbf{E}\left[\left(p_{c t}-\right.\right.$ $\left.\left.\mathbf{E}\left(p_{c t}\right)\right) \varepsilon_{i c t}\right]=0$ unconditionally: $\mathbf{E}\left[\left(p_{c t}-\mathbf{E}\left(p_{c t}\right)\right) \varepsilon_{i c t}\right]=\operatorname{Pr}\left[M_{c t}>0\right] \mathbf{E}\left[\left(p_{c t}-\mathbf{E}\left(p_{c t}\right)\right) \varepsilon_{i c t} \mid M_{c t}>\right.$ $0]+\operatorname{Pr}\left[M_{c t}=0\right] \mathbf{E}\left[\left(p_{c t}-\mathbf{E}\left(p_{c t}\right)\right) \varepsilon_{i c t} \mid M_{c t}=0\right]=0$. Furthermore, $\mathbf{E}\left[\left(p_{c t}-\mathbf{E}\left(p_{c t}\right)\right) \varepsilon_{i c t}\right]=$ $\mathbf{E}\left(p_{c t} \varepsilon_{i c t}\right)-\mathbf{E}\left[\mathbf{E}\left(p_{c t}\right) \varepsilon_{i c t}\right]=\mathbf{E}\left(p_{c t} \varepsilon_{i c t}\right)-\mathbf{E}\left(p_{c t}\right) \mathbf{E}\left(\varepsilon_{i c t}\right)=\mathbf{E}\left[p_{c t} \varepsilon_{i c t}\right]$. Thus, $p_{c t}$ and $p_{c t}-\mathbf{E}\left(p_{c t}\right)$ both serve as valid instruments. Notably, as Tables 4 and 5 and the Appendix show, the results are unaffected by controlling for $\mathbf{E}\left(p_{c t}\right)$. As Table 2 shows, $\mathbf{E}\left(p_{c t}\right)$ is uncorrelated with $L a w_{c t}$. These checks assuage concerns that $\mathbf{E}\left(p_{c t}\right)$ is correlated with outcomes (or correlated with decisions in other areas of law that affect the outcomes we examine) in a manner that drives our results.

This draft presents estimates using the following identification assumption (moment condition) for causal interpretation: $\mathbf{E}\left[\frac{N_{c t}}{M_{c t}} \varepsilon_{i c t} \mid \mathbf{E}\left(\frac{N_{c t}}{M_{c t}}\right), 1\left[M_{c t}>0\right]\right]=0$. Early drafts obtained similar results using $\mathbf{E}\left[N_{c t} \varepsilon_{i c t} \mid \mathbf{E}\left(\frac{N_{c t}}{M_{c t}}\right), \mathbf{1}\left[M_{c t}>0\right], M_{c t}\right]=0$, which looks at the number of protakings decisions controlling for the number of decisions, and $\mathbf{E}\left[N_{c t} \varepsilon_{i c t} \mid \mathbf{E}\left(\frac{N_{c t}}{M_{c t}}\right), \mathbf{1}\left[M_{c t}>0\right], Q_{c t}\right]=$ 0 , which controls for the size of the court docket and checks if pro-takings vs. pro-property owner decisions had opposite-signed effects. For the reasons we outline next, checking for opposite-signed effects is a poor test, and this motivates our current specification.

All lags and leads of $L a w_{c t}$ are instrumented for in the actual implementation. As standard, we also lag and interact the instruments as we lag and interact $L a w_{c t}$.

3.4.2 Interpretation of $\beta_{1 n} L a w_{c(t-n)}+\beta_{2 n} \mathbf{1}\left[M_{c(t-n)}>0\right]$ : Dummying for the presence of a case permits identification of additional counterfactuals.

- $\beta_{1 n}$ captures the effect of pro-government precedent where the counterfactual is a proproperty owner precedent.

- $\beta_{1 n}+\beta_{2 n}$ captures the effect of pro-government precedent where the counterfactual is no precedent.

- $\beta_{2 n}$ captures the effect of pro-property owner precedent where the counterfactual is no precedent.

3.4.3 Interpretation of 2SLS: In common law, hard cases are the compliers whose decisions turn on the identity of the judge and they lack strong legal precedent. Hard cases precede easy cases, which are the always/never-takers. Easy cases follow the legal precedent established previously. Cases that reach the Courts of Appeals are the more challenging and legally innovative cases. According to Courts of Appeals judges, 5-15\% of cases are "legally 
indeterminate" and have no strong legal precedent (Edwards and Livermore 2008). These are the cases where judges seek guidance, and at present, from policy arguments that speculate about the consequences of a legal rule (Posner 1998; Breyer 2006; Abramowicz et al. 2011). Ambiguity has been shown theoretically to cause polarization along partisan lines Baliga et al. 2013). Since judges follow precedent, the complier cases precede the always-taker/nevertaker cases.

At first glance, our 2SLS estimates capture only the effects of hard cases, and as typical in the instrumental variables literature, the external validity is limited to the sets of cases likely to respond to the instrument. On a second look, $\beta_{1 n}$ captures the effect of hard cases $n$ years ago, which can be decomposed into delayed direct effects as well as the effects of subsequent easy cases that cite these hard cases. That is, $\sum_{n=0}^{\infty} \beta_{1 n}=\sum_{n=0}^{\infty} T O T_{c t}^{n}=\sum_{n=0}^{\infty} L A T E_{c t}^{n}$ even though in general, we only know $L A T E$ and not TOT. Recall, TOT $\equiv E\left[Y_{1 i}-Y_{0 i} \mid R_{i}=1\right]=$ $E\left[Y_{1 i}-Y_{0 i} \mid R_{1 i}>R_{0 i}\right] \operatorname{Pr}\left(R_{1 i}>R_{0 i} \mid R_{i}=1\right)+E\left[Y_{1 i}-Y_{0 i} \mid R_{i}=1\right] \operatorname{Pr}\left(R_{1 i}=R_{0 i}=1 \mid R_{i}=1\right)$, where $R_{i}$ indicates whether $i$ received treatment, $R_{1 i}>R_{0 i}$ indicates whether individual $i$ is a complier and $R_{1 i}=R_{0 i}=1$ denotes an always-taker, under the assumption of no defiers.

Indirect inference suggests that the effect of hard eminent domain cases is largely through cases subsequently not litigated or not published in Courts of Appeals: few cases occur per Circuit-year and contemporaneous judicial composition is not correlated with subsequent takings decisions in the Circuit. The absence of subsequent easy cases following prior hard cases in the published record is not surprising since Courts of Appeals cases should bring issues of new law. Litigants should settle the easy cases, even if they do not, judges should leave easy cases unpublished. Since published cases are predominantly hard cases, they are responding to biographical characteristics. In addition, the strong first stage suggests that any bias that results from the presence of non-compliers is likely to be small. The bias from non-monotonicity is given by $\frac{\operatorname{Pr}[\text { Defier }]}{\operatorname{Pr}[\text { Complier }]-\operatorname{Pr}[\text { Defier }]}\left(\beta^{\text {Complier }}-\beta^{\text {Defier }}\right)$, which is likely to be small even if there are non-compliers, since the magnitude of the first stage is large (the denominator grows and the numerator shrinks) using biographical characteristics as the instrument.

More concretely, if a Circuit-year has a higher fraction of Republican former federal prosecutors assigned, the precedent that year will be that much more pro-government. We are interested in the subsequent effects of that precedent on government and economic outcomes. We are able to do so because the identity of a judge on a case does not directly affect outcomes except through the precedent. The court decision is taken as precedent by subsequent courts. Also, judge identity do not predict stock prices at the time of resolution controlling for the manner in which the case was resolved and judge identity do not predict stock prices at the moment that judges are revealed (Badawi and Chen, 2014).

It is also worth noting that for Takings Clause jurisprudence, pro-government vs. proproperty owner is the materially relevant legal doctrine for economic outcomes. A very in- 
teresting feature of the institutional setting, however, is that it is possible to assess this hypothesis in conjunction with another. If there are other aspects of eminent domain doctrine that are sensitive to judges' biographical characteristics, and if these other aspects of eminent domain doctrine affect government and economic outcomes, we should observe correlations between Circuit-year biographical characteristics not used in the first stage and 2SLS residuals. They are not, which suggests that the pro-government vs. pro-property owner dimension of these cases is the primary channel through which eminent domain doctrine has an effect or that other aspects of eminent domain doctrine are not polarized along judicial demographic characteristics. An early draft of Chen and Sethi (2011) compared the effects of sexual harassment law with gender discrimination law (since these areas of law are closely related) in a specification that included both areas of law and instruments for each. The data on these laws was collected by Sunstein et al. (2006). When each area of law was instrumented for by its assignment of judges, the addition of another area of law did not affect the coefficient on the other area of law, which assuage concerns of leakage.

3.4.4 Interpretation of Experiment vs. Population: The population TOT of the Circuit $=\left(\right.$ Experimental: $\left.T O T_{\text {direct }}\right) * \mathrm{P}\left(\right.$ exposure $\left._{\text {direct }}\right)+\left(T O T_{\text {indirect }}\right.$ of individuals $) *$ $\mathrm{P}\left(\right.$ exposure $\left._{\text {indirect }}\right)$. The experiments estimate $T O T_{\text {direct }}$ for individuals. The known parame-

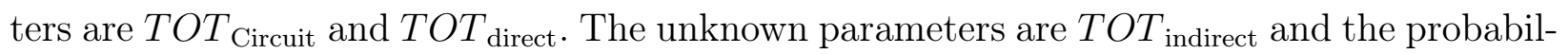
ities. If one's priors are that $\mathrm{P}$ (exposure direct $)$ is small, then indirect exposure may be large. For example, thought leaders may issue cues (Baum and Groeling 2009, Cohen 2003; Bullock 2011; Clark et al. 2014) that shape perceptions after decisions (Dolbeare and Hammond 1968). Data limitations make it practically impossible to study all the channels through which law has its effects, but Clark et al. (2014) finds significant use of Twitter after several court decisions. We will present the results of an experiment where subjects are randomly made aware of a recent Courts of Appeals decision.

3.4.5 Randomization Check According to interviews, each court implements randomization differently. In some Circuits, two to three weeks before the oral argument, a computer program randomly assigns available judges to panels who will hear cases. In other Circuits, judges are randomly assigned to panels up to a year in advance; cases that arise are randomly assigned to panels. Some judges take a reduced caseload if retired or visiting, but all are randomly assigned by a computer algorithm. Senior judges can opt out of death penalty cases in some Circuits, but they would do so before random assignment. Chen and Sethi (2011) formally tests for randomization by showing that case characteristics as determined by District Courts are not correlated with the characteristics of the Courts of Appeals judges assigned to the case.

Even if judges are randomly assigned, because our data comprise published opinions, several additional issues need to be considered: settlement, publication, and strategic use of 
keywords or citation. In Courts of Appeals, judges are revealed very late, after litigants file their briefs, sometimes only a few days before the hearing, if there is a hearing, which gives little opportunity and incentive for settlement upon learning the identity of the panel. Most of the litigation costs are sunk by that point, and when the D.C. Circuit began announcing judges earlier, it did not affect settlement rates (Jordan 2007). Unpublished cases are not supposed to have precedential value. Unpublished cases are deemed as routine and easy: studies find that judicial ideology predicts neither the decision in unpublished cases (Keele et al. 2009) nor the decision to publish (Merritt and Brudney 2001). To rule out strategic use of keywords or citation of Supreme Court precedent, we propose an omnibus test to collectively address deviations from strict exogeneity: we examine how similar the string of actual panel assignments is to a random string, the details of which are developed in Chen (2013). To see random strings as an omnibus test: Suppose racial minority Democrats publish cases and other judges do not. In order for this to explain any effects, we should expect racial minority Democrats to violate the random strings test.

We assess deviations from random assignment by examining whether the sequence of proportions of judges is similar to a random process. Figure 3 suggests visually that panel composition is not serially correlated. Formally, we:

1. Propose a statistic that can be computed from the sequence of numbers of racial minority Democrats per seat within a Circuit.

2. Compute the statistic for the actual sequence, $s^{*}$.

3. Compute the statistic for each of 1,000 bootstrap samples from the actual sequence, i.e., $s_{1}, s_{2}, s_{3} \ldots s_{n}$. Since there were changes in the expected number of racial minority Democrats per seat over time, we treat our bootstrap samples as a vector of realized random variables, with the probability based on the expectation during the Circuityear.

4. Compute the empirical p-value, $p_{i}$ by determining where $s^{*}$ fits into $s_{1}, s_{2}, s_{3} \ldots s_{n}$.

5. Repeat steps 1-4 and calculate $p_{i}$ for each unit.

We use the following statistics:

Autocorrelation: We see if the value in the $\mathrm{j}^{\text {th }}$ case depends on the outcome in the $\mathrm{j}-1^{\text {th }}$ case. This statistic can detect whether judicial assignments are "clustered," meaning a higher than expected number of back-to-back seat assignments to a particular type of judge. This test tells us whether certain judges sought out eminent domain cases, perhaps in sequence.

Mean-Reversion: We test whether there is any form of mean reversion in the sequence, meaning that the assignment in the $\mathrm{n}^{\text {th }}$ case is correlated with the assignment in previous $n-1$ cases. This test tells us whether judges or their assignors were attempting to equilibrate their presence, considering whether a judge was "due" for an eminent domain case.

Longest-Run: We test whether there are abnormally long "runs" of certain types of judges 
per seat. This test tells us whether certain Circuits may have assigned certain judges with eminent domain cases during certain time periods, for example, to achieve specialization.

Number of Runs: Instead of simulating 1000 random strings, we compute the exact statistic for number of runs. This test captures violations of randomization at the case level rather than Circuit-year. In power calculations, this test has less Type II error compared to the other tests. These random strings tests also have lower Type II error compared to regression.

With a truly random process, the collection of all unit p-values should be uniformly distributed. (Imagine that you generate summary statistics for 1000 random strings. The $1001^{\text {th }}$ random string should have a summary statistic that is equally likely to be anywhere from 1 to 1000.) A visual examination suggests that the empirical distributions for our p-values for physical and regulatory takings approach the CDF of a uniform distribution (Appendix Figure 1), which we formally test using a Kolmogorov-Smirnov test statistic from an empirical null.

A final check of randomization is displayed in Appendix Table 2 Panel B. One or two years before the true instrument, judicial decision-making is not correlated with future judicial assignment.

Random strings test complements standard randomization checks (e.g., examinations of (1) leads and (2) correlations between judicial composition and pre-determined case characteristics). If pre-determined covariates occur randomly over time, checks of (2) miss nonrandom serial correlation in judicial composition while the random strings test would miss correlations between judicial composition and pre-determined covariates.

We also stack the strings across Circuits and across biographical characteristics and run an autocorrelation test and compare the F statistic with $\mathrm{F}$ statistics generated from randomly assigning available judges to cases. The results are consistent with randomization.

Other variations from random assignment include: remanded cases from the Supreme Court are returned to the original panel; en banc cases that are heard by the entire pool of judges (or a significant fraction in the Ninth Circuit); judges with conflict of interests opt out after random assignment, which is extremely rare. We do not use remanded or en banc cases, which are also relatively infrequent. Judges can also take sick leave or go on vacation, but this is determined far in advance. Not accounting for vacation, sick leave, senior status, en banc, remand, and recusal can lead to the inference that judges are not randomly assigned (Hall 2010; Chilton and Levy 2015).

Our identification strategy - like the identification strategy of papers that use the patent officer assignment or disability application reviewer assignment, which are not explicitly random (Maestas et al. 2013; Galasso et al. 2015) - assumes that idiosyncratic deviations from random assignment are ignorable. Even a gold-standard random process — the roll of a die - has a deterministic element. If known with precision, the force and torque applied 
to the die, the subtle air currents, the hardness of the surface, etc., might allow us (or a physicist) to determine with certainty the outcome of these "random" rolls. Despite this obvious non-randomness, we would still have faith in the outcome of a trial with treatment assignments based on die rolls because we are certain that the factors affecting the assignment have no impact on the outcome of interest and hence are ignorable.

3.4.6 District Courts Litigants' decision to appeal may respond to previous years' legal decisions, however, so controlling for $\mathbf{1}\left[M_{c t}>0\right]$ may bias the coefficient for $L a w_{c t}$; the bias is more severe for more distant lags and non-existent for the most advanced lead. We assess whether this potential endogeneity is a significant concern by comparing $\beta_{1(t-n)}$ when we instrument for $\mathbf{1}\left[M_{c t}>0\right]$ using the random assignment of District Court judges. District judge demographic characteristics are correlated with reversal rates in the Courts of Appeals (Haire, Songer and Lindquist 2003; Sen 2015; Barondes 2010; Steinbuch 2009); and expected reversal rates could encourage litigants to pursue an appeal. If $\mathbf{1}\left[M_{c t}>0\right]$ and $L a w_{c t}$ are both identified, estimates should be roughly invariant to the inclusion or exclusion of additional lags and leads (including lags that are important predictors of the outcome improves statistical precision, but losing data at the beginning and end period reduces precision) and lead coefficients being 0 provide an omnibus check of our instrumental variable being endogenous to pre-existing trends.

District Courts assign one judge to a case randomly or rotationally (Taha|2009; Bird 1975). Cases being returned on remand from the Courts of Appeals are not randomly assigned. We do not use remanded cases in our dataset. For example, one District told us that random assignment occurs within 24 hours of a case filing, which is handled in the order of its arrival. Waldfogel (1995) reports that one District Court uses three separate randomization wheels and each wheel corresponds to the anticipated case length. Related cases (meaning that one decision will substantially resolve all cases), if filed within a few weeks, may be consolidated. Waldfogel (1995) reports that plaintiffs can argue the case is related to another pending case and, if the judge agrees, the cases will be consolidated. A clerk reported $8 \%$ of filed cases were accepted as related in 1991 in SDNY. In another District Court, if a clerk identifies and two judges agree that a new civil case is related to another open civil case, they will be consolidated in the interests of justice or judicial economy. The clerk brings the possible connection to the attention of the judge of the new case, who then confers with the judge of the earlier case to determine whether they are in fact related cases. Consolidation would only occur for relatively high-frequency case types, which does not include eminent domain. For the handful of District cases that do overlap such that they are consolidated, we assume the decisions about case relatedness occur in a manner exogenous to judge assignment.

To instrument for $\mathbf{1}\left[M_{c t}>0\right]$, we define our District IV in two ways. Both definitions rely on the random assignment of District Court judges and the fact that some are more likely to be appealed than others. We use the first definition for data availability reasons, and 
we present the second definition if data were to become available in the future. In the first definition, $w_{c t}=\frac{\sum_{d=1}^{J} K_{c d t} *\left(\frac{L_{c d t}}{K_{c d t}}\right)}{\sum_{d=1}^{J} K_{c d t}}$, where $K_{c d t}$ denotes the number of cases filed in District court $d$ within Circuit $c$ at time $t$ ( $J$ goes from 5 to 13 depending on the District). $L_{c d t}$ denotes the number of judges with a particular characteristic assigned to cases. The intuition is that assigning District judges who are disproportionately appealed leads to an appeal in the Circuit, $\mathbf{1}\left[M_{c t}>0\right]$. Note that this assumes $K_{c d t}>0$. An approximation is to define $K_{c d t} *\left(\frac{L_{c d t}}{K_{c d t}}\right)$ as 0 if $K_{c d t}=0$. Then, the instrument can be constructed if $\sum_{d=1}^{J} K_{c d t}>0$, which holds for both physical and regulatory takings.

In the second definition, $\tilde{w}_{c t}=\sum_{\widetilde{d}=1}^{\tilde{J}} K_{c \widetilde{d t}} *\left(\frac{L_{c \tilde{d} t}}{K_{c \widetilde{d} t}}-E\left(\frac{L_{c \tilde{d} t}}{K_{c \widetilde{d} t}}\right)\right)$, where $\widetilde{d}$ denotes District courthouse or court. ${ }^{14}$ A District Court has several courthouses (also referred to as Divisions) and in some District Courts, random assignment is at the courthouse level. The second definition does not rely on the exogeneity of the location of takings controversies, $K_{c \widetilde{d}}$. It also does not rely on $K_{c \widetilde{d t}}>0$, though it still relies on $\sum_{\widetilde{d}=1}^{\tilde{J}} K_{c \widetilde{d t}}>0$. It is not possible to merge courthouse location for most of the District Court cases (we tried to link the courthouse information from the Administrative Office of the U.S. Courts database via the docket number). This results in $\tilde{w}_{c t}$ being undefined in over $50 \%$ of Circuit-years and thus requiring another dummying out for missing strategy. When we use $\tilde{w}_{c t}$, we include a dummy for missing values in $\tilde{w}_{c t}$ and define $\tilde{w}_{c t}$ to be 0 when it would otherwise be missing. In our main tables, we use $w_{c t}$, but in the Appendix we also report estimates that use $\tilde{w}_{c t}$ for robustness. The estimates are unaffected, which assuage concerns that the litigants' decision to appeal may respond to previous years' legal decisions.

The ideal construction of $\tilde{w}_{c t}$ takes a weighted sum across wheels of deviation from expectations, $E\left(\frac{L_{c \tilde{c} t}}{K_{c \tilde{d} t}}\right)$, separately for senior and non-senior judges. Senior judges can elect not to be assigned to certain wheels. Another District Court uses, instead of wheels, thirteen computer generated decks of cards-one deck for each case category and an identical number of cards (two or five) for each active judge 15 The decks refill when the majority of the deck has been exhausted. Senior judges can request to be assigned to certain decks. Even within a deck, senior judges can ex ante request a "bye" for specialized case types. Within each Dis14

Fact The Law of Iterated Expectations (LIE) implies $E\left(K_{c \widetilde{d} t} *\left(\frac{L_{c \tilde{d} t}}{K_{c \tilde{d} t}}-E\left(\frac{L_{c \tilde{d} t}}{K_{c \tilde{d} t}}\right)\right) * \epsilon_{c t}\right)=0$.

Proof Using LIE, $E\left(K_{c \widetilde{d} t} *\left(\frac{L_{c \tilde{d} t}}{K_{c \tilde{d} t}}-E\left(\frac{L_{c \tilde{d} t}}{K_{c \tilde{d} t}}\right)\right) * \epsilon_{c t}\right)=E\left(E\left[K_{c \widetilde{d} t} *\left(\frac{L_{c \tilde{d} t}}{K_{c \tilde{c} t}}-E\left(\frac{L_{c \tilde{d} t}}{K_{c \tilde{d} t}}\right)\right) * \epsilon_{c t} \mid K_{c \tilde{d} t}\right]\right)$. Rearranging results in: $E\left(K_{c \tilde{d} t} E\left[\left(\frac{L_{c \tilde{d} t}}{K_{c \tilde{d} t}}-E\left(\frac{L_{c \tilde{d} t}}{K_{c \tilde{d} t}}\right)\right) * \epsilon_{c t} \mid K_{c \tilde{d} t}\right]\right)$. Again by LIE: $E\left[\left(\frac{L_{c \tilde{d} t}}{K_{c \tilde{d} t}}-E\left(\frac{L_{c \tilde{d} t}}{K_{c \tilde{d} t}}\right)\right) * \epsilon_{c t} \mid K_{c \tilde{d} t}\right]=E\left[E\left(\left(\frac{L_{c \tilde{d} t}}{K_{c \tilde{d} t}}-E\left(\frac{L_{c \tilde{d} t}}{K_{c \tilde{d} t}}\right)\right) * \epsilon_{c t} \mid \epsilon_{c t}, K_{c \tilde{d} t}\right) \mid K_{c \tilde{d} t}\right]$. Rearranging once again: $E\left[\epsilon_{c t} E\left(\left(\frac{L_{c \tilde{d} t}}{K_{c \tilde{d} t}}-E\left(\frac{L_{c \tilde{d} t}}{K_{c \tilde{d} t}}\right)\right) \mid \epsilon_{c t}, K_{c \tilde{d} t}\right) \mid K_{c \tilde{d} t}\right]$. The expression $\frac{L_{c \tilde{d} t}}{K_{c \tilde{d} t}}-E\left(\frac{L_{c \tilde{d} t}}{K_{c \tilde{d} t}}\right)$ is the deviation of the ratio of judge assignment characteristics from the mean, so it should be independent of $\epsilon_{c t}$ and $K_{c \tilde{d} t}$. Therefore, $E\left(\left(\frac{L_{c \tilde{d} t}}{K_{c \tilde{d} t}}-E\left(\frac{L_{c \tilde{c} t}}{K_{c \tilde{d} t}}\right)\right) \mid \epsilon_{c t}, K_{c \tilde{d} t}\right)=0$.

${ }^{15} \mathrm{http}: / /$ www.mnd.uscourts.gov/cmecf/Order-for-Assignment-of-Cases.pdf 
trict Court are several courthouses (also referred to as Divisions). The appropriate Division is determined by where the parties are located and where the cause of action arose. Some Divisions get their own deck of cards. Taha (2009) reports that in 29 Districts, a case may be assigned to any judge in that District, while in the others, the cases are assigned to a geographic Division within the District and randomly assigned to one of the judges in that Division.

However, since $E\left(\frac{L_{c \tilde{d} t}}{K_{c \tilde{d} t}}\right)$ is uncomputable for senior judges since we would need to know the senior "byes" in every District courthouse, we drop senior District judges for calculating $\tilde{w}_{c t}$; we also drop visiting (judges routinely visit other courts to assist with caseload) and magistrate judges (they assist District Court judges but do not have life tenure and we do not have their biographical data) for similar reasons, collectively resulting in less than $10 \%$ sample loss. Non-ideological cases are referred to magistrate judges (Nash 2015), so omitting them will not matter. Identification is unaffected by dropping judges even if they are in the same wheel. Some courts spin separate random wheels for District judges and for magistrate judges. In some Districts, parties can decline assignment to a magistrate judge within a certain time period and request another random draw. This will not affect identification because it happens before the random assignment that we use. In some Districts, when the federal government is a litigant on the case, the U.S. attorney can pick the wheel. As stated earlier, we do not include cases where the federal government is litigant as those cases would go to the Federal Circuit.

Thus, conditional on case type, there is random assignment at the court or courthouse level, and we must only calculate the yearly expected composition of judges in District courthouses, $E\left(\frac{L_{c \tilde{d} t}}{K_{c \tilde{d} t}}\right)$, and we drop judges whose $E\left(\frac{L_{c \tilde{d} t}}{K_{c \tilde{d} t}}\right)$ is unknowable in the robustness check that uses $\tilde{w}_{c t}$.

Unlike for Courts of Appeals cases, we cannot use the random strings test as an omnibus assessment for violations of random assignment, because some Districts use rotational assignment or random drawing of judges from card decks without replacement. So we discuss the concerns qualitatively and suggest another empirical test. First, District Courts judges are revealed much earlier than Courts of Appeals judges. Ideally, we would use docket filings in the Administrative Office of the U.S. Courts pertaining to physical and regulatory takings, but judges are omitted for most cases prior to 2000, so we must use published District opinions to construct our District IV. So, we buttress the assumption that settlement, publication, and strategic use of keywords or citations are exogenous: 1) in District Courts, judges are much more constrained and ideology has been found to play hardly any role. Judicial ideology does not predict settlement rates (Ashenfelter et al. 1995; Nielsen et al. 2010), settlement fees (Fitzpatrick 2010), publication choice (Taha 2004), or decisions in published or unpublished cases (Keele et al. 2009) — this last fact is consistent with the District judge identity only affecting outcomes through the presence of an appeal but not through the Dis- 
trict Court decision, but this exclusion restriction is not necessary for the empirical analysis; 2) we examine these issues directly as follows.

Since the random strings test is ineffective for District Courts, we test whether District Court judicial biographical characteristics in filed cases jointly predict publication. We link PACER filing data, which has judge identity, to AOC data, which has information on publication. We obtained all freely available PACER (Public Access to Court Electronic Records) data on District cases from 32 districts for 1980 to 2008 for a total of 359,595 non-duplicated cases. This data contains the name of the District where the case was filed, the filing and termination date (missing for 10\% of cases), the assigned docket number, and the name of the District or magistrate judge presiding on the case. We merge the names of the judges into the Administrative Office of the U.S. Courts (AOC) database. We use LASSO to select biographical characteristics and no characteristic was chosen. We assume that remaining deviations from random assignment, like vacation days, are ignorable.

In sum, what is the difference between pro-government vs. pro-property owner precedent and the difference between pro-government vs. no precedent? The U.S. Federal Courts effectively randomize both the coin flip (pro-government vs. pro-property owner; what if Goldstein $v$. Pataki had been decided in favor of the property owners?) and the presence of the coin itself (pro-government vs. no decision vs. pro-property owner; what if Goldstein v. Pataki did not exist?). They do so because the District Court judges are also randomly assigned, which identifies an exogenous component of the presence of an appeal. However, our paper is primarily interested in the coin flip itself rather than the presence of the coin, which is addressed and analyzed in far more detail in Chen et al. (2014b), so we devote little space to discussing the latter in the results that follow.

3.4.7 Many Instruments A large number of biographical characteristics serve as valid instruments, which would result in a weak instruments problem if we used them all. Roughly thirty characteristics that enter in levels (Democrat, male, racial minority, black, Jewish, Catholic, No religion, Mainline Protestant, Evangelical, bachelor's degree (BA) received from same state of appointment, BA from a public institution, JD from a public institution, having an LLM or SJD, elevated from District Court, decade of birth (1910s, 1920s, 1930s, 1940s, or 1950s), appointed when the President and Congress majority were from the same party, ABA score, above median wealth, appointed by president from an opposing party, prior federal judiciary experience, prior law professor, prior government experience, previous assistant U.S. attorney, and previous U.S. attorney), judge-level interactions (e.g., racial minority Democrats), and panel-level interactions (e.g., fraction of judge seats assigned to Democrats multiplied by fraction of judge seats assigned to racial minorities) yielding a total of several thousand possible instruments.

There are two ways to reduce dimensionality: a priori theory and model selection. LASSO (least absolute shrinkage and selection operator) is commonly used for model selection (Bel- 
loni et al. 2012). LASSO has sparseness and continuity, which OLS lacks. With OLS, large subsets of covariates are deemed important, resulting in too many instruments, which makes 2SLS susceptible to a weak instruments problem. Small changes in the data result in different subsets of covariates deemed important. Formally, LASSO modifies OLS by adding a data penalty for having too many large coefficients. The model minimizes the sum of squares subject to the sum of the absolute value of the coefficients being less than a constant, which tends to set some coefficients to exactly 0 and hence reduces model complexity.

The larger the set of IV candidates, the more severe the LASSO penalty. Reducing the number of biographical characteristics by removing candidates that are over $99 \%$ correlated with one another increases the possibility of selecting candidates. Candidate instruments must have scores that satisfy a central limit theorem to reduce the chance that LASSO picks up spurious signals. Dropping candidate instruments that deviate from its modal value $e^{16}$ with less than $5 \%$ frequency yields another threshold choice. We compare results with and without LASSO model selection in Appendix Tables 4 to 8. We also report results from LIML (limited information maximum likelihood), which is weak-instruments robust and uses all the instruments.

In Appendix Table 8, we report the use of the Dantzig selector that accounts for correlation in the IV candidates and thus results in a less severe penalty. We also employ the following sensitivity check. With many endogenous variables and many instruments, there is a danger of overfitting with instruments from the wrong year. In robustness checks, we use the contemporaneous instruments to predict $L a w_{c(t)}$ and $\mathbf{1}\left[M_{c t}>0\right]$ and use the fitted values as instrumental variables in $2 \mathrm{SLS} 17$

Chen et al. (2014b) develops another solution. It presents a visual Hausman test, which can also be analogized to partial identification or set identification: the 2SLS results are visually presented for a variety of instruments that have a strong first stage. It also proposes, implements, and compares a solution that omits $\mathbf{1}\left[M_{c t}>0\right]$ altogether by defining $L a w_{c(t-n)}$ as the average of $-1 / 0 /+1$ (pro-property owner/no precedent/pro-government decisions). This robustness check (also reported in Appendix Table 8) imposes the additional identification assumption - that pro-property owner and pro-government owner decisions have opposite ef-

\footnotetext{
${ }^{16}$ The modal value is typically 0 .
}

${ }^{17}$ To see how, suppose:

$$
Y_{i c t}=\beta_{10} L a w_{c(t)}+\beta_{11} L a w_{c(t-1)}+\ldots+\varepsilon_{i c t}
$$

Let the first stage be: $L_{c(t)}=Z_{0} \Pi_{0}+u_{0}$, where $Z_{0}=\left[p_{c(t)}\right]$ and $L_{c(t-1)}=Z_{1} \Pi_{1}+u_{1}$, where $Z_{1}=$ $\left[p_{c(t-1)}\right]$. Set $\hat{X}=\left[\begin{array}{llll}\hat{L}_{c(t)} & \hat{L}_{c(t-1)} & \ldots & \hat{L}_{c(t-j)}\end{array}\right]$ for $j=0,1, \ldots$, where $\hat{L}_{c(t-j)}=Z_{j} \hat{\Pi}_{j}=Z_{j}\left(Z_{j}^{\prime} Z_{j}\right)^{-1} Z_{j}^{\prime} L_{c(t-j)}$ Observe that $\hat{\beta}=\left(\frac{\hat{X}^{\prime} X}{n}\right)^{-1} \frac{\hat{X}^{\prime} Y}{n}=\beta+\left(\frac{\hat{X}^{\prime} X}{n}\right)^{-1} \frac{\hat{X}^{\prime} \varepsilon}{n}$. Let $\hat{Q}=\left(\frac{\hat{X}^{\prime} X}{n}\right)$, then $\sqrt{n}(\hat{\beta}-\beta)=\hat{Q}^{-1} \frac{\hat{X}^{\prime} \varepsilon}{\sqrt{n}} \cdot \frac{1}{\sqrt{n}} \hat{X}_{j}^{\prime} \varepsilon=$ $\frac{1}{\sqrt{n}} \frac{X_{j} z_{j}}{n}\left(\frac{z_{j}^{\prime} z_{j}}{n}\right)^{-1} z_{j}^{\prime} \varepsilon=\hat{\Gamma} \sqrt{n} \frac{z_{j}^{\prime} \varepsilon}{n}$. Since $\sqrt{n} \frac{z_{j}^{\prime} \varepsilon}{n} \rightarrow N\left(0, \Phi_{j}\right)$, so $\sqrt{n}(\hat{\beta}-\beta) \rightarrow N(0, V), V=Q^{-1} \Gamma \Phi \Gamma Q^{-1}$. 
fects of equal size in absolute value. Our main specifications do not impose this identification assumption.

\section{Results}

\subsection{First Stage: The Effect of Judge Identity on Court Decisions The Republi-} can party has traditionally been associated with business interests, which favor growth over inequality, and libertarian interests, which disfavor government intrusion. These conflicting perspectives complicate political lines on eminent domain. Simply being Republican or Democrat does not predict eminent domain votes, which Sunstein et al. (2006) document and we confirm. However, Republican former federal prosecutors have litigated on behalf of the government and represent business and government interest, and they were 18 percentage points more likely to uphold a physical taking from 1958-2008. Racial minority Democrats have worked for the NAACP, a civil rights organization that advocates for racial minorities and backed private property rights, and they were 20 percentage points more likely to strike down a physical taking. These estimates are reported in Table 2 Columns 1 and 2. The number of observations slightly differ because data on whether a judge was a former federal prosecutor (U.S. Attorney) is sometimes missing.

In Column 3, we examine this relationship at the panel-level and include both biographical characteristics in the specification. An additional minority Democrat on one of the 134 three-judge panels decreased the chances of a pro-government decision by 19 percentage points while an additional Republican former federal prosecutor increased the chances of a pro-government decision by 23 percentage points. The similarity in point estimates with Columns 1 and 2 is consistent with their presence being pivotal. In Column 4, we examine this relationship at the Circuit-year level for the 107 Circuit-years with at least 1 case. The estimates indicate that an additional minority Democrat on a three-judge panel reduced the proportion of pro-government decisions by 21 percentage points, while an additional Republican former federal prosecutor increased the proportion of pro-government decisions by 31 percentage points.

At this point in the table, we should expect some sensitivity across columns because the effect of judge identity is analyzed at different levels of data aggregation in order to build intuition. In particular, the Circuit-year level estimates differ from the case level since cases are not evenly distributed across Circuit-years. For an example, suppose that there are 4 cases, one case each with $0,1,2$, or 3 judges who are minority Democrat, and suppose that the panel makes a pro-taking decision when there are 3 Republican former federal prosecutors. If 1 Circuit-year has the case with 3 minority Democrats and the other Circuityear has the remaining 3 cases, the coefficient at the Circuit-year level is $0.5(0.5=$ difference in percent pro-government/difference in minority Democrats assigned per seat) but when the 1 Circuit-year has the case with 2 minority Democrats, the coefficient at the Circuit-level is 1.5 . 
In Column 5, we control for Circuit and time fixed effects, the expected proportion of minority Democrats and Republican former federal prosecutors, and a dummy indicator for whether there were cases, $1\left[M_{c t}>0\right]$. The number of observations increases to the complete time-frame of 402 Circuit-years. The Eleventh Circuit was not founded until 1981, so the Eleventh Circuit has 6 fewer observations than the other Circuits. The Eleventh Circuit was created by splitting it off from the Fifth Circuit; Fifth Circuit decisions before this split are considered binding precedent in the Eleventh Circuit. We account for this split in our analyses by assigning pre-1981 precedent in the Fifth Circuit to observations in the Eleventh Circuit.

The point estimates are essentially unaffected by these controls, and this stability is important. This stability indicates that the variation in Takings Clause jurisprudence is due to the assignment of these judges and not fixed characteristics of the Circuit or time period nor characteristics of the pool of judges available to be assigned. The F-statistic increases slightly due to the controls, since the controls are predictive of the independent variable (this can be seen in Figure 3), and the increase is not due to the increase in sample size from dummying out for missing values. Redefining $L a w_{c t}=L a w_{c t} * \mathbf{1}\left[M_{c t-n}>0\right]$, i.e., defined to be 0 when $\mathbf{1}\left[M_{c t-n}>0\right]=0$, and regressing it onto the instrument $p_{c t}=\frac{N_{c t}}{M_{c t}} * \mathbf{1}\left[M_{c t-n}>0\right]$, while including $\mathbf{1}\left[M_{c t-n}>0\right]$ as a control, neither affects the coefficient nor the F-statistic on the joint significance of the biographical characteristics. Dummying out for missing values is standard in the literature. The joint F-statistics of the two biographical characteristics are above the weak instruments threshold.

When we weight our estimates by the number of cases in a Circuit-year, where weights are the geometric mean of $M_{c(t-n)}+1$ over the distributed lag, the statistical significance of the results increases. We also show in Appendix Table 8 that our results have strong Anderson-Rubin weak instruments-robust test statistics. We did not consider the solution employed in Galasso et al. (2015), which uses the predicted estimate from the first stage as the final instrument. Doing so would greatly increase the F-statistics, and Angrist and Pischke (2008) suggests to avoid doing so in order to not obtain identification from functional form assumptions. Thus, the first stage results should be interpreted as conservative estimates in terms of statistical significance relative to these alternative methods.

Columns 6 and 7 report the first stage analyzed at the Fiserv-level. The coefficients differ from those in Columns 4 and 5 because the Circuits do not contain the same number of zip codes. Notably, the joint F-statistics of the two biographical characteristics are substantially above the weak instruments threshold. The coefficients are similar moving from Column 6 to 7 , re-confirming that we identify exogenous variation in Takings Clause jurisprudence due to the assignment of these judges and not fixed characteristics at the Circuit or year level nor characteristics of the pool of judges available to be assigned. Also, our inclusion of $1\left[M_{c t}>0\right]$ and dummying out for missing values do not bias our coefficients. 
To check whether our linear specifications miss important aspects of the data, Figure 4 presents nonparametric local polynomial estimates of the first stage. Estimation proceeds in two steps. In the first step, we regress the proportion of decisions that were pro-government on Circuit and year fixed effects and we regress the instrument on the same. Next, we take the residuals from these two regressions and use a nonparametric local polynomial estimator to characterize the relationship between the instrument and pro-government decisions. Figure 4 shows there is no flat relationship throughout the distribution. These figures also show the tremendous variation across Circuits and years, which will be useful in estimating the impact of $L a w_{c t}$.

While there is a large literature on physical takings, there is less on regulatory takings. Since we have less by way of prior literature to guide us in determining biographical characteristics that affect regulatory takings decisions, we employ LASSO in selecting the Circuit-level instruments. There is also relatively little literature on the appeal of takings decisions, so we also employed LASSO at the District level. The LASSO-selected instruments for District IVs are: (i) Born in 1920s and attended public institution for baccalaureate (BA) and (ii) Evangelical * Born in 1940s with an F-statistic of 27.56 for Fiserv (Zip-Year); (i) Born in 1920s and attended public institution for BA and (ii) Born in 1920s and above median wealth with F-statistic of 9.15 for GDP (State-Year); and (i) Born in 1920s and attended public institution for BA and (ii) Black Prior Law Professor with F-statistic of 29.00 for CPS (Individual-Year). It is to be expected that the LASSO choice of instruments would slightly differ since the time-frame of the data, level of aggregation, and weighting differs slightly across outcome datasets. In any event, as we will see, employing both the District and Circuit IV renders similar results as to employing only the Circuit IV.

4.2 Economic Growth: Property Prices and GDP Figure 6 displays our central results - the effect of having pro-government Takings Clause jurisprudence on property prices and GDP - and the central falsification test. In property prices, growth is $2 \%$ points higher two years after pro-government takings precedent than after pro-property owner precedent. In GDP, growth is $1 \%$ point higher two years after pro-government takings precedent than after pro-property owner precedent. Null effects are displayed in the left-side of each pair of graphs. The null effects assure that the growth effects of Takings Clause jurisprudence are not due to secular trends in growth before the court decisions. The null effects are expected since randomly assigned judges do not affect property prices and growth before they are assigned.

Table 3 reports the average effect of pro-government Takings Clause jurisprudence over the subsequent four years. In property prices, it is $1.2 \%$ points $(p<0.01)$ while in GDP, it is $1.1 \%$ points $(p<0.01$ ) (Panel A Column 2 ). The lead effects are an insignificant $0.3 \%$ points and $0.2 \%$ points (Panel B Column 2). Column 1 reports OLS estimates, where the lag effects are smaller and insignificant, while the lead effects are similar to the lead effects 
when instrumented. Downward bias in OLS estimates occur when judges make pro-takings decisions when there is urban blight. Notably, the estimates are similar when instrumenting for $\mathbf{1}\left[M_{c t}>0\right]$ (Column 3).

Furthermore, the addition of Circuit-specific time trends (Table 4), removing Circuit and year fixed effects, clustering standard errors at the state level, controlling for the expected seat assignments to minority Democrats and Republican former federal prosecutors, weighting the data using population weights, and dropping one Circuit at a time affect neither the size nor significance of the impacts. Table 5 presents the full set of distributed lag coefficients underlying the estimates of Table 4. They consistently show that the effects rise after the first year and are strongest in the second year after the decision as seen in Figure 6. We also checked robustness to lagged dependent variables, wild bootstrap (Appendix Table 3), and clustering standard errors at the Circuit-year level.

The lower half of Table 5 shows that adding or subtracting a lag or two makes little difference. Estimates are also robust to specifications containing 10 years of lags. Notably, since the lags do not sum to 0, we observe growth rather than level effects. Panel B presents a specification with four leads and 1 lag. The magnitudes of the leads are small and insignificant as seen in Figure 6.

The larger effects on house prices than on GDP in Figure 6 are consistent with house prices increasing due to over-investment or being more forward-looking relative to contemporaneous variables like GDP. All estimates are subject to the usual caveats that causal effects are sufficient, but not necessary conditions for an outcome (Deaton 2010). To illustrate, Chen et al. (2016a) use a machine learning approach to analyze the effects of court laws and finds that, of 18 factors that predict abortion attitudes, the court variables comprise $25-30 \%$ of the sixth factor.

4.2.1 Further Robustness Note that Takings Clause jurisprudence has a growth impact when the data is collapsed to 1 experimental subject per Circuit-year. Appendix Tables 4 and 5 collapse the data to the Circuit-year level using population weights. Appendix Table 4 Column 6 shows that the average lag effect on property price growth is $1.3 \%$ points $(p<0.01)$. The lead effect is an insignificant $0.6 \%$ points. Appendix Table 5 Columns 6 shows that the average lag effect on GDP growth is $1.2 \%$ points $(p<0.01)$ and the lead effect is an insignificant $0.2 \%$ points. Columns $7-9$ of the tables show the results with alternative specifications, where LASSO is used to instrument for $L a w_{c t}$ and $\mathbf{1}\left[M_{c t}>0\right]$ (Belloni et al. 2012). Columns 1-5 show the results using the full data. The tables in the main text report Columns 1-3, as standard in the literature (Bertrand et al. 2004).

The estimates have similar size and significance as in the non-collapsed data. Appendix Tables 4 and 5 lower half calculate the typical effects of Law taking into account how many cases typically occur. The conditional effect refers to an effect conditional on a case being in front of a judge. It is a scaling of $\beta_{1}$. The unconditional effect includes the ef- 
fect of the presence of a case, $\beta_{2}$. To compute the effect of pro-government precedent in a typical Circuit-year, multiply the coefficient on $L a w_{c t}$ by $\mathbf{E}\left[L a w_{c t} \mid \mathbf{1}\left[M_{c t}>0\right]\right]$, the typical proportion of decisions that are pro-government when there are Circuit cases, and by $\mathbf{E}\left[\mathbf{1}\left[M_{c t}>0\right]\right]$, the proportion of Circuit-years with a Circuit case. To calculate the typical effect of pro-government precedent taking into account the presence of an appeal: $\mathbf{1}\left[M_{c t}>0\right]^{*} \mathbf{E}\left[\mathbf{1}\left[\right.\right.$ Progovernment $\left.\left._{c t}>0\right]\right]+$ Law $_{c t} * \mathbf{E}\left[\mathbf{1}\left[\right.\right.$ Progovernment $\left.\left._{c t}>0\right]\right]$.

Appendix Tables 6 and 7 report the same set of robustness checks for GDP as Tables 4 and 5 did for property prices. Appendix Table 8 reports similar estimates with further sensitivity checks. The instrument is $p_{c t}-\mathbf{E}\left(p_{c t}\right)$ rather than $p_{c t}$ conditional on $\mathbf{E}\left(p_{c t}\right)$, the LASSO penalty employs Dantzig selector to adjust for correlation among instrument candidates, judges are dropped when we lack information about their expected assignment probability, and separate first-stages are implemented to reduce over-fitting. Notably, the Dantzig selector chooses minority Democrats and Republican prior U.S. Attorneys as instruments. Columns 4-5 define $L a w_{c t}$ as the average of: +1 : pro-takings and -1: pro-property owner.

4.2.2 Sectoral Impacts Table 12 provides prima facie evidence on the mechanisms. Physical takings jurisprudence that increased government power of eminent domain spurred annual growth in the government sector by $0.3 \%$ points $(p<0.01)$, the transportation and utilities sector by $1.4 \%$ points $(p<0.01)$, and the construction sector by $3.9 \%$ points $(p<0.01)$, as we expect with public infrastructure (Panel C Column 1). Eminent domain power also contributes to annual growth in the sectors of agriculture by $5.7 \%$ points $(p<0.01)$; retail by $1.7 \%$ points $(p<0.01)$; and finance, insurance, rental, and estate by $2.2 \%$ points $(p<0.05)$. Growth in the service sector is adversely affected by $9.2 \%$ points $(p<0.01)$.

Since the effects are observed outside of the government, transportation, and construction sectors, we can be confident that the impact of Takings Clause jurisprudence is not due to the local effect of allowing or disallowing a takings to proceed but due to the precedent that gives more latitude to reassign property rights. That is, while some of these differences are mechanical (allowing a physical takings to proceed directly leads to government spending, property development, and GDP growth as an accounting matter), these sectoral results suggest that the precedent set by the decision is more important than the decision on the litigated government taking. Table 12 also reports calculations of typical effects. Statistical significance come from the estimates of the coefficients, so significance tests are not repeated to save space.

4.2.3 Local Impacts This inference is further supported in Table 5 Panel C. We use zip code-level data to distinguish the local effect of eminent domain decisions affirming or overturning a local taking from the precedential effect of making it easier for subsequent takings. For example, following Midkiff, which allowed Hawaii to condemn property because an oligopoly in land ownership was "injuring the public tranquility and welfare," prices 
doubled within six years in the locality (Kanner, 2009, Roth, 1992).

$$
\begin{aligned}
& g_{i c t}=\theta_{c}+\theta_{t}+\sum_{n=0}^{L} \beta_{7 t-n} \text { Law }_{c t-n}+\sum_{n=0}^{L} \beta_{8 t-n} 1\left[M_{c t-n}>0\right]+ \\
& \sum_{n=0}^{L} \beta_{9 t-n} \text { LocalLaw }_{i c t-n}+\sum_{n=0}^{L} \beta_{10 t-n} \mathbf{1}\left[\text { LocalM }_{\text {ict-n }}>0\right]+\varepsilon_{i c t}
\end{aligned}
$$

We separately instrument $L a w_{c t}$ and LocalLawict using judicial assignment in cases that occur in zip code $i$ and in cases that occur in Circuit $c$. The effects of eminent domain cases are largely through their precedential power $(0.7 \%$ points compared to $1 \%$ point when not controlling for the local effects). We present every fourth quarter in the quarterly lags to save space, but the means are the mean for quarters 0-16.

\subsection{Economic Inequality: Racial Disparities and Displacement Government power}

of expropriation is perceived to have disparate impacts. Previous empirical studies also document that low-valued land is undercompensated (Munch 1976, Chang 2010). Urban renewal efforts have displaced hundreds of thousands of families and tens of thousands of businesses Garnett 2006). Racial minorities are not employed in the same numbers as those whose homes or businesses are displaced by eminent domain. Poletown Neighborhood Council v. City of Detroit awarded General Motors property, but it subsequently employed fewer people than the combined employment of displaced businesses (Somin 2004). We use race to proxy for inequality because of its salience (Semuels 2016) and because unobservables are not rank-invariant to potential treatment status, so quantile regressions by price and income are inappropriate. In particular, the same parcels that have relatively lower property prices without pro-government precedent would not be the ones that would have relatively lower property prices with pro-government precedent.

To the best of our knowledge, the only quantitative study on the distance that individuals move when displaced through eminent domain, is a Canadian study showing that over half move less than 3 miles when displaced and 99\% move less than 15 miles (Sherwood, 1975). Qualitative studies report that gentrification-which may or may not include eminent domainled to displaced persons moving within the same city rather than to a different city LeGates and Hartman 1982).

4.3.1 Displacement and Housing Every year, 10\% of Americans make within-county moves and 6\% make out-county moves, according to the March CPS. Using this data (which asks whether an individual moved within the county in the last year, whether an individual moved outside the county in the last year, whether an individual lives in public housing, and whether an individual lives below the poverty line) we find that pro-government physical takings precedent increase within-county moves of racial minorities by $0.1 \%$ more than they do of whites (Table 6). This difference is statistically significant at the $1 \%$ level. Non-whites are no more likely to make moves from outside the county than whites after pro-government 
takings decisions. Whites were $0.2 \%$ more likely to make within-county moves and $0.007 \%$ more likely to make out-of-county moves after pro-government takings decisions. No effect is found before the decision (Panel B). A previous draft presents further analysis on the impact on racial inequality. Racial minorities also became $0.3 \%$ more likely to live in public housing and $0.7 \%$ more likely to live below the poverty line.

4.3.2 Employment Every year, $74 \%$ of whites are employed and $66 \%$ of non-whites are employed. ${ }^{18}$ Table 7 reports that eminent domain power increased employment overall, which is consistent with improved economic growth; to calculate: multiply the non-interacted average lag effect by 0.78 (the proportion white) and add the interaction effect multiplied by 0.22 (the proportion non-white). However, racial disparities increased as minorities were 1.7-2.1\% less likely to be employed than whites $(p<0.01, p<0.05)$ (Table 7 Panel A Columns 2-3).

4.3.3 Condemnations With increased power of expropriation, we should see government actors acquiring more parcels, providing less compensation per parcel, or taking more expensive property. In some jurisdictions, eminent domain is not authorized for residential properties (Berliner and Coalition 2006). Business owners have noted that re-establishment expenses are insufficient to cover increased rent and remodeling expenses associated with displacement (Garnett 2006). Communities have reported concerns about job loss and trouble attracting new businesses after the number of evicted businesses jumped from 39,000 in 1963 to 100,000 in 1971 (Frieden and Sagalyn 1991).

We examine state condemnations for federally funded transportation projects to measure the behavioral response to government power of expropriation. Variables include: 1) aggregate compensation for all parcels acquired per state-year whether through open market purchase, condemnation, or administrative settlement; 2) aggregate parcels acquired per state-year; 3) displacement and relocation costs ${ }^{19}$ When courts are more likely to uphold a taking, we may see governments exercising increased power of expropriation.

We find that land parcels are taken more frequently from businesses, despite their being more litigious and expensive to displace than residential tenants. Table 8 reports that land parcels were taken $12 \%$ more frequently from businesses $(p<0.01)$, but $7 \%$ less frequently from residences $(p<0.05)$. Relocation costs of displaced business were $16 \%$ higher $(p<0.01)$, but lower for displaced residences $(p<0.01)$. Because of the shift in the type of parcel taken, compensation increased by $12.5 \%(p<0.01)$ and number of parcels decreased by $10.3 \%$ $(p<0.01)$. These estimates vary in magnitudes across specifications as they are estimated in levels due to the time frame of the available data. No lead effects are found.

\footnotetext{
${ }^{18}$ These percentages come from MORG CPS. As standard in the literature, individuals who are unemployed or not-in-labor force are counted as "not employed".

${ }^{19}$ Displaced entities are eligible to receive reimbursements for moving and relocation expenses and the added costs of becoming reestablished at the new location (separately for residential and commercial tenants).
} 
4.3.4 Highways Our highway data includes 2-digit highways (rays away from MSAs that connect central business districts with regions outside the central city), 3-digit highways (circles around MSAs that primarily serve urban areas), 2-digit federal highways (interstate between MSAs), and planned highways. Table 9 shows that government power of expropriation increased highway construction. Highway rays increased by $4 \%$ points $(p<0.1)$, highway circles by $0.7 \%$ points $(p<0.01)$, and planned highways by $3.3 \%$ points $(p<0.05)$. Interstate highways did not increase significantly, but since interstate highways connect across Circuits, the effects will be muted because Circuits face different treatments. Notably, the broad-based growth across sectors in Table 12, especially for agriculture, is consistent with the increase in highway rays connecting rural areas with central business districts.

\section{Mechanisms}

Even though the differences in government and economic activity seem to be aligned with the differences in judges' revealed preferences (some judges prioritize growth and economic efficiency, while others prioritize equality and fairness), the results we have discussed so far could potentially be attributed to other characteristics of eminent domain power. Expropriation need not be total, but could be partial such as zoning, environmental regulation, or flooding. In the U.S., this is called a regulatory taking and also is influenced by physical takings precedent. One recent study finds that rezoning six neighborhoods increased total employment by $12-21 \%$ and weekly wages by $8-13 \%$, amounting to $\$ 269$ million per year (Busso et al. 2013).

5.1 Impact of Regulatory Takings Tables 11 and 12 report the effect of one dimension of eminent domain power-the precedential effects of regulatory takings jurisprudence. The full list of cases is displayed in Appendix Table 9. Table 11 reports the average effect of pro-government regulatory takings jurisprudence over the subsequent four years. It is $0.2 \%$ points in property prices $(p<0.01)$ and GDP $(p<0.05)$ (Panel A Column 2). The lead effects are insignificant (Column 2). In contrast to physical takings precedent, there are no significant effects on racial disparities in within-county moves or employment status (Panel B) and no significant effects on displacements for federal transportation projects or highway construction (Panel C). Panel D verifies that these results are not due to weak instruments. Regulatory takings precedent is more frequent than physical takings precedent, so the scaled effects taking into account the typical jurisprudence per Circuit-year yields similar effects of both sets of jurisprudence (Table 12 Panels A and B). Table 12 Panel A reports typical effects for physical takings jurisprudence and Panel B for regulatory takings jurisprudence. Statistical significance come from the estimates of the coefficients so are not repeated to save space.

Regulations do not necessarily lead to property development, and the construction or transportation and utilities sectors were not significantly affected (Table 12 Panel C). However, pro-government regulatory takings precedent increased growth in the sectors of gov- 
ernment by $0.04 \%$ points $(p<0.05)$, services by $3.8 \%$ points $(p<0.01)$, finance, insurance, rental, and estate by $0.3 \%$ points $(p<0.01)$, sectors associated with white-collar industries. It decreased growth in the sectors of manufacturing by $0.9 \%$ points $(p<0.01)$ and wholesale by $0.6 \%$ points $(p<0.05)$.

5.2 Perceived Takings Risk and Investment TOT may be further broken down between direct precedential and indirect expressive effects Sunstein 1996; Chen and Yeh 2013, 2014b). Government actors are instructed to keep abreast of the latest laws, but investors may only hear about laws indirectly. Simply hearing about a legal decision can shift people's preferences and experienced utility (Chen and Yeh 2014a) and mobilize individuals to donate to campaigns (Chen et al. 2014b). Newspaper accounts of prominent decisions, such as Kelo v. City of New London, made ordinary citizens feel vulnerable (Nadler et al. 2008).

We randomly expose data entry workers to newspaper articles summarizing Courts of Appeals eminent domain decisions and assess whether perceived takings risk responds to eminent domain decisions. The methodology is provided in more detail elsewhere Chen and Horton 2014; Shaw, Horton and Chen 2011; Chen 2011; Manski 2004). For eminent domain, we ask whether legal decisions shift stated expectations. We hired 266 workers to enter data. After completing the lock-in task (all workers completed 3 paragraphs involving Tagalog translations of Adam Smith's The Wealth of Nations), workers in each of 4 treatment groups and 1 control group were asked to transcribe abbreviated newspaper summaries of an eminent domain decision that was either a regulatory or physical takings decision and either a pro-government or pro-property owner outcome. The control group proceeded immediately to the perceived takings risk question:

"What do you think is the probability that the government will deny you the right to use your property (land or house or any other physical property) in a way that you want? Provide a number from 0-100. A higher number indicates more certainty that the government will deny you your right."

We paid subjects 10 cents to complete each paragraph; a paragraph takes about 100 seconds to enter, so the offered payment was equivalent to $\$ 28.80$ per day. To compare, the U.S. federal minimum base wage for tipped waiters is $\$ 2.15 /$ hour $(\$ 17.20$ per day) and the federal minimum wage is $\$ 7.25 /$ hour $(\$ 58 /$ day). The exact paragraphs follow below. Original newspaper articles are available on request.

1 of 3 Lock-in Tasks: Kaya sa isip o diwa na tayo ay sa mga ito, excites ilang mga antas ng parehong damdamin, sa proporsyon ng kasiglahan o dulness ng kuru-kuro. Ang labis na kung saan sila magbuntis sa kahirapan ng mga wretches nakakaapekto sa partikular na bahagi sa kanilang mga sarili ng higit pa sa anumang iba pang; dahil sa takot na arises mula sa kathang isip nila kung ano ang kani-kanilang mga sarili ay magtiis, kung sila ay talagang ang wretches kanino sila ay naghahanap sa, at kung sa partikular na bahagi sa kanilang mga sarili ay talagang apektado sa parehong miserable 
paraan. Ang tunay na puwersa ng mga kuru-kuro na ito ay sapat na, sa kanilang mga masasaktin frame, upang gumawa ng na galis o hindi mapalagay damdam complained ng.

Regulatory Pro-Property owner (Hamilton Bank of Johnson City v. Williamson Cty Reg. Planning (1984)): A local developer had received preliminary approval to develop houses on his land in the Northern section of Williamson County, Tennessee. After the developer had incurred substantial costs and developed most of the subdivision, the county changed its zoning ordinance. Hamilton Bank bought the remaining acres of undeveloped land through foreclosure sale. It reapplied for permission to build the full complement of houses, which the planning commission denied because of the new zoning regulations. Claiming that the commission's denial amounted to a taking of its property in violation of the Fourteenth and Fifteenth Amendments to the Constitution, Hamilton Bank argued before a District jury court that zoning regulation had rendered the land economically useless, and it would lose at least $\$ 1$ million because profits from the reduced number of houses would not even cover the costs of developing the land. The District Court found the commission's regulations violated the Just Compensation Clause of the Fifth Amendment, and awarded the bank $\$ 30,000$. The US Court of Appeals upheld the argument.

Regulatory Pro-Government (Rector, Wardens 8 Members of Vestry of St. Bart's Church (1990)): The Federal Court of Appeals upheld the landmark designation of St. Bartholomew's Church in New York City against a constitutional challenge by the Episcopal Parish. The parish argued that landmark status interfered with its property rights. The church had applied for permission to demolish its landmark Community House, to make way for a new office tower, income from which would support church activities. However, in affirming a judgment by a lower court, the Second Circuit Court states that the New York City Landmarks law did not violate the Church's Fifth Amendment right against government takings of property without just compensation, because the church had failed to prove that it could not continue its religious practice in its existing facilities.

Physical Pro-Property owner (Hall v. City of Santa Barbara (1986)): The U.S. 9th Circuit Court of Appeals ruled that a Santa Barbara's mobile home rent control ordinance may violate the U.S. Constitution by giving tenants an interest in landlord's property without just compensation for the landlords. The ordinance requires mobile park operators to offer their tenants leases of unlimited duration, where the tenant may end the lease at will but the mobile home operator only for a cause narrowly defined in the ordinance. Rent increases are also strictly limited. William and Jean Hall, owner of Los Amigos Mobile Home Estates, a mobile home park within the City of Santa Barbara, challenged the ordinance on the ground it effected a taking of their property and that such taking was neither for a public purpose nor justly compensated.

Regulatory Pro-Government (Building Owners and Managers Ass'n Intern. v. F.C.C. (2001)): A federal appeals court here has ruled that property renters have a right to install direct-broadcast satellite dishes in locations under their control, even if such action is prohibited by a lease agreement with the landlord. Real estate owners had sought to control renters' ability to use their balconies and patios as dish-installation sites. The Building Owners and Managers Association claimed that the government's protection of renters' rights was against the Fifth Amendment prohibiting the taking of private property without just compensation. The court however, rejected the argument.

We found that subjects exposed to any eminent domain decision increased their self-reported takings risk by $10 \%$ relative to the control group that was not exposed to eminent domain decisions $(p<0.05)$. Figure 7 displays the distribution of responses for the control group and the treatment groups. Both OLS regressions and the Wilcoxon-Mann-Whitney test for 
differences in distributions indicate that $p<0.05$. Pro-property owner and pro-government decisions had no significant difference.

Recall that $\beta_{1}$ captures the effect of the heads-or-tails coin flip (pro-government vs. proproperty owner precedent), $\beta_{1}+\beta_{2}$ captures the effect of the heads coin flip and the presence of the coin (pro-government precedent vs. no decision), and $\beta_{2}$ captures the effect of the tails coin flip and the presence of the coin (pro-property owner precedent vs. no decision). Table 10 Panel $\mathrm{C}$ presents calculations of $\beta_{1}+\beta_{2}$ and their joint significance: $0.1-0.2 \%$ points for property prices $(p<0.01)$ and $\operatorname{GDP}(p<0.05)$.

In sum, these results suggest that the primary effects of Takings Clause jurisprudence is through addressing a failure of Coasean bargaining-the difference in legal precedent that expand or contract the actions that governments can take to reassign property rights, rather than shifts in expectations. A full discussion of $\beta_{2}$ is for another paper. In principle, we can separately identify the effect of the presence of a case from the effect of pro-property owner precedent in a high-frequency outcome dataset during the time window after a case is announced and before the case resolution.

\section{Conclusion}

Our paper contributes to a literature on the long-run consequences of institutions such as common law (Acemoglu et al. 2001; Dell 2010, La Porta et al. 1998), ongoing debates on whether institutions are mainly products of economic or social determinism (Rosenberg 1993; Klarman 2004), and whether accidents, leaders, and decisions have significant impacts on society (Banerjee and Duflo 2014).

We present a simple model of takings that clarifies competing views of the effects of government power of appropriation. It is frequently believed that a society that fails to protect property rights against governmental restriction also fails to support rule of law and economic growth (North and Thomas 1973, North and Weingast 1989, De Soto 2000). Our model suggests that making it easier for the government to take property rights, even with compensation, typically leads to lower economic growth because of distortion in investment incentives, unless the public use channel dominates. If there are no public use benefits and there is fair market compensation, a greater risk of takings has no effect on economic outcomes. Introducing under-compensation, a greater risk of takings leads to under-investment and lower property prices, and these investment distortions would invariably lead to lower economic growth. Positive growth effects would be due to the benefits of public projects.

U.S. Federal Court judges articulating government power to reassign property rights have important effects on government and economic activity. The effects of their decisions seem to be largely attributable to a shift in government and economic activity directly relevant to the preferences of the judges.

Minority Democrats assigned as judges under the Federal Court system decide eminent 
domain cases in a manner more closely linked to racial minorities' concerns: minorities have their property disproportionately taken and are undercompensated, and minority Democrats are 20 percentage points more likely to vote to protect property rights. Republican former federal prosecutors decide cases in a manner more closely linked to business and government interests, and they are 18 percentage points more likely to vote to uphold government takings.

Using data on all U.S. takings precedent in Courts of Appeals, we show that rulings making it easier to take physical property rights spur economic growth and property values, but increase racial inequality as minorities become more likely to be unemployed and displaced.

Consistent with shifts in legal standard and a subsequent increase in actual government activity, states displace larger and more expensive commercial tenants for federal transportation projects and increase highway construction. Property values in the local zip code(s) where the original takings occurred also increase. The economic growth impacts are concentrated in the sectors of construction, transportation and utilities, and government, as one would expect with physical takings, but also in agriculture, retail, and finance and real estate. In contrast to physical takings precedent, decisions making it easier to regulate without having to compensate affect neither condemnations for federal transportation projects nor racial inequality in employment status nor displacement. Economic growth effects are smaller and concentrated in the services, government, and finance and real estate sectors.

Decisions that expanded government power of expropriation increased government reassignment of property rights: local governments displaced larger and more expensive commercial tenants for federal transportation projects and highway construction increased. GDP and property values increased. But racial disparities also increased: minorities became more likely to move and be unemployed relative to whites. Furthermore, results remain virtually identical when including controls.

We show that interpreting the text in different ways impacted growth and inequality in a manner consistent with the "Reverse Robin Hood" concerns that the notion of public use has been instrumentalized to help the rich at the expense of the poor (Reinhart 2015). Moreover, these findings have implications beyond eminent domain policy. Policies that improve minorities' bargaining power and access to courts may ameliorate some of the disparate impacts of eminent domain.

Extrapolating these findings on government power of expropriation to other countries needs caution. In the U.S., executive power is relatively constrained by the judicial and legislative branches; moreover, there is a tradition of strong individual property rights, which can lead to potential hold-up problems. For example, a U.S. property owner owns the oil that is discovered under their own land, but the same is not true for most European countries. Spending on public projects, e.g., $95 \$$ billion is spent per year on place-based policies in the U.S. (Kline and Moretti 2014), may be more likely with government power of expropriation. Countries with potential for agglomeration, complementarities, fiscal multipliers, and 
transitions between steady states may also find large effects of eminent domain power. 


\section{References}

Abramowicz, Michael, Ian Ayres, and Yair Listokin, "Randomizing Law," University of Pennsylvania Law Review, March 2011, 159 (4), 929-1005.

Acemoglu, Daron, Simon Johnson, and James A. Robinson, "The Colonial Origins of Comparative Development: An Empirical Investigation," The American Economic Review, December 2001, 91 (5), 1369 1401.

Aguiar, Mark and Manuel Amador, "Growth in the Shadow of Expropriation," The Quarterly Journal of Economics, May 2011, 126 (2), 651-697.

Angrist, Joshua D. and Jörn-Steffen Pischke, Mostly Harmless Econometrics: An Empiricist's Companion, Princeton University Press, 2008.

Araiza, Alberto G., Daniel L. Chen, and Susan Yeh, "Does Appellate Precedent Matter? Stock Price Responses to Appellate Court Decisions on FCC Actions," in Yun chien Chang, ed., Empirical Legal Analysis: Assessing the Performance of Legal Institutions, Vol. 19 of Economics of Legal Relationships, Routledge, 2014.

Ash, Elliott, Daniel L. Chen, and Suresh Naidu, "The Effect of Conservative Legal Thought on Economic Jurisprudence," Technical Report 2016.

Ashenfelter, Orley, Theodore Eisenberg, and Stewart J. Schwab, "Politics and the Judiciary: The Influence of Judicial Background on Case Outcomes," Journal of Legal Studies, 1995, 24 (2), 257-281.

Badawi, Adam B. and Daniel L. Chen, "The Shareholder Wealth Effects of Delaware Litigation," Working Paper, ETH Zurich, Mimeo 2014.

Baliga, Sandeep, Eran Hanany, and Peter Klibanoff, "Polarization and ambiguity," The American Economic Review, 2013, 103 (7), 3071-3083.

Banerjee, Abhijit V. and Esther Duflo, "Under the Thumb of History? Political Institutions and the Scope for Action," Annual Review of Economics, 2014, forthcoming (6) (1).

_ Paul J. Gertler, and Maitreesh Ghatak, "Empowerment and Efficiency: Tenancy Reform in West Bengal," The Journal of Political Economy, April 2002, 110 (2), 239-280.

Barondes, Royce De Rohan, "Federal District Judge Gender and Reversals," in "5th Annual Conference on Empirical Legal Studies Paper" Working Paper 15 July 2010.

Barrios, Thomas, Rebecca Diamond, Guido W. Imbens, and Michal Kolesár, "Clustering, Spatial Correlations and Randomization Inference," Journal of the American Statistical Association, June 2012, 107 (498), 578-591.

Barro, Robert J., "Government Spending in a Simple Model of Endogeneous Growth," Journal of Political Economy, 1990, 98 (5), 103-125.

Barry, Nora, Laura Buchanan, Evelina Bakhturina, and Daniel L. Chen, "Events Unrelated to Crime Predict Criminal Sentence Length," Technical Report 2016.

Baum, Matthew A. and Tim Groeling, "Shot by the Messenger: Partisan Cues and Public Opinion Regarding National Security and War," Political Behavior, June 2009, 31 (2), 157-186.

Baum-Snow, Nathaniel, "Did Highways Cause Suburbanization?," The Quarterly Journal of Economics, 2007, 122 (2), 775-805.

Belloni, Alex, Daniel L. Chen, Victor Chernozhukov, and Chris Hansen, "Sparse Models and Methods for Optimal Instruments with an Application to Eminent Domain," Econometrica, November 2012, 80 (6), 2369-2429.

Berdejó, Carlos and Daniel L. Chen, "Priming Ideology? Electoral Cycles without Electoral Incentives among U.S. Judges," Working Paper, ETH Zurich December 2014.

Berdejo, Carlos and Daniel L. Chen, "Electoral Cycles Among U.S. Courts of Appeals Judges," Technical Report 2016.

Berliner, Dana and Castle Coalition, Opening the Floodgates: Eminent Domain Abuse in the Post-Kelo World, Castle Coalition, 2006.

Bertrand, Marianne, Esther Duflo, and Sendhil Mullainathan, "How Much Should We Trust Differences-In-Differences Estimates?," The Quarterly Journal of Economics, 2004, 119 (1), 249-275.

Besley, Timothy, "Property Rights and Investment Incentives: Theory and Evidence from Ghana," The Journal of Political Economy, 1995, 103 (5), 903-937.

- and Anne Case, "Unnatural Experiments? Estimating the Incidence of Endogenous Policies," The Economic Journal, November 2000, 110 (467), F672-F694.

Bird, Susan Willett, "The Assignment of Cases to Federal District Court Judges," Stanford Law Review, January 1975, 27 (2), 475-487.

Blume, Lawrence, Daniel L. Rubinfeld, and Perry Shapiro, "The Taking of Land: When Should 
Compensation Be Paid?," The Quarterly Journal of Economics, February 1984, 99 (1), 71-92.

Breyer, Stephen, Active Liberty: Interpreting Our Democratic Constitution, Vintage Books, 2006.

Buchanan, James M. and Yong J. Yoon, "Symmetric Tragedies: Commons and Anticommons," Journal of Law and Economics, 2000, 43 (1), 1-14.

Bullock, John G., "Elite Influence on Public Opinion in an Informed Electorate," American Political Science Review, August 2011, 105 (03), 496-515.

Busso, Matias, Jesse Gregory, and Patrick Kline, "Assessing the Incidence and Efficiency of a Prominent Place Based Policy," The American Economic Review, 2013, 103 (2), 897-947.

Byrne, J. Peter, "Condemnation of Low-Income Residential Communities Under the Takings Clause," UCLA Journal of Environmental Law and Policy, 2005, 25, 131-169.

Cao, Guangzhong, Changchun Feng, and Ran Tao, "Local "Land Finance" in China's Urban Expansion: Challenges and Solutions," China \& World Economy, 2008, 16 (2), 19-30.

Carpenter, Dick M. and John K. Ross, "Testing O'Connor and Thomas: Does the Use of Eminent Domain Target Poor and Minority Communities?," Urban Studies, 2009, 46 (11), 2447-2461.

Chang, Yun-Chien, "An Empirical Study of Compensation Paid in Eminent Domain Settlements: New York City, 1990-2002," The Journal of Legal Studies, January 2010, 39 (1), 201-244.

Chen, Daniel L., "Markets and Morality: How Does Competition Affect Moral Judgment?," Working Paper, Duke Law School October 2011.

,"The Deterrent Effect of the Death Penalty? Evidence from British Commutations During World

War I," Working Paper, ETH Zurich May 2013.

_ , "Can Markets Stimulate Rights? On the Alienability of Legal Claims," RAND Journal of Economics, Spring 2015, 46 (1), 23-65.

, "Priming Ideology: Why Presidential Elections Affect U.S. Courts of Appeals Judges," Technical Report 2016.

and David S. Abrams, "A Market for Justice: A First Empirical Look at Third Party Litigation Funding," Journal of Business Law, 2013, 15 (4), 1075-1109.

- and Holger Spamann, "This Morning's Breakfast, Last Night's Game: Detecting Extraneous Factors in Judging," Working Paper, ETH Zurich 2014.

and James J. Prescott, "Implicit Egoism in Sentencing Decisions: First Letter Name Effects with Randomly Assigned Defendants," 2016.

and Jasmin Sethi, "Insiders and Outsiders: Does Forbidding Sexual Harassment Exacerbate

Gender Inequality?," Working Paper, University of Chicago October 2011.

and Jess Eagel, "Can Machine Learning Help Predict the Outcome of Asylum Adjudications?,"

Technical Report 2016.

and Jo Lind, "Religion, Welfare Politics, and Church-State Separation," Journal of Ecumenical Studies, 2007, 42, 42-52.

and Jo Thori Lind, "The Political Economy of Beliefs: Why Fiscal and Social Conservatives and Liberals Come Hand-in-Hand," Working Paper July 2014.

and John J. Horton, "Are Online Labor Markets Spot Markets for Tasks?: A Field Experiment on the Behavioral Response to Wage Cuts," Management Information Systems Quarterly, 2014. (Revised and Resubmitted).

and Martin Schonger, "Social Preferences or Sacred Values? Theory and Evidence of Deonto-

logical Motivations," Working Paper, ETH Zurich, Mimeo August 2013.

and _ , "A Theory of Experiments: Invariance of Equilibrium to the Strategy Method of Elicitation and Implications for Social Preferences," Working Paper, ETH Zurich January 2015.

and Susan Yeh, "Distinguishing Between Custom and Law: Empirical Examples of Endogeneity in Property and First Amendment Precedents," William ES Mary Bill of Rights Journal, 2013, 21 (4), 1081-1105.

- and _ "The Construction of Morals," Journal of Economic Behavior and Organization, August 2014, 104, 84-105.

and _ "How Do Rights Revolutions Occur? Free Speech and the First Amendment," Working Paper, ETH Zurich December 2014.

— , Jens Frankenreiter, and Susan Yeh, "Measuring the Effects of Legal Precedent in U.S. Federal

Courts," Working Paper, ETH Zurich December 2014.

, Kristen Kwan, Maria Maass, , and Luisa Ortiz, "Law and Norms: Using Machine Learning

to Predict Attitudes Towards Women and Abortion," Technical Report 2016.

, Matt Dunn, Rafael Garcia Cano Da Costa, Ben Jakubowki, and Levent Sagun, "Early 
Predictability of Asylum Court Decisions," Technical Report 2016.

, Moti Michaeli, and Daniel Spiro, "Ideological Perfectionism on Judicial Panels," Working Paper, ETH Zurich January 2015.

, Tobias J. Moskowitz, and Kelly Shue, "Decision-Making Under the Gambler's Fallacy: Evidence from Asylum Judges, Loan Officers, and Baseball Umpires," Working Paper, ETH Zurich March 2015.

Variation in Abortion Jurisprudence," Working Paper, ETH Zurich May 2014.

_ Xing Cui, Lanyu Shang, and Jing Zhang, "What Matters: Agreement Between U.S. Courts of Appeals Judges," Technical Report 2016.

Chen, Daniel, Yosh Halberstam, and Alan C. L. Yu, "Perceived masculinity predicts court outcomes at the United States Supreme Court," Working Paper, ETH Zurich, Mimeo 2014.

_ , and Alan Yu, "Covering: Mutable Characteristics and Perceptions of (Masculine) Voice in the U.S. Supreme Court," Technical Report, Department of Economics-Toulouse School of Economics 2016.

Chew, Pat K. and Robert E. Kelley, "Myth of the Color-Blind Judge: An Empirical Analysis of Racial Harassment Cases," Washington University Law Review, 2009, 86, 1117-1166.

Chilton, Adam S and Marin K Levy, "Challenging the Randomness of Panel Assignment in the Federal Courts of Appeals," Cornell L. Rev., 2015, 101, 1.

Clark, Tom S., Jeffrey K. Staton, Eugene Agchtein, and Yu Wang, "Revealed Public Opinion on Twitter: The Supreme Court of the United States Same-Sex Marriage Decisions," Working Paper, Emory University March 2014.

Cohen, Geoffrey L., "Party Over Policy: The Dominating Impact of Group Influence on Political Beliefs," Journal of Personality and Social Psychology, 2003, 85 (5), 808-822.

Collins, Willaim J. and Katharine L. Shester, "Slum Clearance and Urban Renewal in the United States," American Economic Journal: Applied Economics, January 2011, 5 (1), 239-273.

Deaton, Angus, "Instruments, Randomization, and Learning about Development," Journal of Economic Literature, September 2010, 48 (2), 424-455.

Dell, Melissa, "The Persistent Effects of Peru's Mining "Mita"," Econometrica, 2010, 78 (6), 1863-1903.

, Benjamin F. Jones, and Benjamin A. Olken, "Climate Change and Economic Growth: Evidence from the Last Half Century," American Economic Journal: Macroeconomics, 2012, 4 (3), 66-95.

DellaVigna, Stefano and Joshua M. Pollet, "Demographics and Industry Returns," The American Economic Review, 2007, 97 (5), 1667-1702.

Dinkelman, Taryn, "The Effects of Rural Electrification on Employment: New Evidence from South Africa," American Economic Review, September 2011, 101 (7), 3078-3108.

Dolbeare, Kenneth M. and Phillip E. Hammond, "The Political Party Basis of Attitudes Toward the Supreme Court," Public Opinion Quarterly, 1968, 32 (1), 16-30.

Donaldson, Dave, "Railroads of the Raj: Estimating the Impact of Transportation Infrastructure," American Economic Review, 2015, forthcoming.

Duflo, Esther and Rohini Pande, "Dams," The Quarterly Journal of Economics, 2007, 122 (2), 601-646.

Eagle, Steven J., "Does Blight Really Justify Condemnation?," Urban Lawyer, 2007, 39, 833-858.

Edwards, Harry T. and Michael A. Livermore, "Pitfalls of Empirical Studies That Attempt to Understand the Factors Affecting Appellate Decisionmaking," Duke Law Journal, 2008, 58 (8), 1895-1989.

Fennell, Lee Anne, "Taking Eminent Domain Apart," Michigan State Law Review, 2004, 957, 957-1004.

Field, Erica, "Property Rights and Investment in Urban Slums," Journal of the European Economic Association Papers and Proceedings, 2005, 3 (2-3), 279-290.

Fitzpatrick, Brian T, "An Empirical Study of Class Action Settlements and Their Fee Awards," Journal of Empirical Legal Studies, 2010, 7 (4), 811-846.

Frieden, Bernard J. and Lynne B. Sagalyn, Downtown, Inc: How America Rebuilds Cities, MIT Press, 1991.

Frost, Amanda and Stefanie Lindquist, "Countering the Majoritarian Difficulty," Virginia Law Review, 2010, 96 (4), 719-797.

Galasso, Alberto, Mark Schankerman et al., "Patents and Cumulative Innovation: Causal Evidence from the Courts," The Quarterly Journal of Economics, 2015, 130 (1), 317-369.

Garnett, Nicole Stelle, "The Neglected Political Economy of Eminent Domain," Michigan Law Review, October 2006, 105 (1), 101-150.

Gennaioli, Nicola and Andrei Shleifer, "The Evolution of Common Law," Journal of Political Economy, 
2007, 115, 43-68.

Glaeser, Edward L. and Andrei Shleifer, "The Rise of the Regulatory State," The Journal of Economic Literature, 2003, 41 (2), 401-425.

Goldman, Sheldon, Picking Federal Judges: Lower Court Selection from Roosevelt Through Reagan, Yale University Press, 1999.

Gonzalez-Navarro, Marco and Climent Quintana-Domeque, "Paving Streets for the Poor: Experimental Analysis of Infrastructure Effects," Review of Economics and Statistics, December 2014. (Revised and Resubmitted).

Hacker, Jacob S and Paul Pierson, American Amnesia: How the War on Government Led Us to Forget What Made America Prosper, Simon and Schuster, 2016.

Haire, Susan B., Donald R. Songer, and Stefanie A. Lindquist, "Appellate Court Supervision in the Federal Judiciary: A Hierarchical Perspective," Law \& Society Review, March 2003, 37 (1), $143-168$.

Hall, Matthew, "Randomness Reconsidered: Modeling Random Judicial Assignment in the U.S. Courts of Appeals," Journal of Empirical Legal Studies, 2010, 7 (3), 574-589.

Hamburger, Philip, Is Administrative Law Unlawful?, University of Chicago Press, 2014.

Hornbeck, Richard, "Barbed Wire: Property Rights and Agricultural Development," The Quarterly Journal of Economics, 2010, 125 (2), 767-810.

Innes, Robert, "Takings, Compensation, and Equal Treatment for Owners of Developed and Undeveloped Property," Journal of Law and Economics, October 1997, 40 (2), 403-432.

Jensen, Robert, "The Digital Provide: Information (Technology), Market Performance, and Welfare in the South Indian Fisheries Sector," The Quarterly Journal of Economics, 2007, 122 (3), 879-924.

Jordan, Samuel P., "Early Panel Announcement, Settlement, and Adjudication," Brigham Young University Law Review, June 2007, 2007 (1), 55-107.

Kanner, Gideon, "Do We Need to Impair or Strengthen Property Rights in Order to "Fulfill Their Unique Role"? A Response to Professor Dyal-Chand," University of Hawai'i Law Review, 2009, 31 (2), 429 - 433.

Kaplow, Louis, "An Economic Analysis of Legal Transitions," Harvard Law Review, 1986,99 (3), $509-617$.

Kastellec, Jonathan P., "Racial Diversity and Judicial Influence on Appellate Courts," American Journal of Political Science, January 2013, 57 (1), 167-183.

Katz, Daniel Martin, Michael James Bommarito, Tyler Soellinger, and James Ming Chen, "Law on the Market? Evaluating the Securities Market Impact of Supreme Court Decisions," SSRN (August 24, 2015), 2015.

Keele, Denise M., Robert W. Malmsheimer, Donald W. Floyd, and Lianjun Zhang, "An Analysis of Ideological Effects in Published Versus Unpublished Judicial Opinions," Journal of Empirical Legal Studies, 2009, 6 (1), 213-239.

Klarman, Michael, From Jim Crow to Civil Rights: The Supreme Court and the Struggle for Racial Equality, New York: Oxford University Press, 2004.

Klarman, Michael J., "Brown and Lawrence (and Goodridge)," Michigan Law Review, December 2005, 104 (3), 431-489.

Kline, Patrick and Enrico Moretti, "Local Economic Development, Agglomeration Economies, and the Big Push: 100 Years of Evidence from the Tennessee Valley Authority," The Quarterly Journal of Economics, February 2014, 129 (1), 275-331.

La Porta, Rafael, Florencio Lopez-de-Silanes, and Andrei Shleifer, "The Economic Consequences of Legal Origins," Journal of Economic Literature, May 2008, 46 (2), 285-332.

December 1998, 106 (6), 1113-1155.

Lamoreaux, Naomi R., "The Mystery of Property Rights: A U.S. Perspective," The Journal of Economic History, 2011, 71 (2), 275-306.

LeGates, Richard T. and Chester Hartman, "Gentrification-Caused Displacement," The Urban Lawyer, $1982,14(1), 31-55$.

Libecap, Dean Lueck Gary D., "The Demarcation of Land and the Role of Coordinating Property Institutions," Journal of Political Economy, 2011, 119 (3), 426-467.

Maestas, Nicole, Kathleen J. Mullen, and Alexander Strand, "Does Disability Insurance Receipt Discourage Work? Using Examiner Assignment to Estimate Causal Effects of SSDI Receipt," American Economic Review, September 2013, 103 (5), 1797-1829.

Manski, Charles F., "Measuring Expectations," Econometrica, 2004, 72 (5), 1329-1376.

Mayshar, Joram, Omer Moav, and Zvika Neeman, "Transparency, Appropriability and the Early State," CEPR Discussion Papers 8548, London Centre for Economic Policy Research August 2011. 
Merritt, Deborah Jones and James J. Brudney, "Stalking Secret Law: What Predicts Publication in the United States Courts of Appeals," Vanderbilt Law Review, 2001, 54, 69-121.

Miceli, Thomas J. and Kathleen Segerson, "Regulatory Takings: When Should Compensation Be Paid?," The Journal of Legal Studies, 1994, 23 (2), 749-776.

Mnookin, Robert H. and Lewis Kornhauser, "Bargaining in the Shadow of the Law: The Case of Divorce," The Yale Law Journal, 1979, 88 (5), 950-997.

Morten, Melanie and Jaqueline Oliveira, "The long-run effects of roads: Evidence from planned capital cities," Technical Report, Stanford University, Department of Ecnomics 2013.

Munch, Patricia, "An Economic Analysis of Eminent Domain," The Journal of Political Economy, 1976, 84 (3), 473-498.

Nadler, Janice and Shari S. Diamond, "Eminent Domain and the Psychology of Property Rights: Proposed Use, Subjective Attachment, and Taker Identity," Journal of Empirical Legal Studies, 2008, 5 (4), 713-749.

_ Shari Seidman Diamond, and Matthew M. Patton, "Government Takings of Private Property: Kelo and the Perfect Storm," in Nathaniel Persily, Jack Citrin, and Patrick J. Egan, eds., Public Opinion and Constitutional Controversy, Oxford University Press, 2008, chapter 12, pp. 287-310.

Nakamura, Emi and Jon Steinsson, "Fiscal Stimulus in a Monetary Union: Evidence from U.S. Regions," Working Paper 17391, National Bureau of Economic Research September 2011.

Nash, Jonathan R., "Examining Federal District Judges' Referrals to Magistrate Judges," in "2015 Annual Meeting of the International Society of New Institutional Economics (ISNIE)" number 1-44 June 2015.

Nielsen, Laiura B., Robert L. Nelson, and Ryon Lancaster, "Individual Justice or Collective Legal Mobilization? Employment Discrimination Litigation in the Post Civil Rights United States," Journal of Empirical Legal Studies, 2010, 7 (2), 175-201.

North, Douglas C. and Robert P. Thomas, The Rise of the Western World: A New Economic History, Cambridge University Press, 1973.

North, Douglass C. and Barry R. Weingast, "Constitutions and Commitment: The Evolution of Institutional Governing Public Choice in Seventeenth-Century England," The Journal of Economic History, 1989, 49 (4), 803-832.

Pastor, Kate, "3251 Broadway," Working Paper, Urban Affairs 2007.

Pollak, Daniel, Have the U.S. Supreme Court's 5th Amendment Takings Decisions Changed Land Use Planning in California?, Diane Publishing Company, 2001.

Posner, Richard A., "Against Constitutional Theory," New York University Law Review, April 1998, 73 (1), 1-22.

Radin, Margaret Jane, "Property and Personhood," Stanford Law Review, 1982, 34 (5), 957-1015.

Reinhart, Eric, "Cities Within Cities," 2015. The Salon, Volume 7.

Rosenberg, Gerald N., The Hollow Hope: Can Courts Bring About Social Change? American Politics and Political Economy, University of Chicago Press, 1993.

Roth, Randall W., The Price of Paradise - Lucky We Live in Hawaii?, Mutual Publishing, 1992.

Sandefur, Timothy, "A Gleeful Obituary for Poletown Neighborhood Council v. Detroit," Harvard Journal of Law and Public Policy, 2005, 28, 651-678.

Scherer, Nancy, "Blacks on the Bench," Political Science Quarterly, 2004, 119 (4), 655-675.

Semuels, Alana, "The Role of Highways in American Poverty," 2016. The Atlantic, May 18, 2016.

Sen, Maya, "Is Justice Really Blind? Race and Appellate Review in U.S. Courts," Journal of Legal Studies, 2015, 44 (1). (In Press).

Shaw, Aaron D., John J. Horton, and Daniel L. Chen, "Designing Incentives for Inexpert Human Raters," in "Proceedings of the ACM 2011 conference on Computer supported cooperative work" New York 2011, pp. 275-284.

Sherwood, David H., "Residential Relocation through Expropriation: A Case Study Near Welland, Ontario," Master thesis, Wilfrid Laurier University 1975.

Shleifer, Andrei, "Efficient Regulation," in Daniel Kessler, ed., Regulation vs. Litigation, National Bureau of Economic Resarch and University of Chicago Press, 2010, pp. 27-44.

Slemrod, Joel and Shlomo Yitzhaki, "Tax Avoidance, Evasion, and Administration," in A. J. Auerbach and M. Feldstein, eds., Handbook of Public Economics, 1 ed., Vol. 3, Elsevier, 2002, chapter 22, pp. 14231470.

Somin, Ilya, "Overcoming Poletown: County of Wayne v. Hathcock, Economic Development Takings, and the Future of Public Use," Michigan State Law Review, 2004, 4, 1005-1039.

Soto, Hernando De, The Mystery of Capital: Why Capitalism Triumphs in the West and Fails Everywhere 
Else Basic books, Basic Books, 2000.

Steinbuch, Robert, "An Empirical Analysis of Reversal Rates in the Eighth Circuit During 2008," Loyola of Los Angeles Law Review, 2009, 43, 51-19.

Stevenson, Betsey and Justin Wolfers, "Bargaining in the Shadow of the Law: Divorce Laws and Family Distress," The Quarterly Journal of Economics, 2006, 121 (1), 267-288.

Sunstein, Cass R., "On the Expressive Function of Law," University of Pennsylvania Law Review, May 1996, 144 (5), 2021-2053.

, David Schkade, Lisa M. Ellman, and Andres Sawicki, Are Judges Political?: An Empirical Analysis of the Federal Judiciary, Brookings Institution Press, 2006.

Taha, Ahmed E., "Publish or Paris? Evidence of How Judges Allocate Their Time," American Law and Economics Review, 2004, 6 (1), 1-27.

, "Judge Shopping: Testing Whether Judges' Political Orientations Affect Case Filings," University of Cincinnati Law Review, 2009, 20, 101-135.

U.S. Department of Transportation, Federal Highway Administration, "Acquiring Real Property for Federal and Federal-aid Programs and Projects," June 2005. Publication No. FHWA-HEP-05-030.

Waldfogel, Joel, "The Selection Hypothesis and the Relationship between Trial and Plaintiff Victory," The Journal of Political Economy, 1995, 103, 229-260. 


\begin{tabular}{|c|c|}
\hline Circuit-Year Level & $\begin{array}{c}\text { Mean } \\
\text { [Standard } \\
\text { Deviation] }\end{array}$ \\
\hline Panel A: Physical Takings Cases (1975-2008) & $\begin{array}{l}17.66 \\
{[7.72]}\end{array}$ \\
\hline Number of Physical Takings Panels & $\begin{array}{l}0.33 \\
{[0.63]}\end{array}$ \\
\hline Proportion of Circuit-Years with Physical Takings Panels & $27 \%$ \\
\hline Proportion of Pro-Government Physical Takings Decisions when Circuit-Year has Panels & $66 \%$ \\
\hline $\begin{array}{l}\text { Expected \# of Racial Minority Democratic Appointees per Seat when the } \\
\text { Circuit-Year has Panels }\end{array}$ & $\begin{array}{c}0.06 \\
{[0.06]}\end{array}$ \\
\hline Expected \# Republican Prior U.S. Attorneys per Seat when Circuit-Year has Panels & $\begin{array}{c}0.04 \\
{[0.06]}\end{array}$ \\
\hline Number of Physical Takings District Cases & $\begin{array}{l}1.54 \\
{[1.96]}\end{array}$ \\
\hline $\mathrm{N}$ (circuit-years) & 402 \\
\hline $\begin{array}{l}\text { Panel B: Regulatory Takings Cases (1979-2004) } \\
\text { Number of Judges }\end{array}$ & $\begin{array}{l}17.81 \\
{[7.46]}\end{array}$ \\
\hline Number of Regulatory Takings Panels & $\begin{array}{c}0.71 \\
{[0.99]}\end{array}$ \\
\hline Proportion of Circuit-Years with Regulatory Takings Panels & $46 \%$ \\
\hline Proportion of Pro-Government Regulatory Takings Decisions when Circuit-Year has Panels & $78 \%$ \\
\hline $\begin{array}{l}\text { Expected \# of Judges with ABA scores of well-qualified or better per Seat } \\
\text { when Circuit-Year has Panels }\end{array}$ & $\begin{array}{c}0.64 \\
{[0.13]}\end{array}$ \\
\hline Number of Regulatory Takings District Cases & $\begin{array}{l}1.58 \\
{[1.55]}\end{array}$ \\
\hline $\mathrm{N}$ (circuit-years) & 310 \\
\hline
\end{tabular}




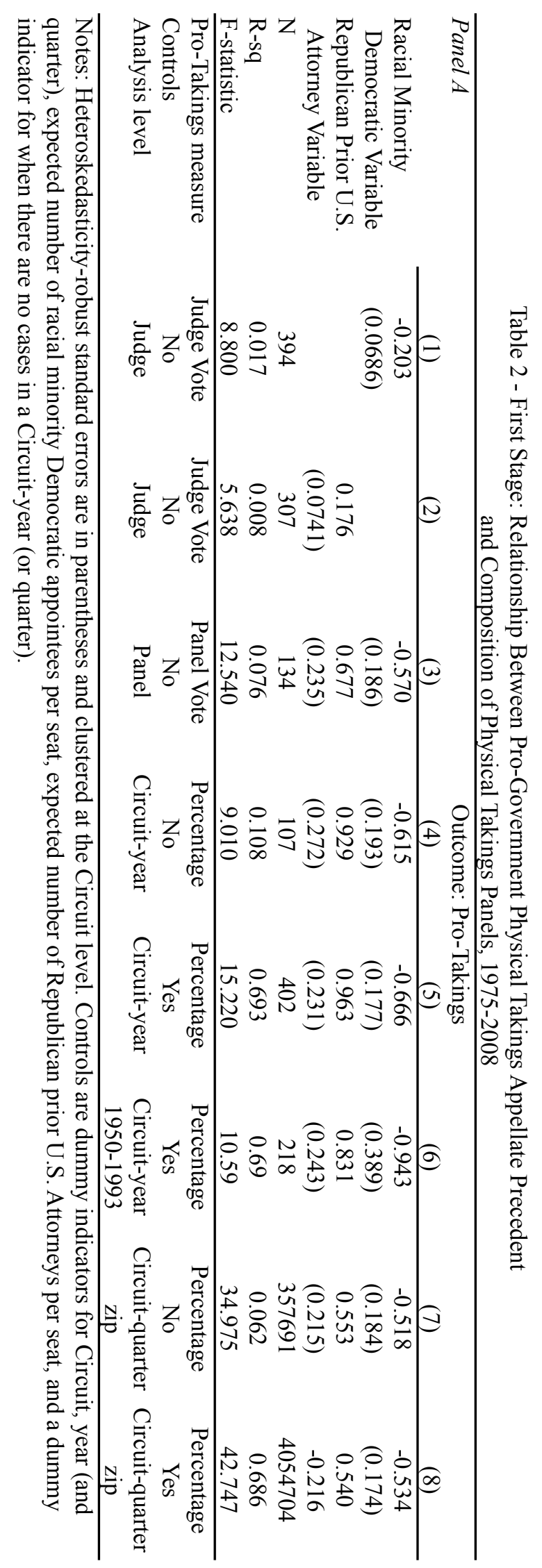




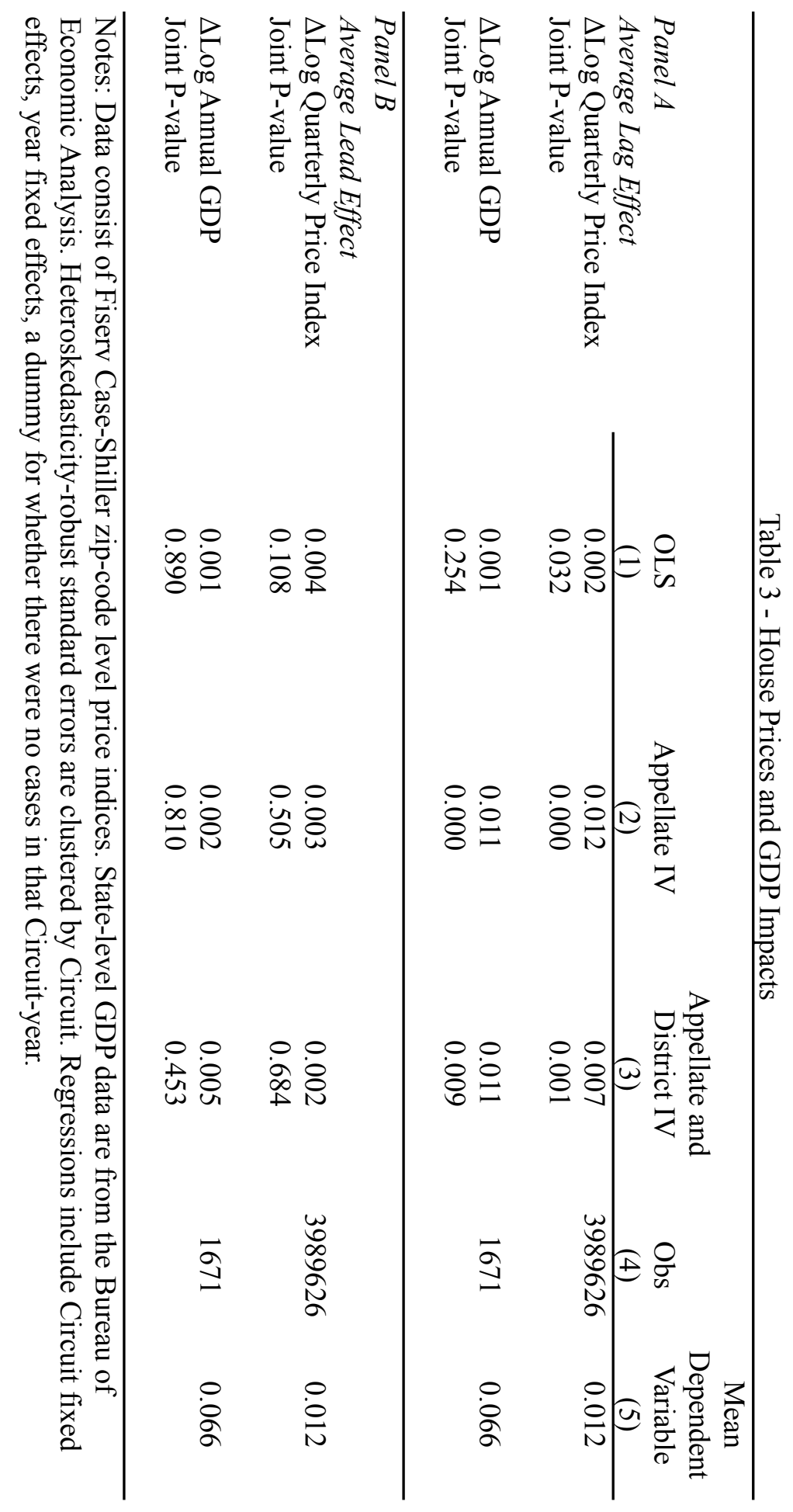


The Effect of Appellate Physical Takings Precedent on $\Delta$ Log Price Index Average of yearly lags

P-value of lags

(2)

(1)

A. Add Circuit-Specific Trends

B. No Fixed Effects

C. State Cluster

D. Control for Expectation

E. Use Population Weights

F. Drop 1 Circuit

Circuit 1

Circuit 2

Circuit 3

Circuit 4

Circuit 5

Circuit 6

Circuit 7

Circuit 8

Circuit 9

Circuit 10

Circuit 11

Circuit 12

0.012

0.006

0.012

0.017

0.015

0.012

0.010

0.013

0.012

0.013

0.011

0.014

0.012

0.010

0.012

0.013

0.012

0.000

0.002

0.000

0.000

0.000

0.000

0.000

0.000

0.000

0.000

0.000

0.000

0.000

0.000

0.000

0.000

0.000
P-value of leads

(3)

0.643

0.209

0.408

0.350

0.521

0.693

0.456

0.491

0.578

0.300

0.571

0.568

0.342

0.217

0.347

0.326

0.510

Notes: Significant at $+10 \%, * 5 \%, * * 1 \%$. Data consist of Fiserv Case-Shiller/FHFA zip-code level price indices.

Heteroskedasticity-robust standard errors are in parentheses and clustered by Circuit. Regressions include Circuit fixed effects, year and quarter fixed effects, and a dummy for whether there were no cases in that Circuit-year. The baseline regression is an instrumental variables specification with one lead and four lags of appellate physical takings precedent, corresponding to column 2 in Table 2. Instruments for appellate physical takings are racial minority Democratics per seat and Republican prior U.S. Attorneys per seat assigned to physical takings cases in a Circuit-year. Expectation controls are the expected probability of being assigned a racial minority Democratic per seat and a Republican prior U.S. Attorney per seat in a Circuit-year. Population weights are based on the 2005 US Census estimates at the zip-code level. 
Table 5 - Dynamic Housing Price Response

\begin{tabular}{|c|c|c|c|c|c|c|}
\hline \multirow[b]{2}{*}{ Panel A: Yearly Lags } & \multicolumn{6}{|c|}{$\Delta \log$ Quarterly Price Index } \\
\hline & $(\mathrm{t} 0)$ & $(\mathrm{t} 1)$ & $(\mathrm{t} 2)$ & $(\mathrm{t} 3)$ & $(\mathrm{t} 4)$ & $(\mathrm{t} 5)$ \\
\hline \multirow{2}{*}{ 1. Add Circuit-Specific Trends } & 0.010 & 0.013 & 0.019 & 0.014 & 0.006 & \\
\hline & $(0.006)$ & $(0.004)$ & $(0.004)$ & $(0.005)$ & $(0.002)$ & \\
\hline \multirow[t]{2}{*}{ 2. No Fixed Effects } & -0.000 & -0.003 & 0.015 & 0.018 & 0.001 & \\
\hline & $(0.007)$ & $(0.004)$ & $(0.009)$ & $(0.010)$ & $(0.006)$ & \\
\hline \multirow[t]{2}{*}{ 3. State Cluster } & 0.010 & 0.014 & 0.019 & 0.012 & 0.006 & \\
\hline & $(0.005)$ & $(0.005)$ & $(0.005)$ & $(0.004)$ & $(0.003)$ & \\
\hline \multirow[t]{2}{*}{ 4. Control for Expectation } & 0.016 & 0.021 & 0.023 & 0.015 & 0.010 & \\
\hline & $(0.009)$ & $(0.006)$ & $(0.003)$ & $(0.004)$ & $(0.003)$ & \\
\hline \multirow[t]{2}{*}{ 5. Use Population Weights } & 0.014 & 0.019 & 0.023 & 0.014 & 0.005 & \\
\hline & $(0.007)$ & $(0.006)$ & $(0.005)$ & $(0.004)$ & $(0.002)$ & \\
\hline \multirow[t]{2}{*}{ 6. Drop Circuit 1} & 0.008 & 0.013 & 0.019 & 0.012 & 0.005 & \\
\hline & $(0.006)$ & $(0.004)$ & $(0.003)$ & $(0.004)$ & $(0.002)$ & \\
\hline \multirow[t]{2}{*}{ Drop Circuit 2} & 0.006 & 0.011 & 0.017 & 0.009 & 0.006 & \\
\hline & $(0.006)$ & $(0.005)$ & $(0.005)$ & $(0.004)$ & $(0.001)$ & \\
\hline \multirow[t]{2}{*}{ Drop Circuit 3} & 0.012 & 0.016 & 0.019 & 0.012 & 0.006 & \\
\hline & $(0.006)$ & $(0.003)$ & $(0.003)$ & $(0.004)$ & $(0.002)$ & \\
\hline \multirow[t]{2}{*}{ Drop Circuit 4} & 0.010 & 0.014 & 0.019 & 0.012 & 0.006 & \\
\hline & $(0.006)$ & $(0.004)$ & $(0.003)$ & $(0.004)$ & $(0.001)$ & \\
\hline \multirow[t]{2}{*}{ Drop Circuit 5} & 0.012 & 0.013 & 0.019 & 0.015 & 0.004 & \\
\hline & $(0.006)$ & $(0.004)$ & $(0.004)$ & $(0.004)$ & $(0.002)$ & \\
\hline \multirow[t]{2}{*}{ Drop Circuit 6} & 0.008 & 0.011 & 0.018 & 0.013 & 0.007 & \\
\hline & $(0.006)$ & $(0.004)$ & $(0.002)$ & $(0.003)$ & $(0.002)$ & \\
\hline \multirow[t]{2}{*}{ Drop Circuit 7} & 0.010 & 0.014 & 0.023 & 0.015 & 0.007 & \\
\hline & $(0.006)$ & $(0.004)$ & $(0.003)$ & $(0.004)$ & $(0.002)$ & \\
\hline \multirow[t]{2}{*}{ Drop Circuit 8} & 0.010 & 0.013 & 0.018 & 0.013 & 0.005 & \\
\hline & $(0.006)$ & $(0.005)$ & $(0.004)$ & $(0.004)$ & $(0.002)$ & \\
\hline \multirow[t]{2}{*}{ Drop Circuit 9} & 0.007 & 0.011 & 0.018 & 0.011 & 0.005 & \\
\hline & $(0.006)$ & $(0.010)$ & $(0.009)$ & $(0.009)$ & $(0.009)$ & \\
\hline \multirow[t]{2}{*}{ Drop Circuit 10} & 0.011 & 0.015 & 0.019 & 0.012 & 0.006 & \\
\hline & $(0.005)$ & $(0.004)$ & $(0.003)$ & $(0.004)$ & $(0.002)$ & \\
\hline \multirow[t]{2}{*}{ Drop Circuit 11} & 0.012 & 0.016 & 0.020 & 0.013 & 0.005 & \\
\hline & $(0.007)$ & $(0.004)$ & $(0.004)$ & $(0.005)$ & $(0.003)$ & \\
\hline \multirow[t]{2}{*}{ Drop Circuit 12} & 0.010 & 0.014 & 0.019 & 0.012 & 0.006 & \\
\hline & $(0.006)$ & $(0.004)$ & $(0.003)$ & $(0.004)$ & $(0.002)$ & \\
\hline 7. $1 \mathrm{Lag}$ & 0.004 & 0.004 & & & & \\
\hline & $(0.003)$ & $(0.003)$ & & & & \\
\hline 2 Lags & 0.004 & 0.010 & 0.016 & & & \\
\hline & $(0.003)$ & $(0.004)$ & $(0.003)$ & & & \\
\hline 2 Leads, 4 Lags & 0.010 & 0.016 & 0.018 & 0.010 & 0.004 & \\
\hline & $(0.006)$ & $(0.005)$ & $(0.003)$ & $(0.004)$ & $(0.002)$ & \\
\hline 1 Lead, 5 Lags & 0.011 & 0.012 & 0.017 & 0.014 & 0.003 & -0.005 \\
\hline & $(0.005)$ & $(0.004)$ & $(0.003)$ & $(0.004)$ & $(0.002)$ & $(0.003)$ \\
\hline Panel B: Yearly Leads & $(\mathrm{t} 1)$ & $(\mathrm{t} 0)$ & (f1) & $(\mathrm{f} 2)$ & (f3) & (f4) \\
\hline 4 Leads, 1 Lag & 0.005 & 0.004 & -0.004 & -0.005 & -0.004 & 0.001 \\
\hline & $(0.003)$ & $(0.003)$ & $(0.004)$ & $(0.004)$ & $(0.004)$ & $(0.004)$ \\
\hline$\overline{\text { Panel C: Quarterly Lags }}$ & $(\mathrm{q} 0)$ & $(q 4)$ & $(q 8)$ & (q12) & $(q 16)$ & Mean \\
\hline 1. Circuit-quarter laws & 0.009 & 0.003 & 0.017 & 0.008 & 0.003 & 0.010 \\
\hline & $(0.003)$ & $(0.007)$ & $(0.008)$ & $(0.007)$ & $(0.006)$ & \\
\hline 2. Circuit-quarter laws $\left(\operatorname{Law}_{\mathrm{ct}}\right)$ & 0.009 & -0.000 & 0.011 & 0.004 & -0.000 & 0.007 \\
\hline controlling for & $(0.004)$ & $(0.008)$ & $(0.005)$ & $(0.006)$ & $(0.005)$ & \\
\hline Local takings decision ( LocalLaw $_{\text {ict }}$ ) & -0.018 & 0.014 & -0.000 & -0.013 & 0.010 & 0.005 \\
\hline & $(0.025)$ & $(0.022)$ & $(0.029)$ & $(0.040)$ & $(0.023)$ & \\
\hline
\end{tabular}




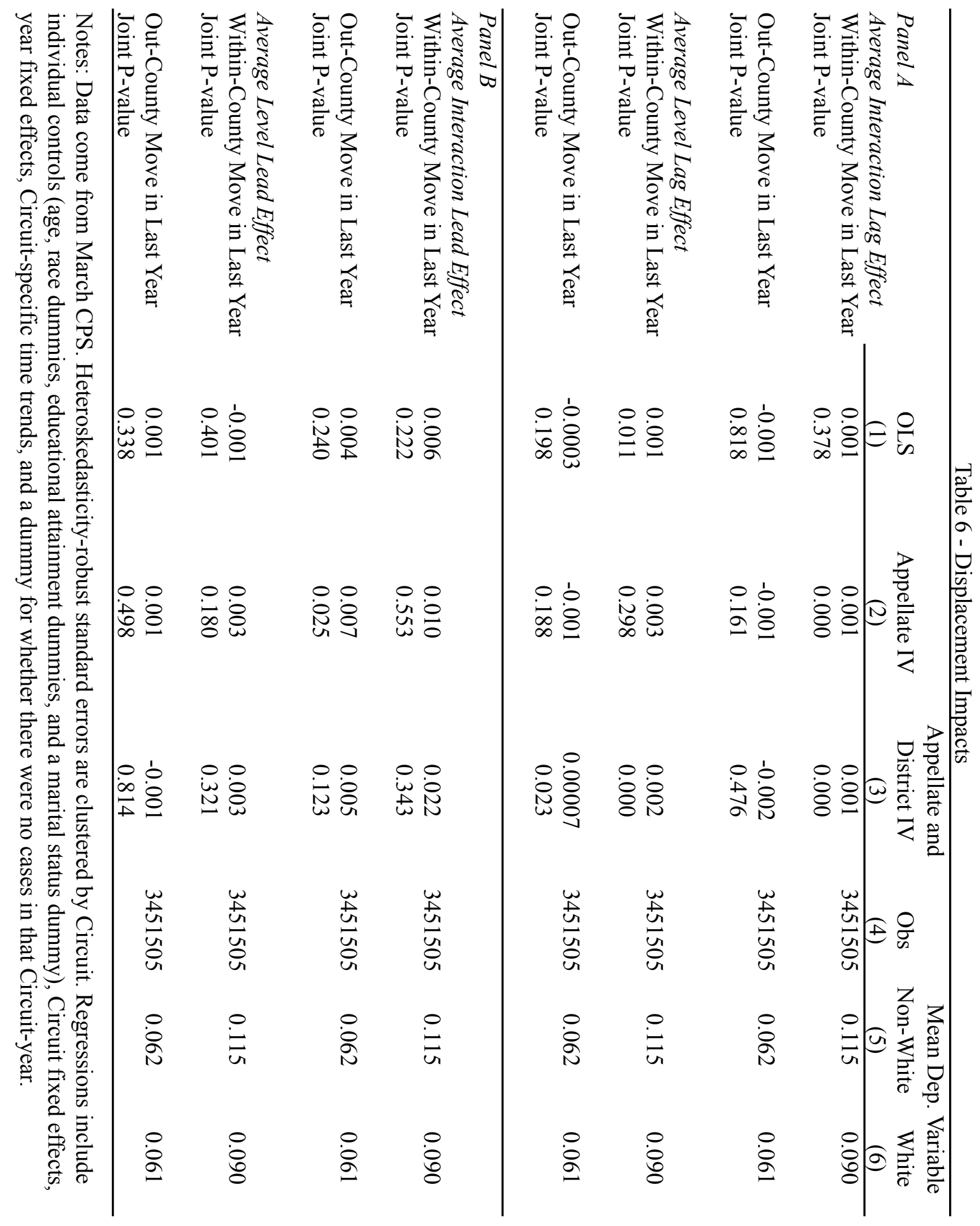




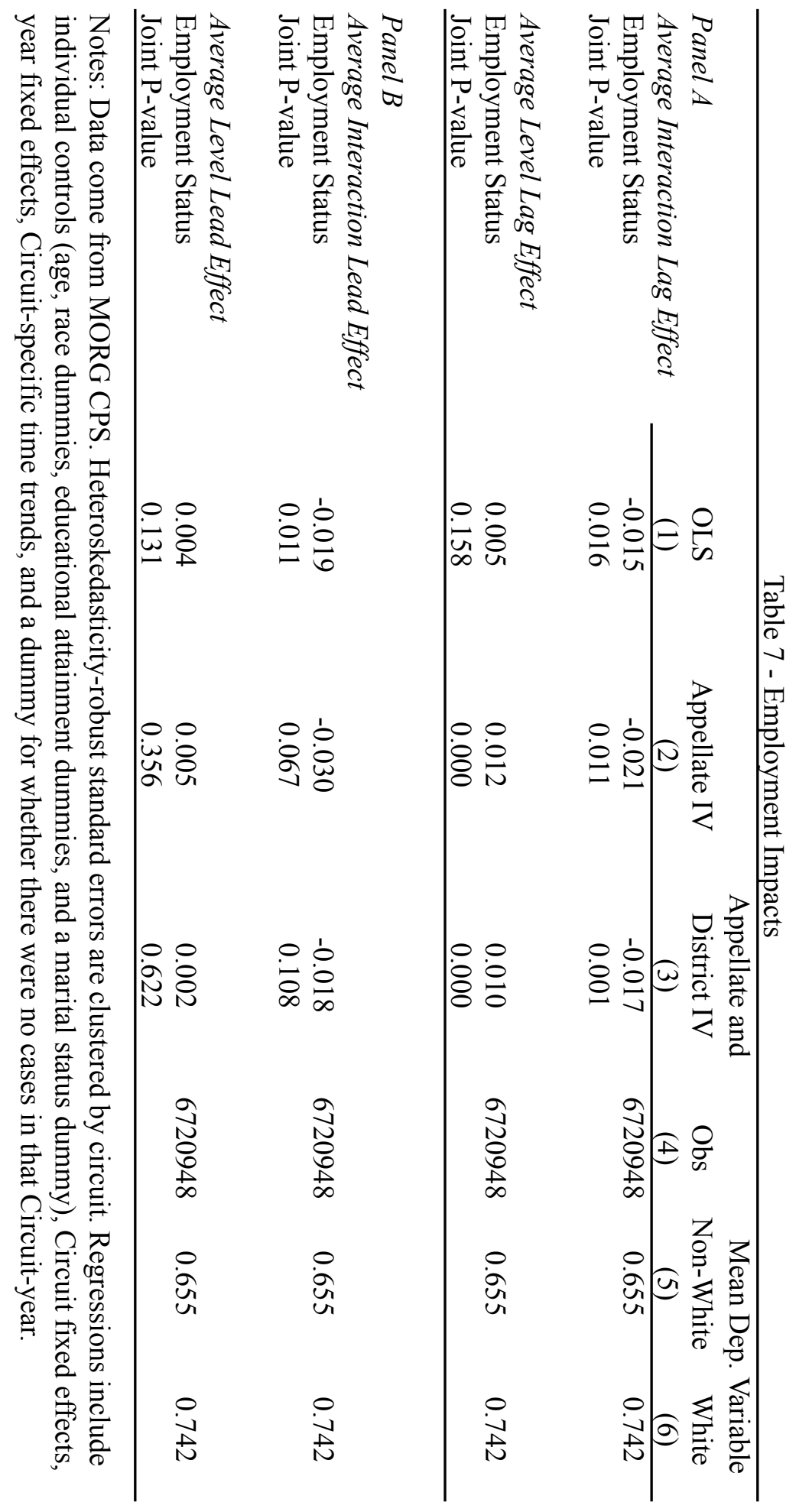




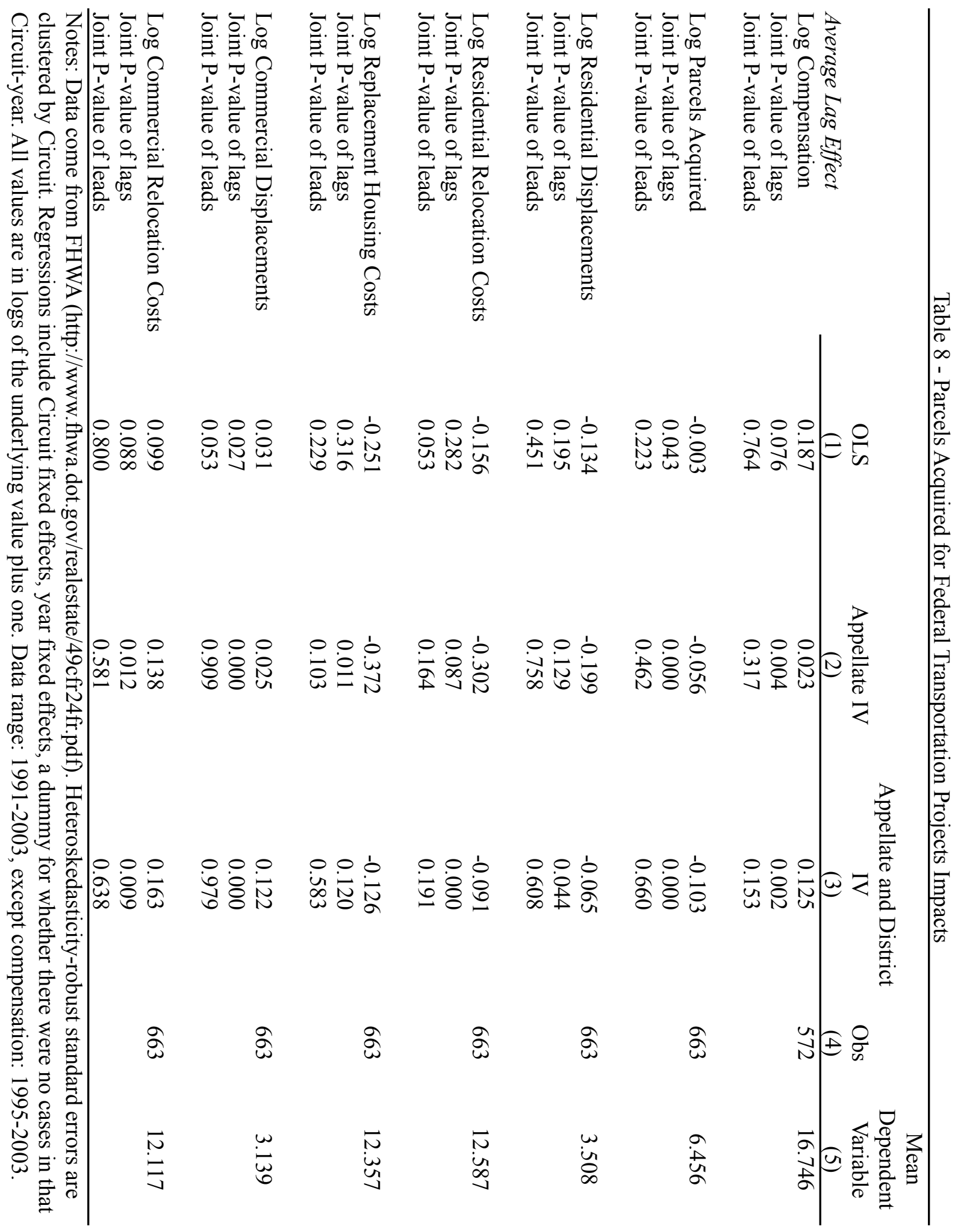




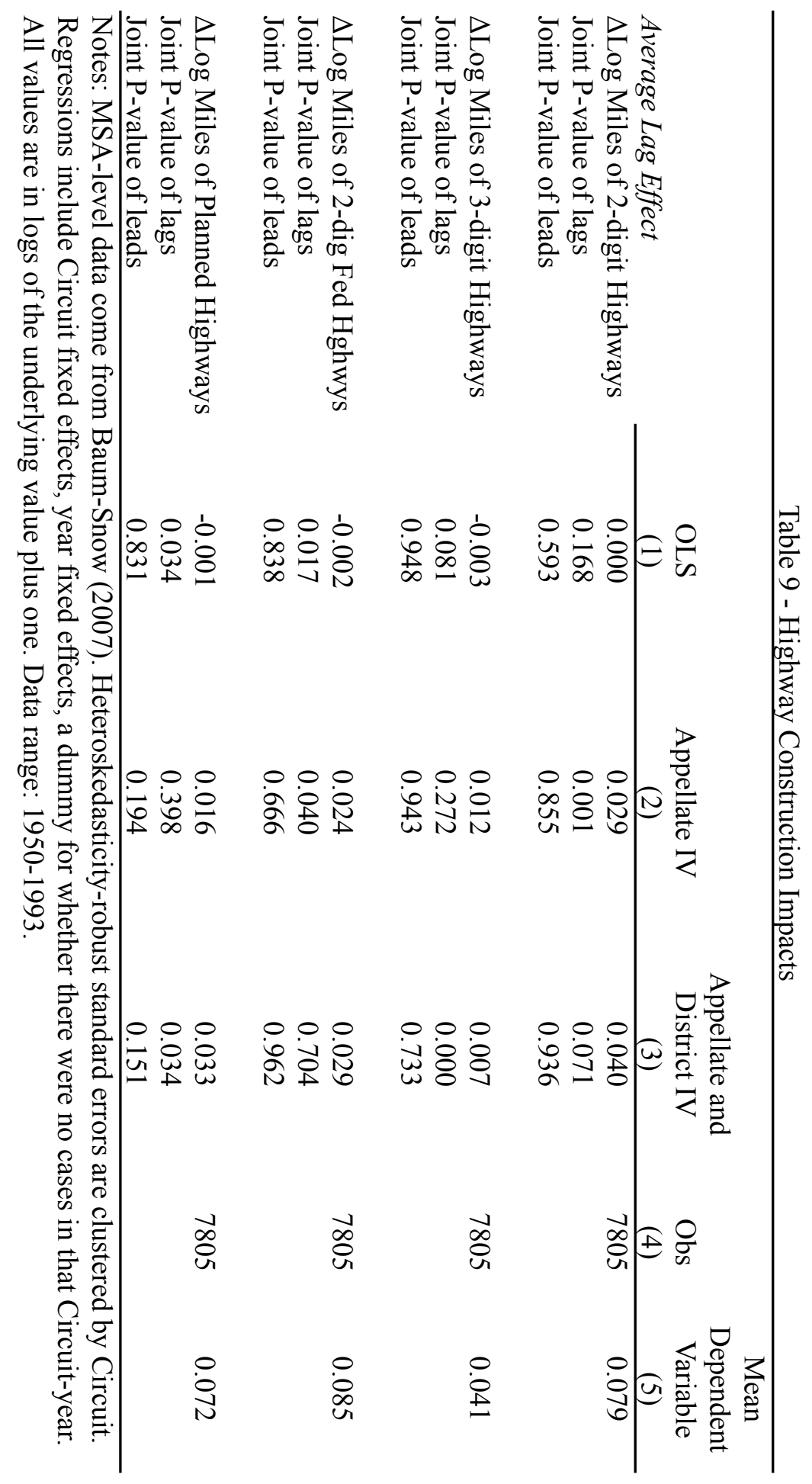




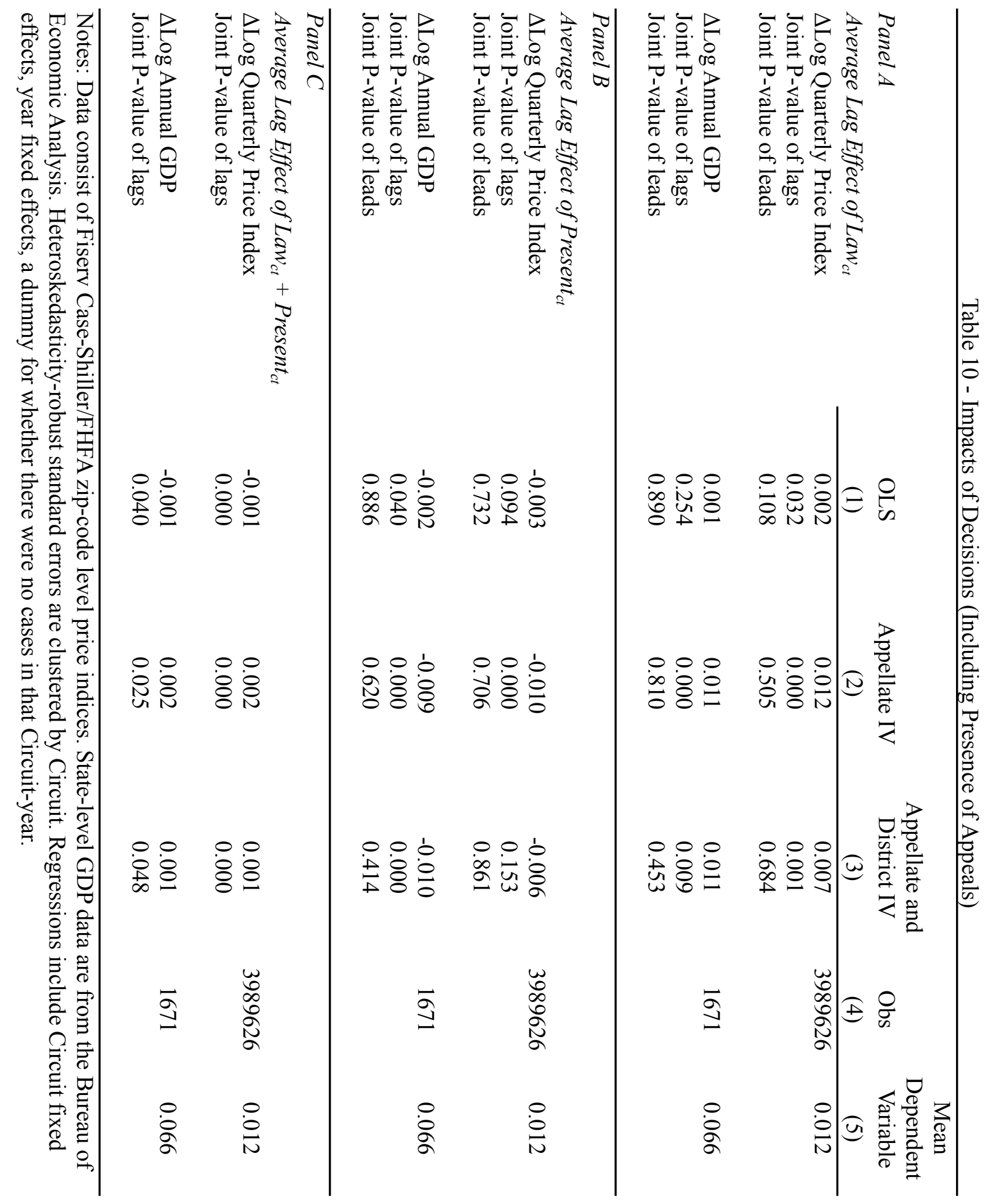


Table 11 - Impacts of Regulatory Takings Precedent

\begin{tabular}{|c|c|c|c|c|c|}
\hline \multicolumn{6}{|c|}{ Average Lag Effect } \\
\hline Panel A & OLS & LASSO IV & Obs & \multirow{2}{*}{\multicolumn{2}{|c|}{$\begin{array}{l}\text { Mean Dep. Variable } \\
\text { (4) }\end{array}$}} \\
\hline House Prices and GDP & $(1)$ & $(2)$ & (3) & & \\
\hline$\Delta$ Log Quarterly Price Index & 0.002 & 0.003 & 2486744 & \multicolumn{2}{|c|}{0.11} \\
\hline Joint P-value of lags & 0.086 & 0.000 & & & \\
\hline Joint P-value of leads & 0.005 & 0.333 & & & \\
\hline$\Delta$ Log Annual GDP & 0.005 & 0.002 & 1065 & & \\
\hline Joint P-value of lags & 0.024 & 0.017 & & & \\
\hline Joint P-value of leads & 0.897 & 0.918 & & & \\
\hline Panel B & \multicolumn{2}{|c|}{ Average Interaction Lag Effect } & Obs & Non-White & White \\
\hline \multicolumn{6}{|l|}{ Displacement } \\
\hline Within-County Move in Last Year & 0.002 & -0.002 & 2916474 & 0.118 & 0.091 \\
\hline Joint P-value of lags & 0.003 & 0.692 & & & \\
\hline Joint P-value of leads & 0.816 & 0.194 & & & \\
\hline Out-County Move in Last Year & -0.000 & 0.002 & 2916474 & 0.063 & 0.061 \\
\hline Joint P-value of lags & 0.031 & 0.000 & & & \\
\hline Joint P-value of leads & 0.523 & 0.316 & & & \\
\hline Employment Status & -0.011 & 0.004 & 5341620 & 0.660 & 0.750 \\
\hline Joint P-value of lags & 0.169 & 0.958 & & & \\
\hline Joint P-value of leads & 0.115 & 0.476 & & & \\
\hline Panel C & \multicolumn{2}{|c|}{ Average Lag Effect } & \multirow{4}{*}{663} & \\
\hline Log Residential Displacements & 0.202 & 1.127 & & \multicolumn{2}{|c|}{3.508} \\
\hline Joint P-value of lags & 0.383 & 0.496 & & & \\
\hline Joint P-value of leads & 0.594 & 0.719 & & & \\
\hline Log Commercial Displacements & 0.203 & -0.209 & \multirow[t]{3}{*}{663} & \multicolumn{2}{|c|}{3.139} \\
\hline Joint P-value of lags & 0.182 & 0.777 & & & \\
\hline Joint P-value of leads & 0.683 & 0.687 & & & \\
\hline$\Delta$ Log Miles of 2-digit Highways & 0.001 & 0.003 & \multirow[t]{3}{*}{2453} & \multicolumn{2}{|c|}{0.007} \\
\hline Joint P-value of lags & 0.529 & 0.636 & & & \\
\hline Joint P-value of leads & 0.113 & 0.401 & & & \\
\hline$\Delta$ Log Miles of Planned Highways & -0.000 & -0.001 & \multirow[t]{3}{*}{2453} & \multicolumn{2}{|c|}{0.002} \\
\hline Joint P-value of lags & 0.000 & 0.163 & & & \\
\hline Joint P-value of leads & 0.097 & 0.796 & & & \\
\hline Panel D & Fiserv & GDP & CPS & \multicolumn{2}{|c|}{ FHWA } \\
\hline \multicolumn{6}{|l|}{ First stage F-statistic } \\
\hline Appellate LASSO IV & 48.36 & 37.48 & 50.39 & \multicolumn{2}{|c|}{30.01} \\
\hline District LASSO IV & 6.53 & 6.43 & 11.51 & \multicolumn{2}{|c|}{9.24} \\
\hline
\end{tabular}




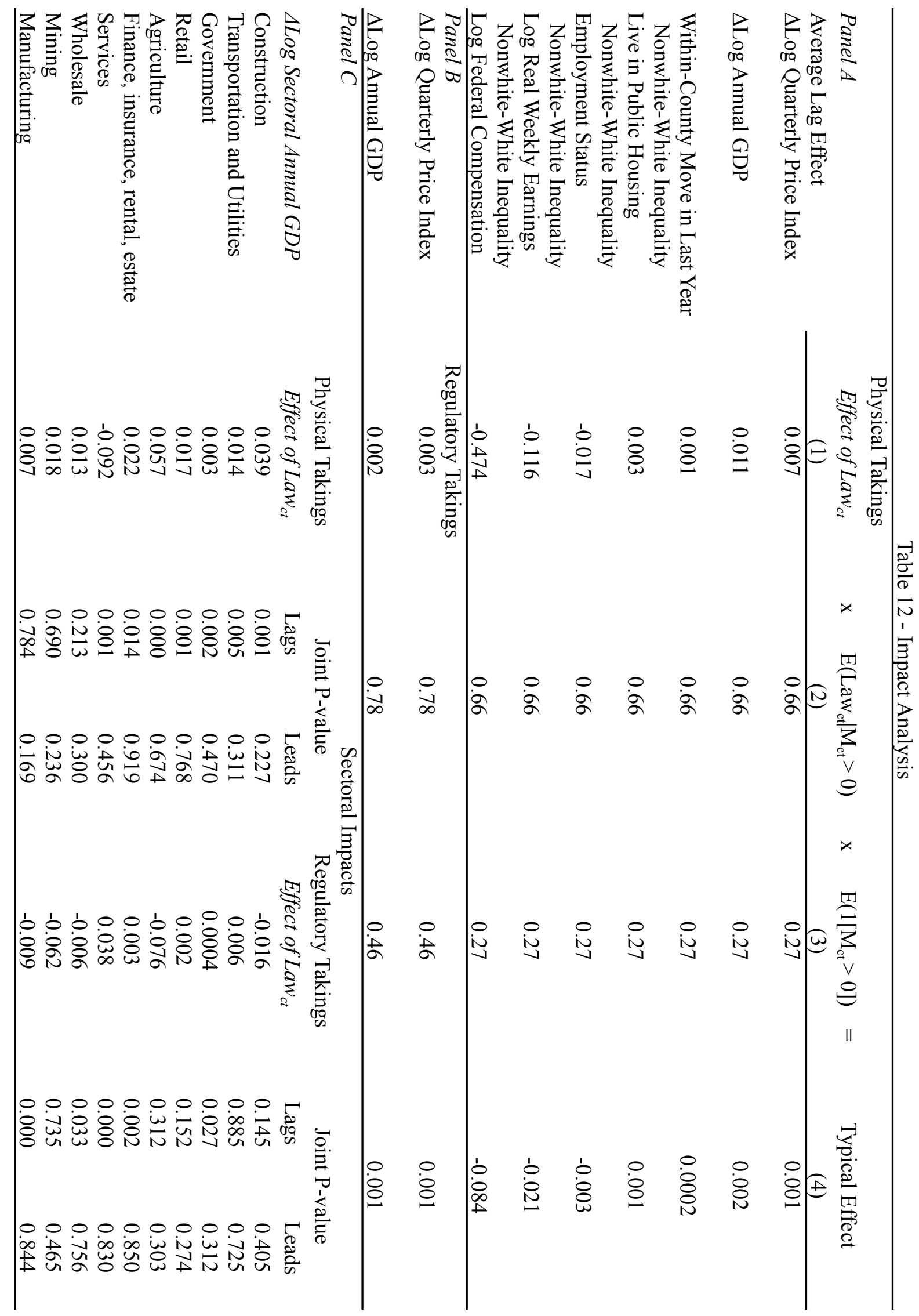


Figure 1

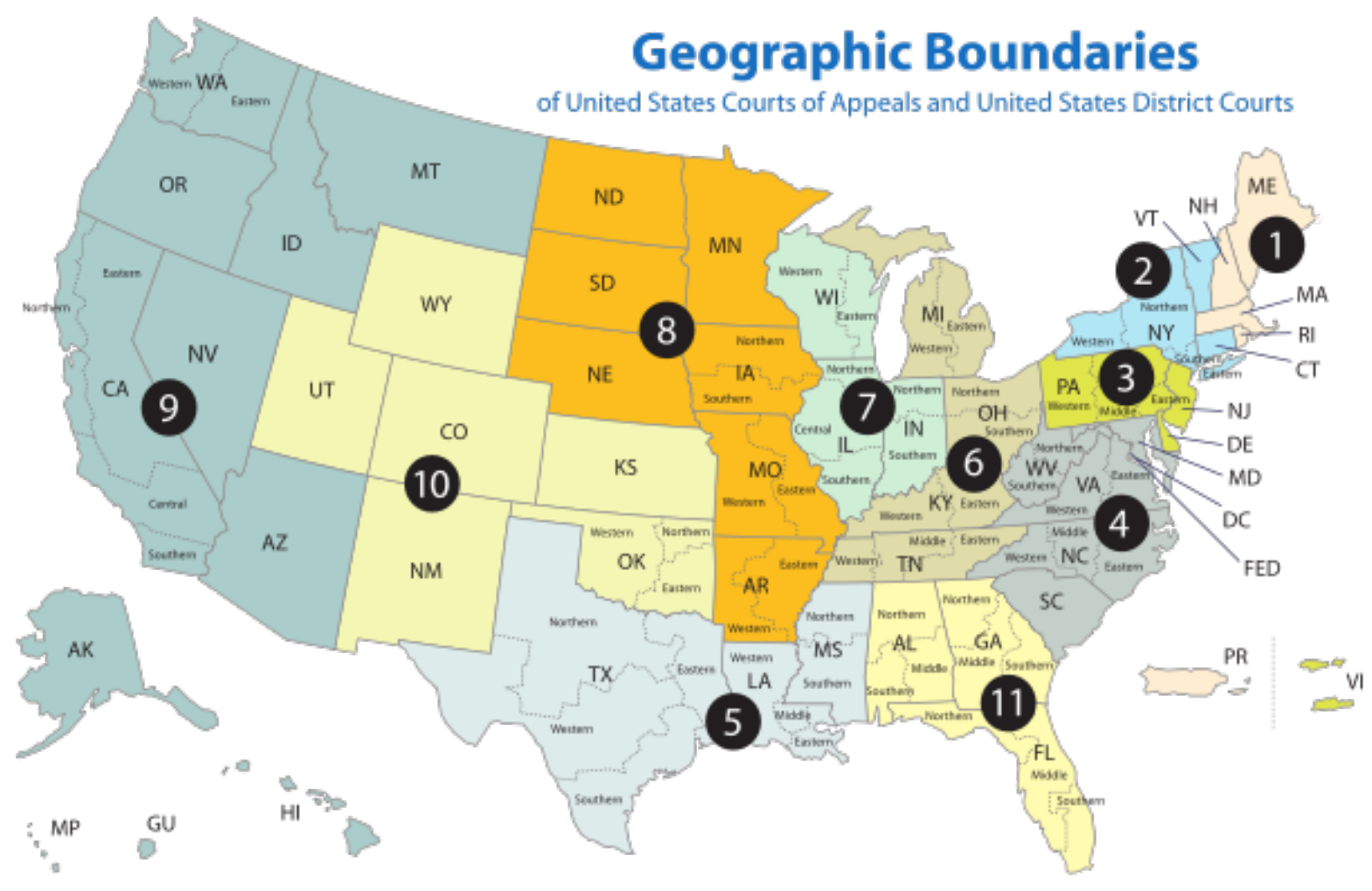

Figure 2 - Map of Alleged Takings

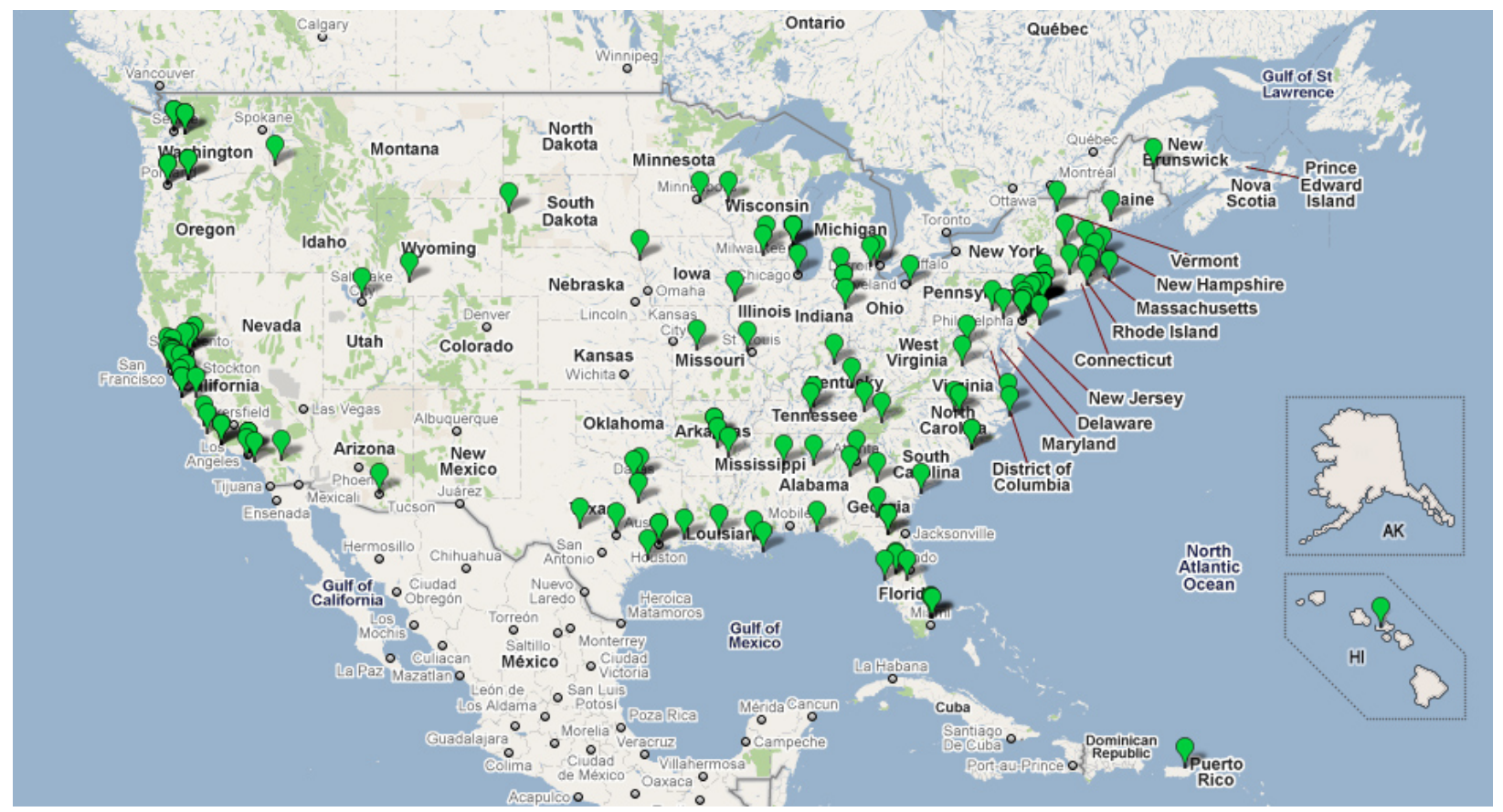


Figure 3 - Random Variation in Judicial Composition

\section{Random Variation by Circuit: Minority Democratic Appointees}
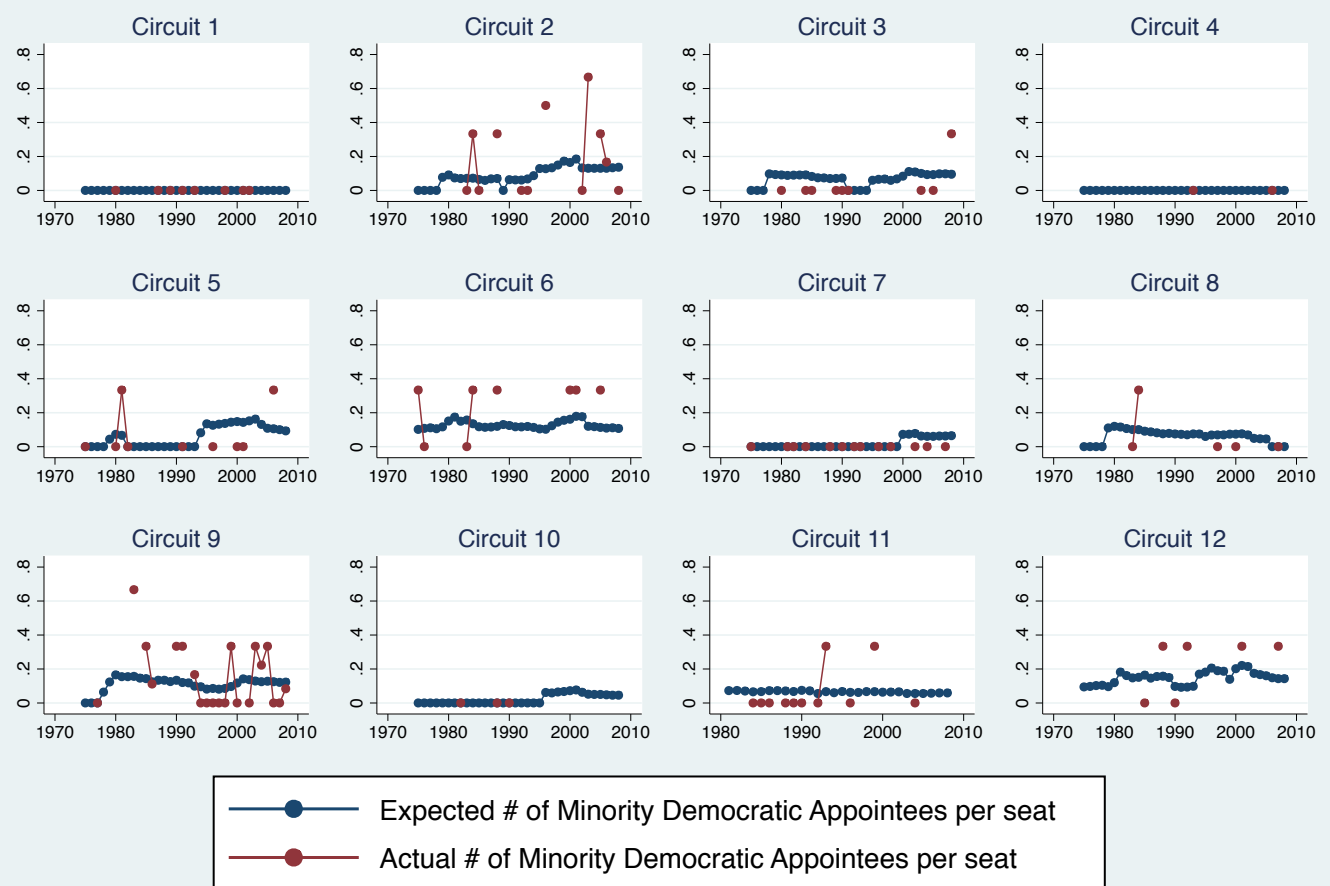

Random Variation by Circuit: Republican Prior U.S. Attorneys
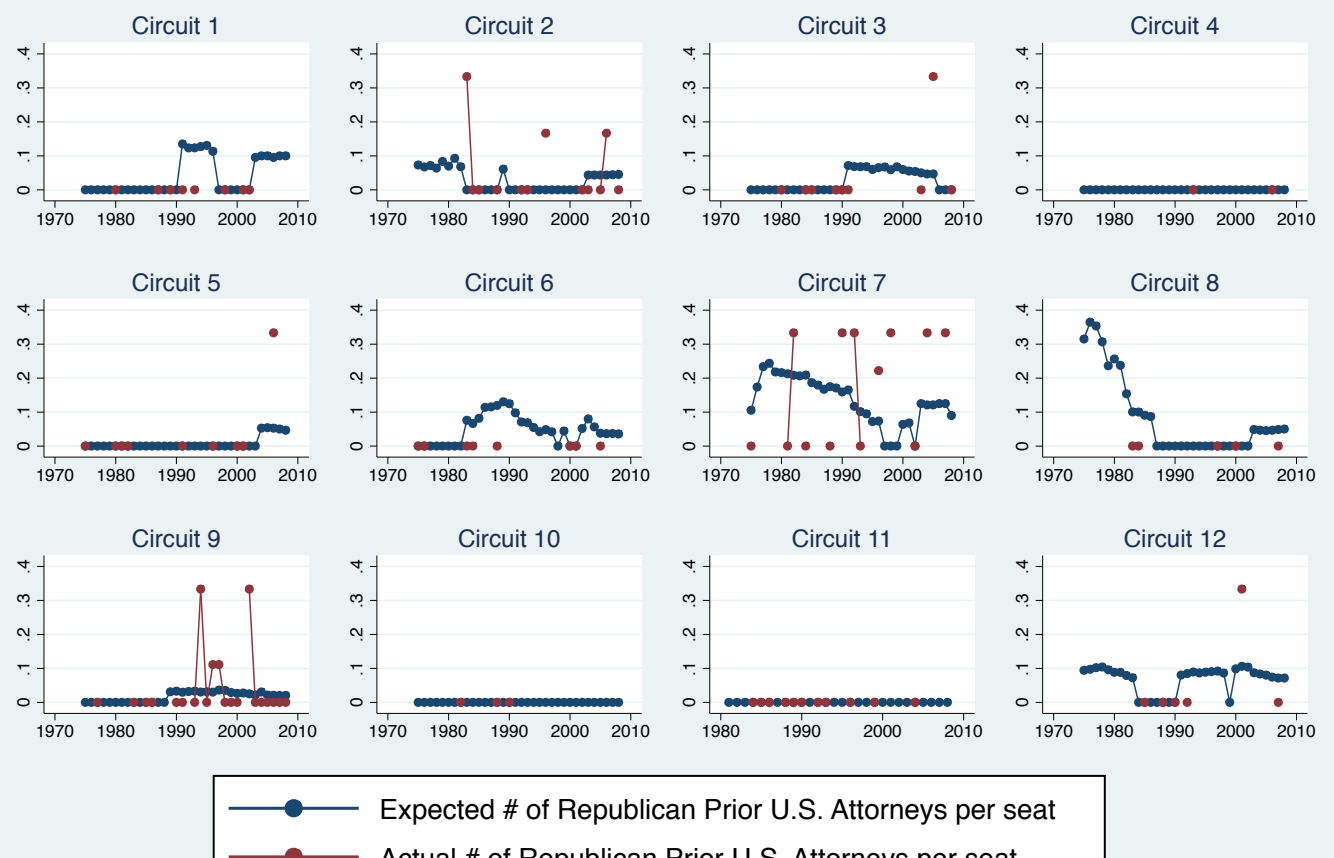
Actual \# of Republican Prior U.S. Attorneys per seat 
Figure 4 - Local Polynomial Estimates of First Stage

Pro-Government Physical Takings Decisions and Composition of Judicial Panels

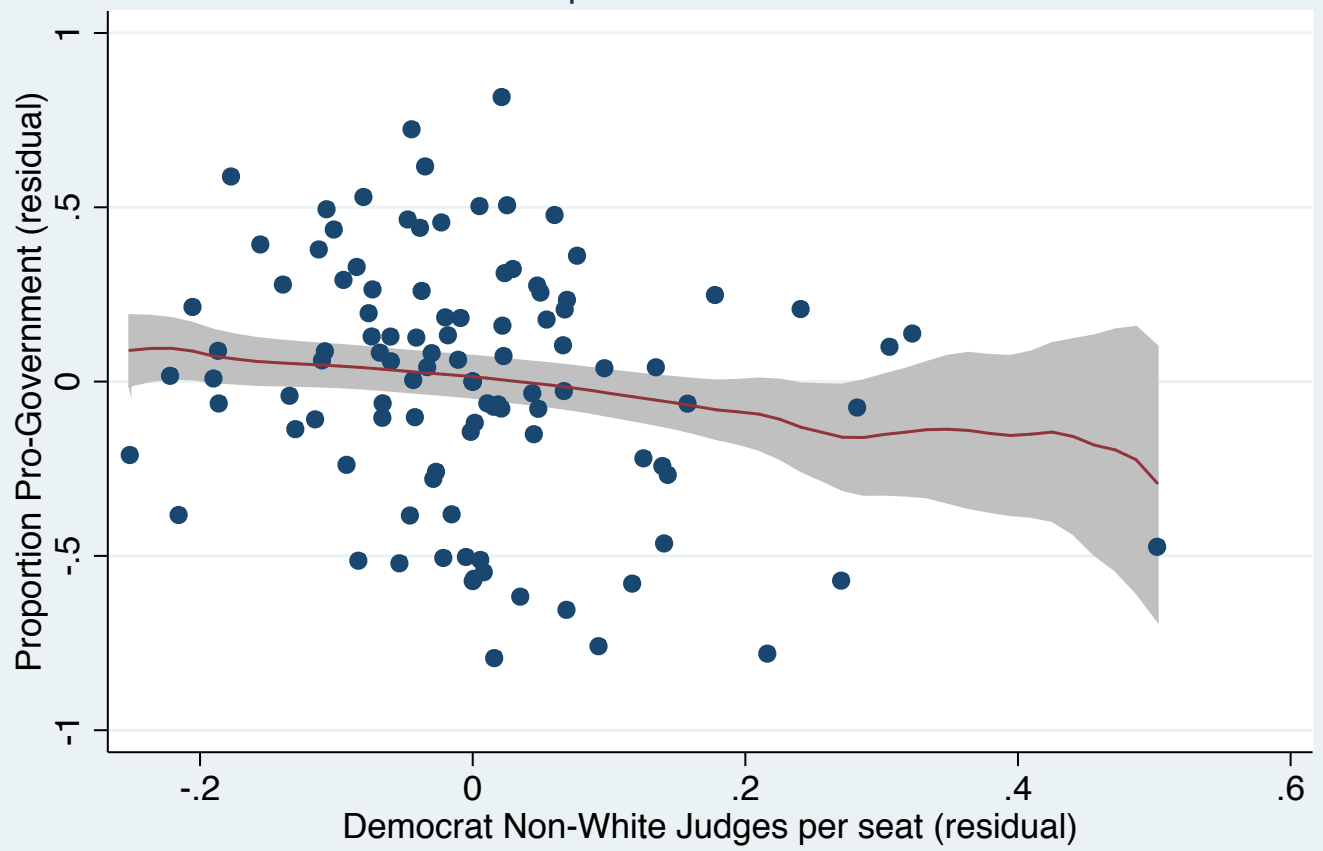

Pro-Government Physical Takings Decisions and Composition of Judicial Panels

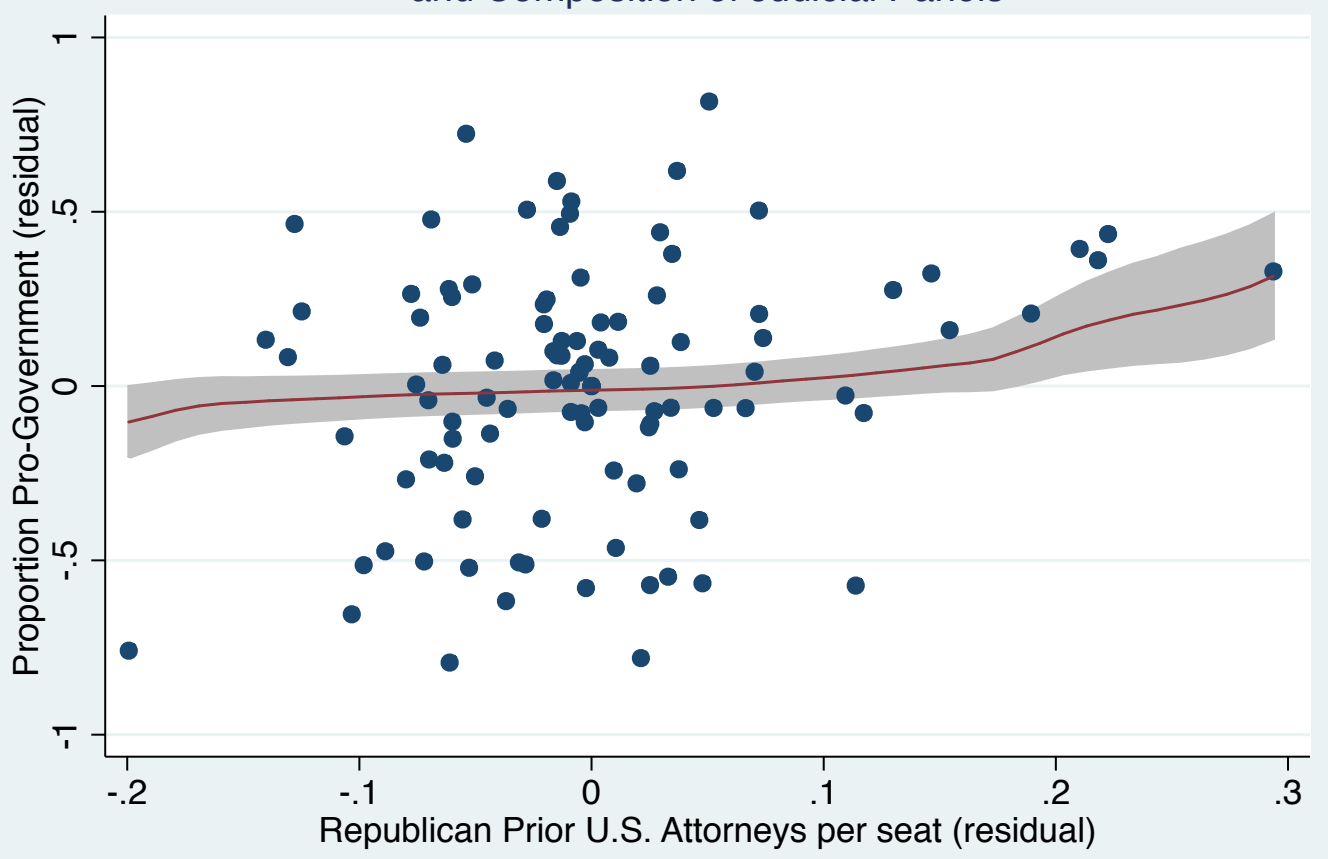

Nonparametric local polynomial estimates are computed using an Epanechnikov kernel. Rule-ofthumb bandwidth is used. Shaded area indicates 90 percent confidence bands. The residuals are calculated removing circuit and year fixed effects. 
Figure 5 - Number of Decisions

\section{Appellate Physical Takings Decisions, 1975-2008}

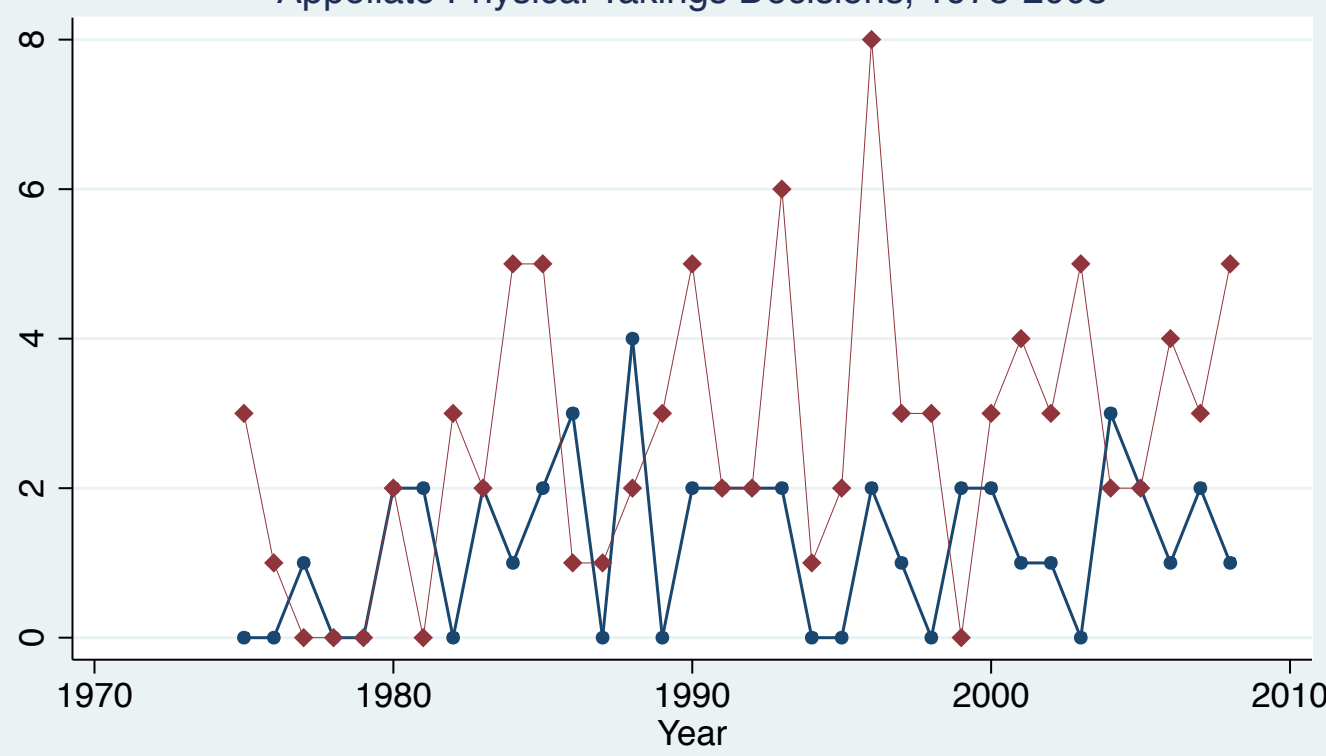

$\longrightarrow$ Number of Pro-Property Owner Takings Decisions Number of Pro-Government Takings Decisions

Appellate Physical Takings Decisions by Circuit, 1975-2008
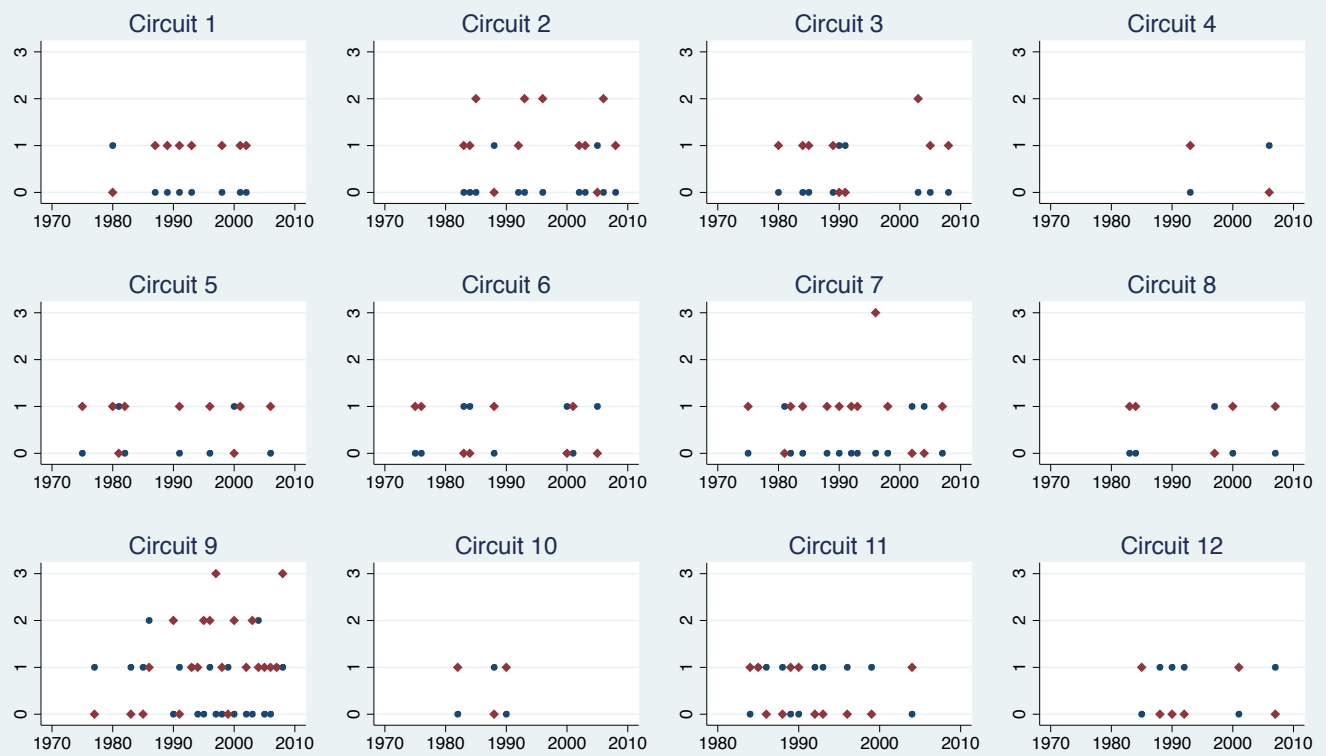

- Number of Pro-Property Owner Takings Decisions

- Number of Pro-Government Takings Decisions 


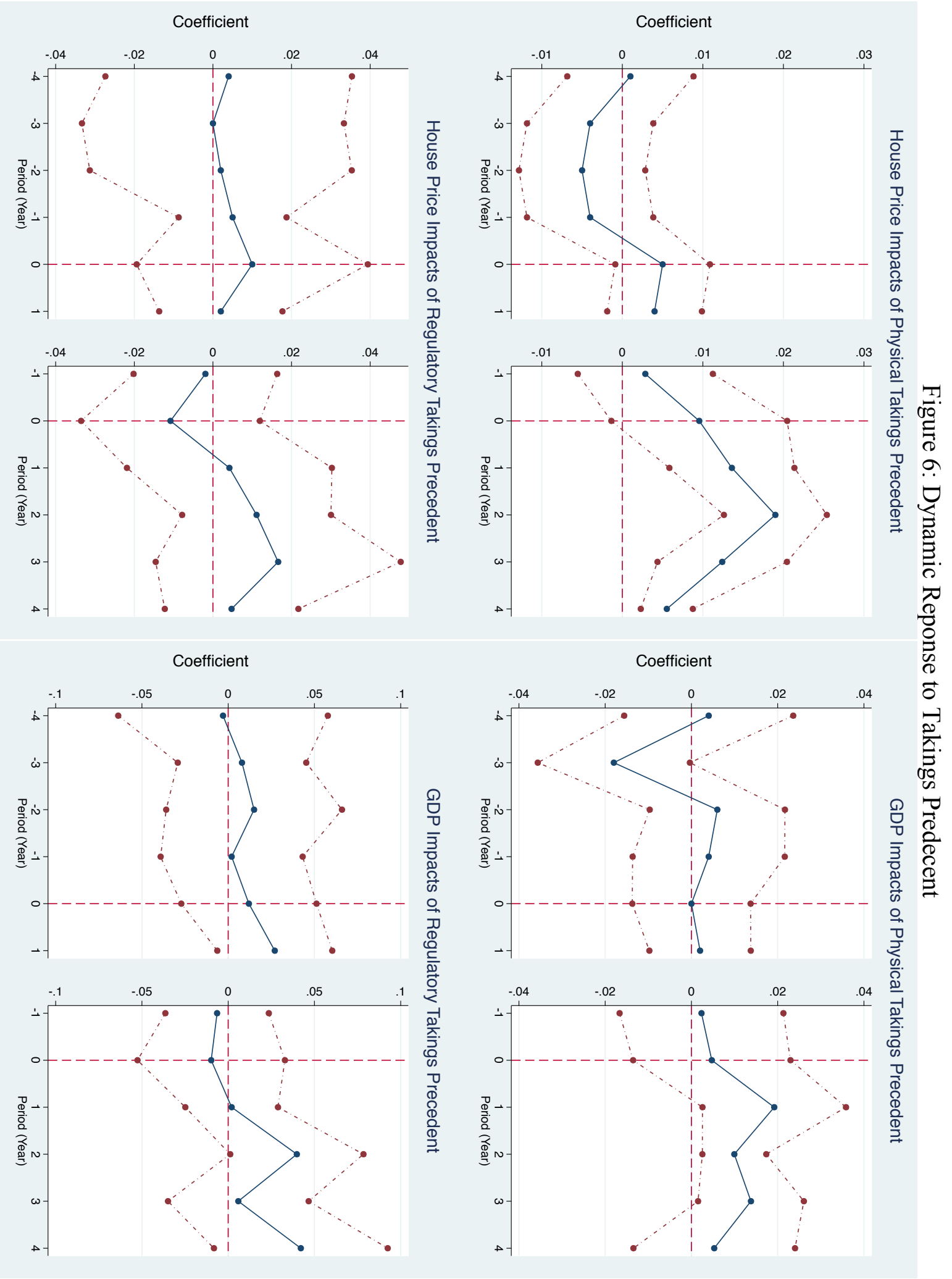


Figure 7: Perceived Takings Risk in Response to Eminent Domain Decisions

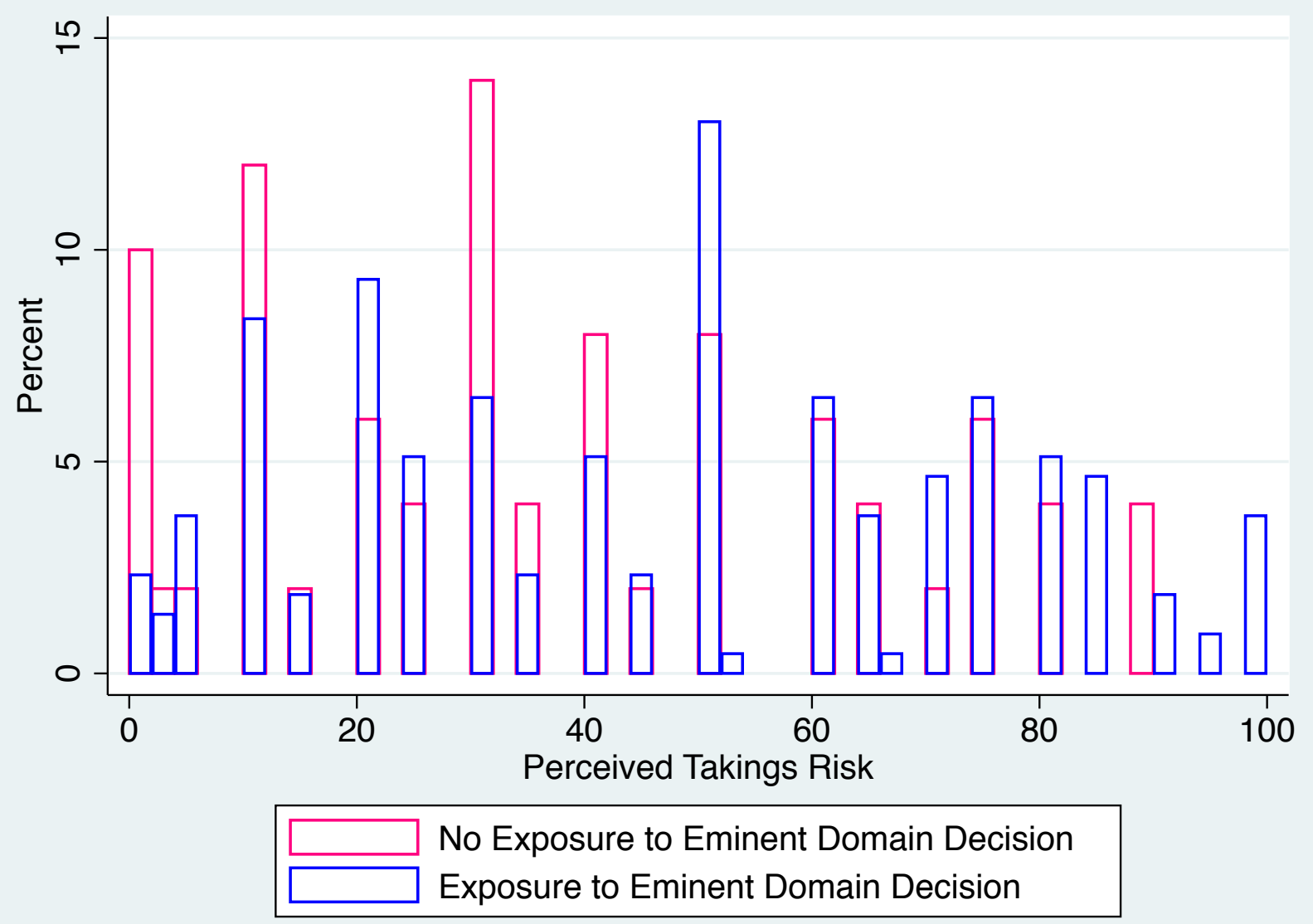


Case Name

U.S. v. Certain Parcels of Land in Fairfax County, of Va.

Anderson v. U.S.

District of Columbia Redevelopment Land Agency v. 61 Parcels of Land in Squares Richmond Inv. Co. v. U.S.

Donnelly v. District of Columbia Redevelopment Land Agency

Paper v. District of Columbia Redevelopment Land Agency

Mamer v. District of Columbia Redevelopment Land Agency

U.S. v. Mischke

Leeaye, Inc. v. District of Columbia Redevelopment Land Agency

Harrison-Halsted Community Group, Inc. v. Housing and Home Finance Agency Maiatico v. U.S.

U.S. v. Agee

Harwell v. U.S.

U.S. v. 91.69 Acres of Land, More or Less, in Oconee County, State of S. C.

U.S. v. Cobb

2,953.15 Acres of Land, More or Less, in Russell County, State of Ala. v. U.S.

Maun v. U.S.

Wilson v. U. S.

U.S. v. Bowman

Southern Pac. Land Co. v. U.S.

West, Inc. v. U.S.

Norwalk CORE v. Norwalk Redevelopment Agency

Scott Lumber Co. v. U.S.

Lake Charles Harbor and Terminal Dist. v. Henning

U.S. v. 2,606.84 Acres of Land in Tarrant County, Tex.

Woodland Market Realty Co. v. City of Cleveland

U.S. v. 3,317.39 Acres of Land, More or Less, in Jefferson County, Ark.

U.S. v. 80.5 Acres of Land, More or Less, in Shasta County, State of Cal.

U. S. ex rel. and for Use of Tennessee Val. Authority v. Two Tracts of Land U.S. v. 21.54 Acres of Land, More or Less, in Marshall County, State of W. Va. U.S. v. 6,321 Acres of Land More or Less In Suffolk County

U.S. v. 58.16 Acres of Land, More or Less In Clinton County, State of Ill.

U.S. v. 20.53 Acres of Land, More or Less, in Osborne County, Kansas

Gardner v. Nashville Housing Authority

U.S. v. 416.81 Acres of Land

Maher v. City of New Orleans

U.S. ex rel. Tennessee Val. Authority v. Two Tracts of Land

Richmond Elks Hall Ass'n v. Richmond Redevelopment Agency

Rogin v. Bensalem Tp.

U.S. v. 101.88 Acres of Land, More or Less, Situated in St. Mary Parish

John Donnelly \& Sons v. Campbell

Stansberry v. Holmes

Devines v. Maier

U.S. v. 162.20 Acres of Land, More or Less, Situated in Clay County

Barbian v. Panagis

National Western Life Ins. Co. v. Commodore Cove Imp. Dist.

U.S. v. 82.46 Acres of Land, More or Less, Situate in Carbon County, Wyo

Amen v. City of Dearborn

Lower Brule Sioux Tribe of South Dakota v. U.S.

Midkiff v. Tom

Kohl Indus. Park Co. v. Rockland County

Charles J. Arndt, Inc. v. City of Birmingham

Devines v. Maier

Park Ave. Tower Associates v. City of New York

Story v. Marsh

Troy Ltd. v. Renna

Hamilton Bank of Johnson City v. Williamson County Regional Planning Com'n

Robinson v. Ariyoshi

In re G. \& A. Books, Inc.

Rosenthal \& Rosenthal Inc. v. New York State Urban Development Corp.

Hilton Washington Corp. v. District of Columbia

Florida Power Corp. v. F.C.C.

Rymer v. Douglas County

Keystone Bituminous Coal Assn. v. Duncan

Henley v. Herring

Hall v. City of Santa Barbara

Martori Bros. Distributors v. James-Massengale

McMillan v. Goleta Water Dist.

Wood v. City of East Providence

A.A. Profiles, Inc. v. City of Ft. Lauderdale

Coniston Corp. v. Village of Hoffman Estates

Calvert Investments, Inc. v. Louisville and Jefferson County Metropolitan Sewer Alliance of American Insurers v. Cuomo

U.S. v. 2,560.00 Acres of Land, More or Less, Situate in Washington County National Wildlife Federation v. I.C.C.

Wendy's Intern., Inc. v. City of Birmingham

U.S. v. Frame
Circuit Year Pro-Property Owner

51956

121956

91957

121959

121960

121960

$8 \quad 1961$

121961

$7 \quad 1962$

121962

$\begin{array}{lll}6 & 1963\end{array}$

$\begin{array}{ll}10 & 1963\end{array}$

$\begin{array}{ll}4 & 1964\end{array}$

$\begin{array}{ll}9 & 1964\end{array}$

$\begin{array}{ll}5 & 1965\end{array}$

$\begin{array}{ll}9 & 1965\end{array}$

$10 \quad 1965$

71966

$\begin{array}{ll}9 & 1966\end{array}$

$\begin{array}{ll}5 & 1967\end{array}$

$\begin{array}{ll}2 & 1968\end{array}$

$\begin{array}{ll}9 & 1968\end{array}$

$\begin{array}{ll}5 & 1969\end{array}$

$\begin{array}{ll}5 & 1970\end{array}$

$\begin{array}{ll}6 & 1970\end{array}$

$\begin{array}{ll}8 & 1971\end{array}$

$\begin{array}{ll}9 & 1971\end{array}$

$\begin{array}{ll}6 & 1972\end{array}$

$\begin{array}{ll}4 & 1973\end{array}$

$\begin{array}{ll}1 & 1973\end{array}$

$\begin{array}{ll}7 & 1973\end{array}$

$10 \quad 1973$

$\begin{array}{ll}6 & 1975\end{array}$

$\begin{array}{ll}7 & 1975\end{array}$

$\begin{array}{ll}5 & 1975\end{array}$

$\begin{array}{ll}6 & 1976\end{array}$

$\begin{array}{ll}9 & 1977\end{array}$

31980

$\begin{array}{ll}5 & 1980\end{array}$

$\begin{array}{ll}1 & 1980\end{array}$

51980

$\begin{array}{ll}7 & 1981\end{array}$

$\begin{array}{ll}5 & 1981\end{array}$

$\begin{array}{ll}7 & 1982\end{array}$

$\begin{array}{ll}5 & 1982\end{array}$

$10 \quad 1982$

$\begin{array}{ll}6 & 1983\end{array}$

$\begin{array}{ll}8 & 1983\end{array}$

$\begin{array}{ll}9 & 1983\end{array}$

21983

$11 \quad 1984$

$\begin{array}{ll}7 & 1984\end{array}$

$\begin{array}{ll}2 & 1984\end{array}$

$\begin{array}{ll}8 & 1984\end{array}$

$\begin{array}{ll}3 & 1984\end{array}$

$\begin{array}{ll}6 & 1984\end{array}$

$\begin{array}{ll}9 & 1985\end{array}$

21985

21985

$12 \quad 1985$

$11 \quad 1985$

$\begin{array}{ll}11 & 1985\end{array}$

31985

$11 \quad 1986$

$\begin{array}{ll}9 & 1986\end{array}$

$\begin{array}{ll}9 & 1986\end{array}$

$\begin{array}{ll}9 & 1986\end{array}$

$\begin{array}{ll}1 & 1987\end{array}$

$11 \quad 1988$

$\begin{array}{ll}7 & 1988\end{array}$

$\begin{array}{ll}6 & 1988\end{array}$

$\begin{array}{ll}2 & 1988\end{array}$

$\begin{array}{ll}10 & 1988\end{array}$

$\begin{array}{ll}12 & 1988\end{array}$

$11 \quad 1989$

$\begin{array}{ll}3 & 1989\end{array}$

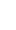
( (1) ( 1 (1) 0 1

0

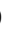

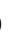
0 . 1 0

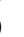
0 0 0 0

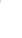
1 0 1 0 1 1 1 0 1 0 
Citation

889 F.2d 1181

898 F.2d 347

911 F.2d 743

912 F.2d 467

900 F.2d 1434

922 F.2d 498

902 F.2d 905

919 F.2d 593

932 F.2d 51

940 F.2d 925

948 F.2d 575

945 F.2d 594

978 F.2d 1269

953 F.2d 600

956 F.2d 670

980 F.2d 84

985 F.2d 573

997 F.2d 1369

998 F.2d 680

6 F.3d 867

993 F.2d 962

987 F.2d 913

991 F.2d 1169

5 F. $3 \mathrm{~d} 285$

37 F.3d 468

53 F.3d 338

57 F.3d 781

95 F.3d 1422

101 F.3d 1095

83 F.3d 45

107 F.3d 3 (Table)

84 F.3d 865

85 F.3d 422

87 F.3d 290

89 F.3d 1481

93 F.3d 301

95 F.3d 1359

105 F.3d 1281

124 F.3d 1150

112 F.3d 313

109 F.3d 1493

153 F.3d 356

147 F.3d 802

160 F.3d 834

165 F.3d 692

187 F.3d 1324

214 F.3d 573

216 F.3d 764

230 F.3d 355

224 F.3d 1030

226 F.3d 758

31 Fed.Appx. 159

266 F.3d 487

254 F.3d 89

267 F.3d 45

270 F.3d 180

285 F.3d 142

31 Fed.Appx. 19

288 F.3d 375

306 F.3d 445

353 F.3d 651

344 F.3d 959

57 Fed.Appx. 939

316 F.3d 308

342 F.3d 222

97 Fed.Appx. 698

374 F.3d 887

366 F.3d 1186

361 F.3d 934

363 F.3d 846

411 F.3d 697

419 F.3d 1036

143 Fed.Appx. 439

434 F.3d 121

464 F.3d 362

464 F.3d 480
Case Name

Duty Free Shop, Inc. v. Administracion De Terrenos De Puerto Rico

Pinewood Estates of Michigan v. Barnegat Tp. Leveling Bd.

Boston and Maine Corp. v. I.C.C.

Kurr v. Village of Buffalo Grove

Oberndorf v. City and County of Denver

Southern Pacific Transp. Co. v. City of Los Angeles

Centel Cable Television Co. of Florida v. Thomas J. White Development Corp.

Mountain Water Co. v. Montana Dept. of Public Service Regulation

Gilbert v. City of Cambridge

Samaad v. City of Dallas

Azul Pacifico, Inc. v. City of Los Angeles

Hughes v. Consol-Pennsylvania Coal Co.

Nixon v. U.S.

Cable Holdings of Georgia, Inc. v. McNeil Real Estate Fund VI, Ltd.

Rose Acre Farms, Inc. v. Madigan

Southview Associates, Ltd. v. Bongartz

Pacific Power and Light Co. v. Surprise Valley Electrification Corp.

Corn v. City of Lauderdale Lakes

Levald, Inc. v. City of Palm Desert

AMSAT Cable Ltd. v. Cablevision of Connecticut Ltd. Partnership

Washington Legal Foundation v. Massachusetts Bar Foundation

Garelick v. Sullivan

Media General Cable of Fairfax, Inc. v. Sequoyah Condominium Council of Co-Owners

Gamble v. Eau Claire County

Carson Harbor Village Ltd. v. City of Carson

Karagozian v. City of Laguna Beach

Hoeck v. City of Portland

Del Monte Dunes at Monterey, Ltd. v. City of Monterey

Texas Manufactured Housing Ass'n, Inc. v. City of Nederland

Federal Home Loan Mortg. Corp. v. New York State Div. of Housing and Community

October Twenty-Four, Inc. v. Town of Plainville

Hager v. City of West Peoria

Broad v. Sealaska Corp.

Fireman's Fund Ins. Co. v. Quackenbush

Bickerstaff Clay Products Co., Inc. v. Harris County, Ga. By and Through Bd.

Porter v. DiBlasio

Wisconsin Cent. Ltd. v. Public Service Com'n of Wisconsin

Bay View, Inc. on behalf of AK Native Village Corporations v. Ahtna, Inc.

Richardson v. City and County of Honolulu

McKenzie v. City of White Hall

U.S. v. 0.59 Acres of Land

International College of Surgeons v. City of Chicago

Garneau v. City of Seattle

South County Sand \& Gravel Co., Inc. v. Town of South Kingstown

Thomas v. Anchorage Equal Rights Com'n

Gulf Power Co. v. U.S.

John Corp. v. City of Houston

Tahoe-Sierra Preservation Council, Inc. v. Tahoe Regional Planning Agency

Milligan v. City of Red Oak, Iowa

Chevron USA, Inc. v. Cayetano

Montgomery v. Carter County, Tennessee

Kamman Inc. v. City of Hewitt

Anderson v. Charter Tp. of Ypsilanti

Building Owners and Managers Ass'n Intern. v. F.C.C.

Philip Morris, Inc. v. Reilly

Washington Legal Foundation v. Texas Equal Access to Justice Foundation

Deniz v. Municipality of Guaynabo

West 95 Housing Corp. v. New York City Dept. of Housing Preservation

Daniel v. County of Santa Barbara

Daniels v. Area Plan Com'n of Allen County

Hacienda Valley Mobile Estates v. City of Morgan Hill

Hotel \& Motel Ass'n of Oakland v. City of Oakland

Jones v. Philadelphia Police Dept.

Tancredi v. Metropolitan Life Ins. Co.

Borough of Columbia v. Surface Transp. Bd.

Los Altos El Granada Investors v. City of Capitola

Cashman v. City of Cotati

Garvie v. City of Ft. Walton Beach, Fla.

Greenfield Mills, Inc. v. Macklin

Chevron USA, Inc. v. Bronster

Warren v. City of Athens, Ohio

M\&A Gabaee v. Community Redevelopment Agency of City of Los Angeles

Ash v. Redevelopment Authority of Philadelphia

Brody v. Village of Port Chester

Buffalo Teachers Federation v. Tobe

Presley v. City Of Charlottesville
Circuit Year Pro-Property Owner

11989

31990

121990

$\begin{array}{ll}7 & 1990\end{array}$

$10 \quad 1990$

$9 \quad 1990$

$11 \quad 1990$

$\begin{array}{ll}9 & 1990\end{array}$

11991

$\begin{array}{ll}5 & 1991\end{array}$

$\begin{array}{ll}9 & 1991\end{array}$

$\begin{array}{ll}3 & 1991\end{array}$

$\begin{array}{ll}12 & 1992\end{array}$

$11 \quad 1992$

$\begin{array}{ll}7 & 1992\end{array}$

21992

$\begin{array}{ll}9 & 1993\end{array}$

$11 \quad 1993$

$\begin{array}{ll}9 & 1993\end{array}$

21993

$\begin{array}{ll}1 & 1993\end{array}$

21993

$\begin{array}{ll}4 & 1993\end{array}$

$\begin{array}{ll}7 & 1993\end{array}$

$\begin{array}{ll}9 & 1994\end{array}$

$\begin{array}{ll}9 & 1995\end{array}$

$\begin{array}{ll}9 & 1995\end{array}$

91996

$\begin{array}{ll}5 & 1996\end{array}$

21996

21996

71996

91996

91996

$11 \quad 1996$

$\begin{array}{ll}7 & 1996\end{array}$

$7 \quad 1996$

$\begin{array}{ll}9 & 1997\end{array}$

$\begin{array}{ll}9 & 1997\end{array}$

$\begin{array}{ll}8 & 1997\end{array}$

$\begin{array}{ll}9 & 1997\end{array}$

$\begin{array}{ll}7 & 1998\end{array}$

$\begin{array}{ll}9 & 1998\end{array}$

$\begin{array}{ll}1 & 1998\end{array}$

$\begin{array}{ll}9 & 1999\end{array}$

$\begin{array}{ll}11 & 1999\end{array}$

52000

92000

$8 \quad 2000$

$\begin{array}{ll}9 & 2000\end{array}$

62000

$\begin{array}{ll}5 & 2001\end{array}$

$6 \quad 2001$

122001

12001

52001

12002

22002

92002

$7 \quad 2002$
9

92003

$\begin{array}{ll}9 & 2003\end{array}$

32003

22003

32003

$9 \quad 2004$

$9 \quad 2004$

$11 \quad 2004$

$\begin{array}{ll}7 & 2004\end{array}$

$9 \quad 2004$

62005

$9 \quad 2005$

32005

22005

22006

$4 \quad 2006$

0

0

0 0

,

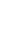

0

0

0

(

0

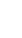

0

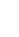

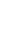

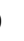


202 Fed.Appx. 670 Western Seafood Co. v. U.S.

173 Fed.Appx. 931 Didden v. Village of Port Chester

22006

U.S. v. 1,402 Acres of Land

502 F.3d 616

St. John's United Church of

509 F.3d 1020

92006

72007

Action Apartment Ass'n, Inc. v. Santa Monica Rent Control Bd.

92007

474 F.3d 528

Cormack v. Settle-Beshears

$8 \quad 2007$

487 F.3d 941

497 F.3d 902

Rumber v. District of Columbia

516 F.3d 50

Vacation Village, Inc. v. Clark County, Nev

Goldstein v. Pataki

2008 WL 2225684 Surf and Sand, LLC v. City of Capitola

122007

92007

22008

92008

289 Fed.Appx. 232

547 F.3d 943

Besaro Mobile Home Park, LLC v. City of Fremont

512 F.3d 1148

U.S. v. 14.02 Acres of Land More or Less in Fresno County

92008

Matsuda v. City and County of Honolulu

92008

92008

550 F.3d 302

Carole Media LLC v. New Jersey Transit Corp.

32008 
Appendix Table 2 - Randomization Check

\begin{tabular}{|c|c|c|c|c|c|}
\hline \multicolumn{6}{|c|}{ Panel A: P-Values from Kolmogorov Smirnov Test for Deviations from Uniform CDF } \\
\hline \multicolumn{6}{|c|}{ Physical Takings (Racial Minority Democrat Appointees) } \\
\hline & distance & size & $90 \%$ & $95 \%$ & $99 \%$ \\
\hline Autocorrelation & 0.180666667 & 9 & 0.3392 & 0.3874 & 0.4795 \\
\hline Mean Reversion & 0.318 & 8 & 0.3583 & 0.4097 & 0.5068 \\
\hline \multirow[t]{3}{*}{ Longest Run } & 0.200888889 & 9 & 0.3392 & 0.3874 & 0.4795 \\
\hline & Regulatory Takin & ses wi & res of w & ed or bet & \\
\hline & distance & size & $90 \%$ & $95 \%$ & $99 \%$ \\
\hline Autocorrelation & 0.218333333 & 12 & 0.2958 & 0.3382 & 0.4192 \\
\hline Mean Reversion & 0.215333333 & 12 & 0.2958 & 0.3382 & 0.4192 \\
\hline Longest Run & 0.179 & 11 & 0.3083 & 0.3524 & 0.4367 \\
\hline
\end{tabular}

Panel B: Falsification Test of Instrument: Relationship Between Pro-Government Takings Decisions and Composition of Takings Panels in Other Years, 1975-2008

\begin{tabular}{lcccc}
\hline Circuit-Year Level & Outcome: Proportion of Pro-Government Physical Takings Decisions & $(3)$ \\
& $(1)$ & $(2)$ & $(3)$ & $(4)$ \\
\hline Racial Minority Democratic & -0.701 & -0.645 & -0.694 & -0.684 \\
Appointees per Seat & $(0.220)$ & $(0.240)$ & $(0.211)$ & $(0.225)$ \\
Racial Minority Democratic & 0.554 & 0.535 & & \\
Appointees per Seat & & $(0.362)$ & & \\
Racial Minority Democratic & $(0.370)$ & -0.525 & & \\
$\quad$ Appointees per Seat & & $(0.276)$ & & -0.0824 \\
Racial Minority Democratic & & & -0.0788 & $(0.394)$ \\
Appointees per Seat & & & $(0.398)$ & 0.306 \\
Racial Minority Democratic & & & & $(0.581)$ \\
Appointees per Seat & & & & 100 \\
N & & 103 & 104 & 0.057 \\
R-sq & 104 & 0.089 & 0.064 & \\
\hline
\end{tabular}

\begin{tabular}{|c|c|c|c|c|}
\hline \multirow[t]{2}{*}{ Circuit-Year Level } & \multicolumn{4}{|c|}{ Outcome: Proportion of Pro-Government Regulatory Takings Decisions ${ }_{t}$} \\
\hline & $(5)$ & $(6)$ & $(7)$ & $(8)$ \\
\hline Judges with ABA scores of well- & 0.335 & 0.328 & 0.261 & 0.262 \\
\hline qualified or better per Seat & $(0.139)$ & $(0.153)$ & $(0.154)$ & $(0.157)$ \\
\hline Judges with ABA scores of well- & -0.164 & -0.159 & & \\
\hline qualified or better per Seat $t_{\mathrm{t}-1}$ & $(0.0912)$ & $(0.0913)$ & & \\
\hline Judges with ABA scores of well- & & 0.0287 & & \\
\hline qualified or better per Seat $_{\mathrm{t}-2}$ & & $(0.137)$ & & \\
\hline Judges with ABA scores of well- & & & 0.0115 & 0.00911 \\
\hline qualified or better per Seat $t_{t+1}$ & & & $(0.101)$ & $(0.106)$ \\
\hline Judges with ABA scores of well- & & & & -0.00270 \\
\hline qualified or better per Seat $t_{t+2}$ & & & & $(0.111)$ \\
\hline $\mathrm{N}$ & 142 & 137 & 137 & 135 \\
\hline R-sq & 0.217 & 0.208 & 0.209 & 0.207 \\
\hline
\end{tabular}

Notes: Heteroskedasticity-robust standard errors are in parentheses. Observations are clustered at the Circuit level. Proportions of pro-government takings decisions are set to missing in Circuit-years with no cases. 


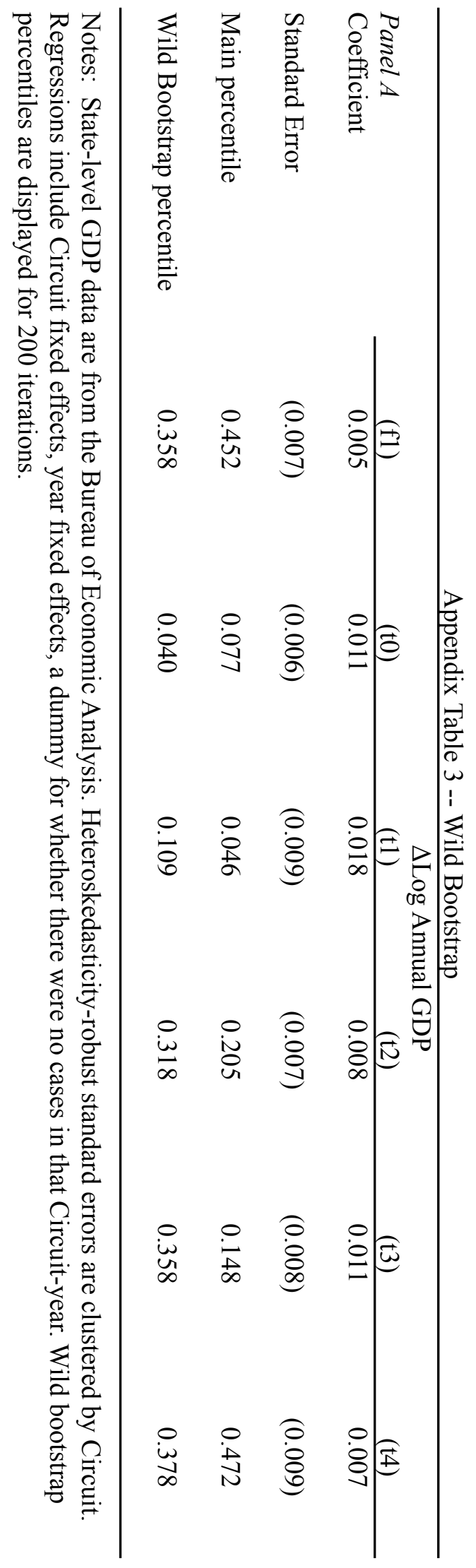




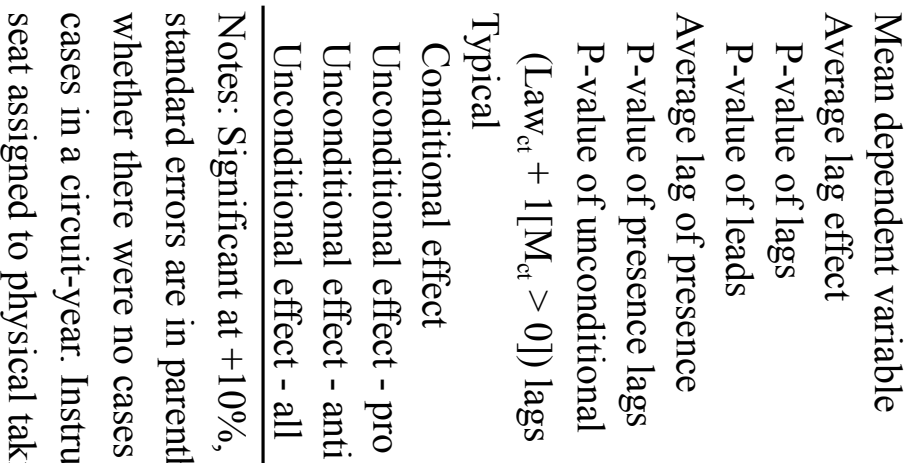

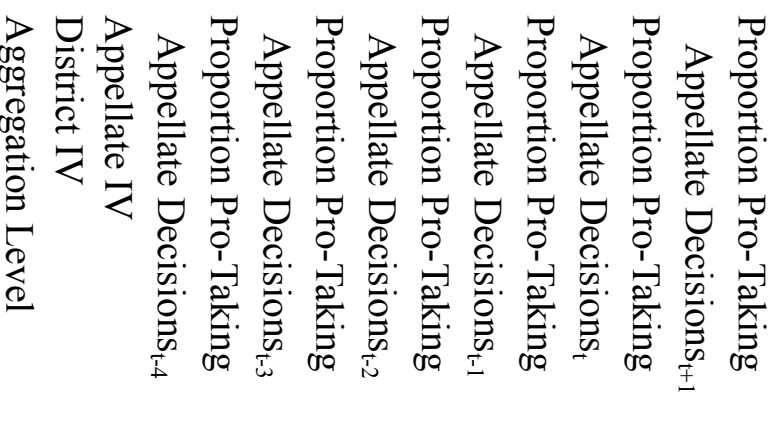

言.

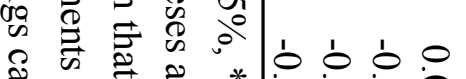

苞

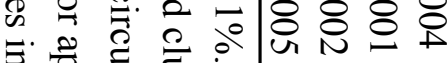

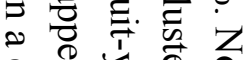

อ.

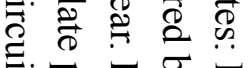

ㄷ. $=0$

난

ه

¿

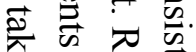

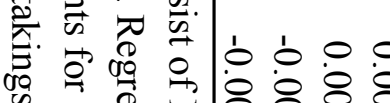

品

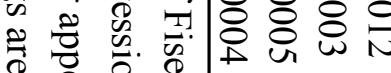

$\odot \stackrel{0}{\circ}$

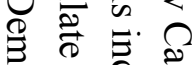

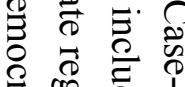

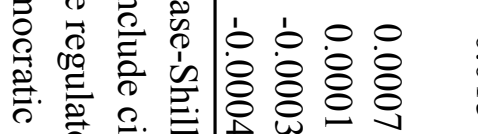

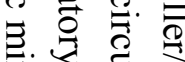

학

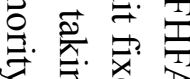

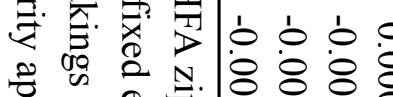

艺

㝵

बे

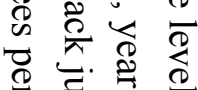

$\rightarrow$ I 0

प व

$\stackrel{8}{\circ}$ \&

芑 Ф

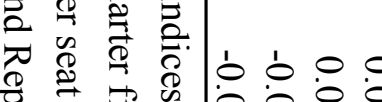

च

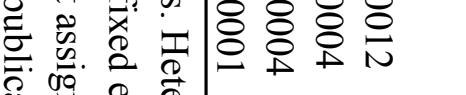

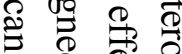

ㄱ.

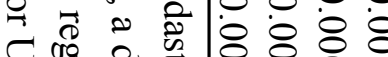

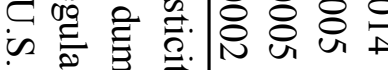

〉苛

永娄交

蛋

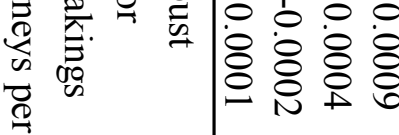

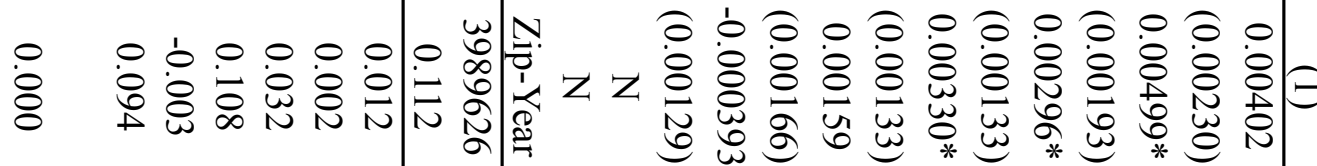

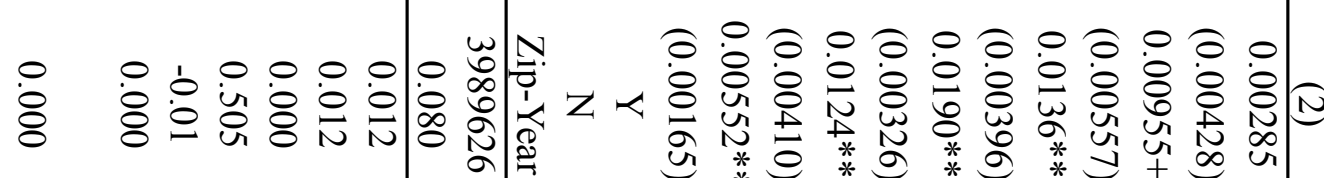

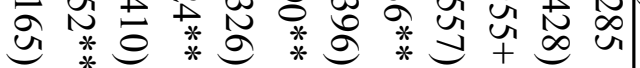

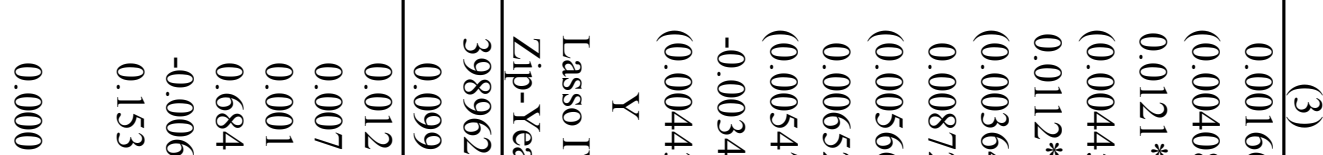

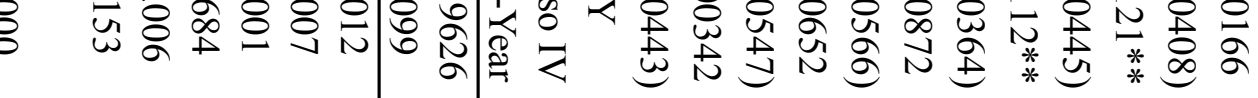

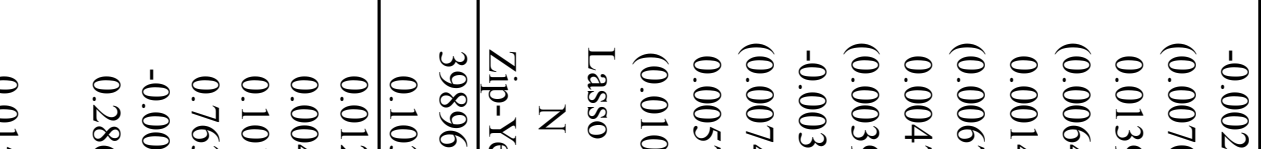

u 


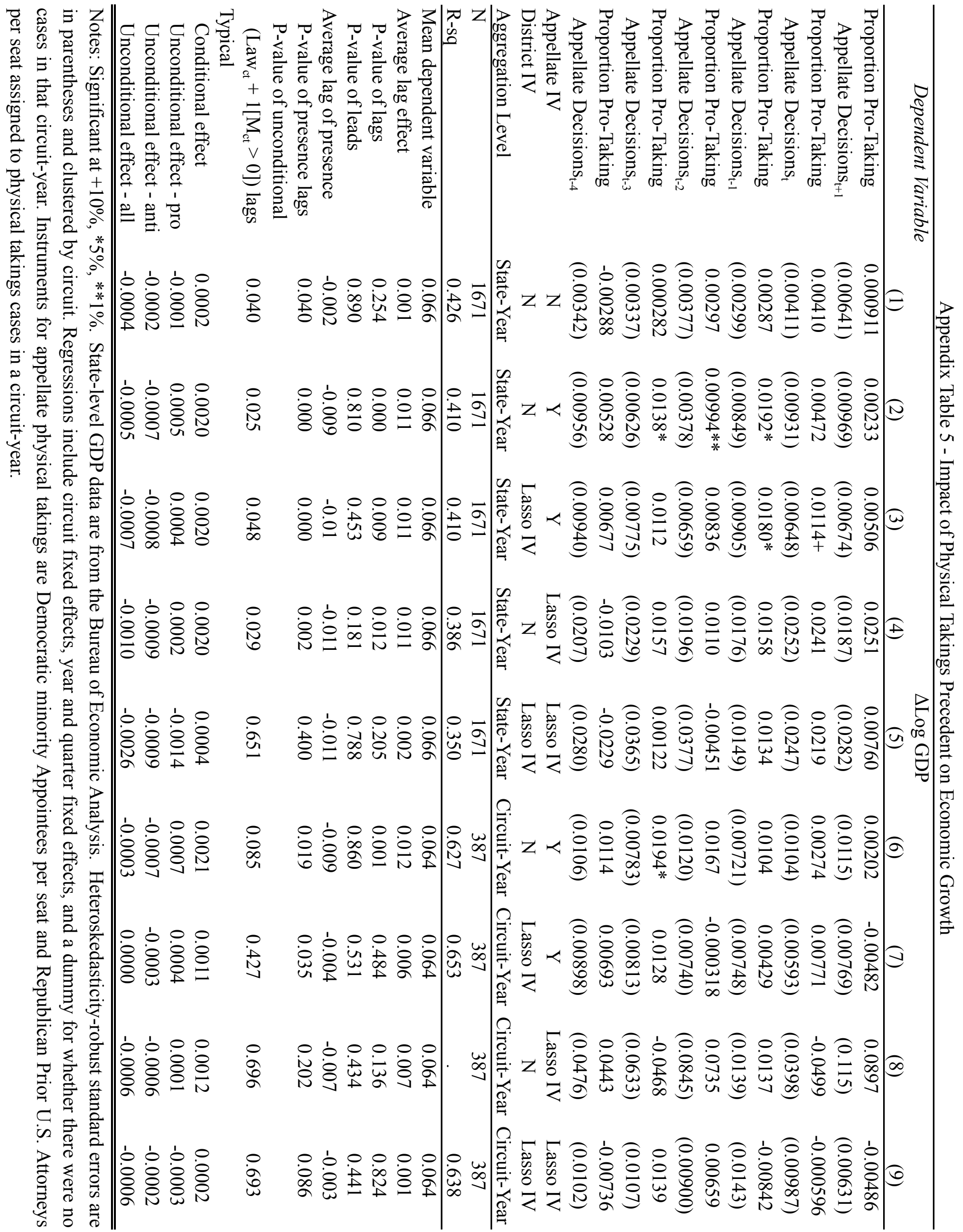


Appendix Table 6 -- Impact of Physical Takings Precedent on Growth -- Robustness of IV Estimates Across Controls

\begin{tabular}{|c|c|c|c|}
\hline & \multicolumn{3}{|c|}{ The Effect of Appellate Physical Takings Precedent on $\Delta$ Log GDP } \\
\hline & $\begin{array}{c}\text { Average of yearly lags } \\
\text { (1) }\end{array}$ & $\begin{array}{l}\text { P-value of lags } \\
\text { (2) }\end{array}$ & $\begin{array}{c}\text { P-value of leads } \\
\text { (3) }\end{array}$ \\
\hline A. Add Circuit-Specific Trends & 0.008 & 0.011 & 0.894 \\
\hline B. No Fixed Effects & 0.001 & 0.031 & 0.903 \\
\hline C. State Cluster & 0.011 & 0.002 & 0.763 \\
\hline D. Control for Expectation & 0.013 & 0.002 & 0.556 \\
\hline E. Use Population Weights & 0.009 & 0.000 & 0.683 \\
\hline \multicolumn{4}{|l|}{ F. Drop 1 Circuit } \\
\hline Circuit 1 & 0.010 & 0.001 & 0.767 \\
\hline Circuit 2 & 0.008 & 0.000 & 0.465 \\
\hline Circuit 3 & 0.012 & 0.000 & 0.601 \\
\hline Circuit 4 & 0.010 & 0.000 & 0.932 \\
\hline Circuit 5 & 0.011 & 0.001 & 0.644 \\
\hline Circuit 6 & 0.009 & 0.000 & 0.566 \\
\hline Circuit 7 & 0.008 & 0.004 & 0.759 \\
\hline Circuit 8 & 0.010 & 0.000 & 0.812 \\
\hline Circuit 9 & 0.025 & 0.000 & 0.451 \\
\hline Circuit 10 & 0.012 & 0.000 & 0.422 \\
\hline Circuit 11 & 0.011 & 0.000 & 0.740 \\
\hline Circuit 12 & 0.010 & 0.000 & 0.824 \\
\hline
\end{tabular}

Notes: Significant at $+10 \%, * 5 \%, * * 1 \%$. State-level GDP data are from the Bureau of Economic Analysis. Heteroskedasticity-robust standard errors are in parentheses and clustered by circuit. Regressions include circuit fixed effects, year and quarter fixed effects, a dummy for whether there were no cases in that circuit-year. The baseline regression is an instrumental variables specification with one lead and four lags of appellate physical takings precedent. Instruments for appellate physical takings are Democratic minority Appointees per seat and Republican Prior U.S. Attorneys per seat assigned to appellate physical takings cases in a circuit-year. Expectation controls are the expected probability of being assigned a Democratic minority appointee per seat and a Republic prior U.S. Attorney per seat in a circuit-year. Population weights are based on the 2005 US Census estimates at the zip-code level. 
Appendix Table 7 -- Impact of Physical Takings Precedent on Growth

Robustness of IV Distributed Lag Estimates Across Controls, Lag Structure, and Leads

The Effect of Appellate Physical Takings Precedent on $\Delta$ Log GDP

\begin{tabular}{|c|c|c|c|c|c|c|}
\hline & $(\mathrm{t} 0)$ & $(\mathrm{t} 1)$ & $(\mathrm{t} 2)$ & $(\mathrm{t} 3)$ & $(\mathrm{t} 4)$ & $(\mathrm{t} 5)$ \\
\hline A. Add Circuit-Specific Trends & $\begin{array}{c}0.002 \\
(0.008)\end{array}$ & $\begin{array}{l}0.015 * \\
(0.008)\end{array}$ & $\begin{array}{l}0.008+ \\
(0.004)\end{array}$ & $\begin{array}{l}0.013+ \\
(0.007)\end{array}$ & $\begin{array}{c}0.003 \\
(0.009)\end{array}$ & \\
\hline B. No Fixed Effects & $\begin{array}{l}-0.017 \\
(0.022)\end{array}$ & $\begin{array}{c}-0.005 \\
(0.006)\end{array}$ & $\begin{array}{c}0.019^{*} \\
(0.009)\end{array}$ & $\begin{array}{c}0.012 \\
(0.015)\end{array}$ & $\begin{array}{c}-0.004 \\
(0.008)\end{array}$ & \\
\hline C. State Cluster & $\begin{array}{c}0.005 \\
(0.009)\end{array}$ & $\begin{array}{l}0.019 * \\
(0.008)\end{array}$ & $\begin{array}{l}0.010+ \\
(0.005)\end{array}$ & $\begin{array}{l}0.014 * \\
(0.006)\end{array}$ & $\begin{array}{c}0.005 \\
(0.007)\end{array}$ & \\
\hline D. Control for Expectation & $\begin{array}{c}0.006 \\
(0.012)\end{array}$ & $\begin{array}{l}0.023 * \\
(0.009)\end{array}$ & $\begin{array}{c}0.013 * * \\
(0.005)\end{array}$ & $\begin{array}{l}0.015 * \\
(0.007)\end{array}$ & $\begin{array}{c}0.008 \\
(0.011)\end{array}$ & \\
\hline E. Use Population Weights & $\begin{array}{c}-0.001 \\
(0.008)\end{array}$ & $\begin{array}{l}0.014+ \\
(0.008)\end{array}$ & $\begin{array}{l}0.016+ \\
(0.009)\end{array}$ & $\begin{array}{c}0.015 * * \\
(0.004)\end{array}$ & $\begin{array}{c}0.003 \\
(0.007)\end{array}$ & \\
\hline \multicolumn{7}{|l|}{ F. Drop 1 Circuit } \\
\hline Drop Circuit 1 & $\begin{array}{c}0.001 \\
(0.010)\end{array}$ & $\begin{array}{l}0.019^{*} \\
(0.009)\end{array}$ & $\begin{array}{c}0.010^{* *} \\
(0.004)\end{array}$ & $\begin{array}{l}0.012 * \\
(0.006)\end{array}$ & $\begin{array}{c}0.005 \\
(0.010)\end{array}$ & \\
\hline Drop Circuit 2 & $\begin{array}{l}-0.002 \\
(0.008)\end{array}$ & $\begin{array}{l}0.019+ \\
(0.010)\end{array}$ & $\begin{array}{c}0.011 * * \\
(0.004)\end{array}$ & $\begin{array}{c}0.011 * * \\
(0.004)\end{array}$ & $\begin{array}{c}0.003 \\
(0.010)\end{array}$ & \\
\hline Drop Circuit 3 & $\begin{array}{c}0.008 \\
(0.010)\end{array}$ & $\begin{array}{l}0.021 * \\
(0.009)\end{array}$ & $\begin{array}{l}0.010 * \\
(0.004)\end{array}$ & $\begin{array}{l}0.017 * \\
(0.007)\end{array}$ & $\begin{array}{c}0.004 \\
(0.009)\end{array}$ & \\
\hline Drop Circuit 4 & $\begin{array}{c}0.004 \\
(0.011)\end{array}$ & $\begin{array}{l}0.019 * \\
(0.009)\end{array}$ & $\begin{array}{c}0.009 * \\
(0.004)\end{array}$ & $\begin{array}{l}0.014 * \\
(0.006)\end{array}$ & $\begin{array}{c}0.005 \\
(0.010)\end{array}$ & \\
\hline Drop Circuit 5 & $\begin{array}{c}0.006 \\
(0.009)\end{array}$ & $\begin{array}{c}0.024 * * \\
(0.007)\end{array}$ & $\begin{array}{l}0.008 * \\
(0.004)\end{array}$ & $\begin{array}{l}0.011+ \\
(0.006)\end{array}$ & $\begin{array}{c}0.007 \\
(0.009)\end{array}$ & \\
\hline Drop Circuit 6 & $\begin{array}{c}0.002 \\
(0.010)\end{array}$ & $\begin{array}{l}0.019 * \\
(0.009)\end{array}$ & $\begin{array}{c}0.013 * * \\
(0.004)\end{array}$ & $\begin{array}{l}0.012 * \\
(0.006)\end{array}$ & $\begin{array}{c}0.002 \\
(0.009)\end{array}$ & \\
\hline Drop Circuit 7 & $\begin{array}{c}0.004 \\
(0.011)\end{array}$ & $\begin{array}{c}0.011 * \\
(0.005)\end{array}$ & $\begin{array}{c}0.008+ \\
(0.005)\end{array}$ & $\begin{array}{l}0.015 * \\
(0.007)\end{array}$ & $\begin{array}{c}0.003 \\
(0.009)\end{array}$ & \\
\hline Drop Circuit 8 & $\begin{array}{c}0.008 \\
(0.009)\end{array}$ & $\begin{array}{l}0.015+ \\
(0.008)\end{array}$ & $\begin{array}{c}0.008+ \\
(0.005)\end{array}$ & $\begin{array}{l}0.013+ \\
(0.007)\end{array}$ & $\begin{array}{c}0.004 \\
(0.009)\end{array}$ & \\
\hline Drop Circuit 9 & $\begin{array}{c}0.010 \\
(0.016)\end{array}$ & $\begin{array}{c}0.021 \\
(0.015)\end{array}$ & $\begin{array}{l}0.033 * \\
(0.015)\end{array}$ & $\begin{array}{c}0.031 \\
(0.023)\end{array}$ & $\begin{array}{c}0.030 * * \\
(0.009)\end{array}$ & \\
\hline Drop Circuit 10 & $\begin{array}{c}0.006 \\
(0.008)\end{array}$ & $\begin{array}{c}0.020 * * \\
(0.007)\end{array}$ & $\begin{array}{c}0.012 * * \\
(0.004)\end{array}$ & $\begin{array}{c}0.014 * * \\
(0.005)\end{array}$ & $\begin{array}{c}0.008 \\
(0.008)\end{array}$ & \\
\hline Drop Circuit 11 & $\begin{array}{c}0.006 \\
(0.010)\end{array}$ & $\begin{array}{l}0.021 * \\
(0.009)\end{array}$ & $\begin{array}{l}0.009 * \\
(0.004)\end{array}$ & $\begin{array}{l}0.014 * \\
(0.007)\end{array}$ & $\begin{array}{c}0.006 \\
(0.010)\end{array}$ & \\
\hline Drop Circuit 12 & $\begin{array}{c}0.003 \\
(0.010)\end{array}$ & $\begin{array}{l}0.020 * \\
(0.009)\end{array}$ & $\begin{array}{c}0.010 * * \\
(0.004)\end{array}$ & $\begin{array}{l}0.014^{*} \\
(0.006)\end{array}$ & $\begin{array}{c}0.004 \\
(0.009)\end{array}$ & \\
\hline G. Lag Structure & & & & & & \\
\hline $1 \mathrm{Lag}$ & $\begin{array}{c}-0.003 \\
(0.009)\end{array}$ & $\begin{array}{c}0.007 \\
(0.007)\end{array}$ & & & & \\
\hline 2 Lags & $\begin{array}{c}-0.006 \\
(0.008)\end{array}$ & $\begin{array}{l}0.013 * \\
(0.006)\end{array}$ & $\begin{array}{c}0.009 \\
(0.008)\end{array}$ & & & \\
\hline 2 Leads, 4 Lags & $\begin{array}{c}0.005 \\
(0.010)\end{array}$ & $\begin{array}{l}0.018+ \\
(0.010)\end{array}$ & $\begin{array}{l}0.010^{*} \\
(0.005)\end{array}$ & $\begin{array}{l}0.014 * * \\
(0.005)\end{array}$ & $\begin{array}{c}0.005 \\
(0.009)\end{array}$ & \\
\hline 1 Lead, 5 Lags & $\begin{array}{l}-0.000 \\
(0.008)\end{array}$ & $\begin{array}{l}0.020 * * \\
(0.008)\end{array}$ & $\begin{array}{l}0.018 * * \\
(0.004)\end{array}$ & $\begin{array}{l}0.017^{*} \\
(0.006)\end{array}$ & $\begin{array}{c}0.004 \\
(0.009)\end{array}$ & $\begin{array}{c}0.005 \\
(0.005)\end{array}$ \\
\hline $\begin{array}{l}4 \text { Leads, } 1 \text { Lag } \\
(\mathrm{t} 0, \mathrm{t} 1, \mathrm{f} 4, \mathrm{f} 3, \mathrm{f} 2, \mathrm{f} 1)\end{array}$ & $\begin{array}{l}-0.000 \\
(0.007)\end{array}$ & $\begin{array}{c}0.002 \\
(0.006)\end{array}$ & $\begin{array}{c}0.004 \\
(0.010)\end{array}$ & $\begin{array}{l}-0.018 * \\
(0.009)\end{array}$ & $\begin{array}{c}0.006 \\
(0.008)\end{array}$ & $\begin{array}{c}0.004 \\
(0.009)\end{array}$ \\
\hline
\end{tabular}

Notes: Significant at $+10 \%, * 5 \%, * * 1 \%$. State-level GDP data are from the Bureau of Economic Analysis. Heteroskedasticity-robust standard errors are in parentheses and clustered by circuit. Regressions include circuit fixed effects, year and quarter fixed effects, and a dummy for whether there were no cases in that circuit-year. The baseline regression is an instrumental variables specification with one lead and four lags of appellate physical takings precedent. Coefficients on the lags are shown here. Instruments for appellate physical takings are Democratic minority Appointees per seat and Republican Prior U.S. Attorneys per seat assigned to appellate physical takings cases in a circuit-year. Expectation controls are the expected probability of being assigned a Democratic minority appointee per seat and a Republic prior U.S. Attorney per seat in a circuit-year. Population weights are based on the 2005 US Census estimates at the zip-code level. 


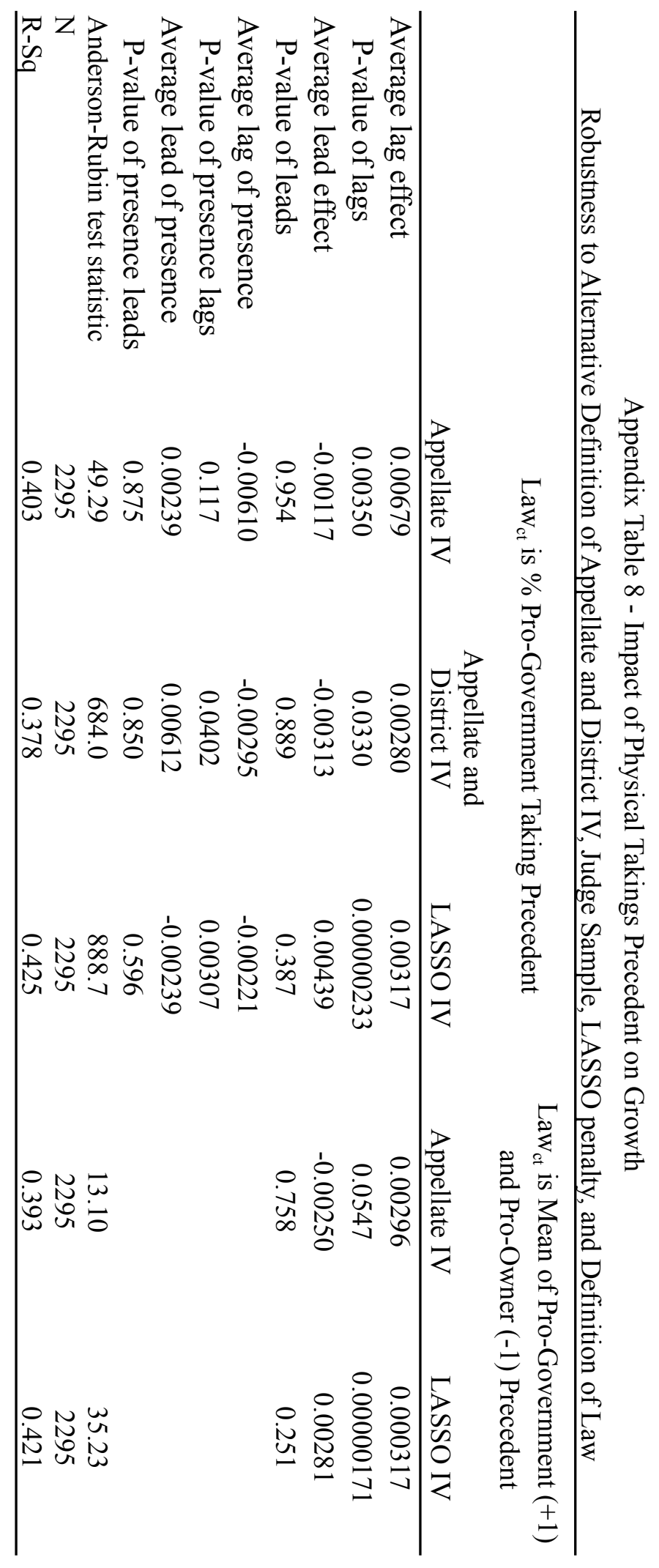


Appendix Table 9: List of Regulatory Takings Appellate Precedent

Citation

605 F.2d 1117

613 F.2d 73

626 F.2d 966

616 F.2d 680

632 F.2d 1014

653 F.2d 364

652 F.2d 585

665 F.2d 138

643 F.2d 1188

666 F.2d 687

660 F.2d 1240

645 F.2d 701

694 F.2d 476

684 F.2d 1301

669 F.2d 105

671 F.2d 432

686 F.2d 1327

718 F.2d 789

710 F.2d 1097

707 F.2d 524

703 F.2d 1141

706 F.2d 1130

707 F.2d 103

724 F.2d 1247

711 F.2d 582

718 F.2d 628

749 F.2d 1396

734 F.2d 175

728 F.2d 876

739 F.2d 1562

725 F.2d 695

729 F.2d 402

762 F.2d 1124

749 F.2d 541

740 F.2d 792

700 F.2d 37

732 F.2d 312

736 F.2d 1207

765 F.2d 756

727 F.2d 1121

739 F.2d 118

727 F.2d 287

749 F.2d 549

771 F.2d 707

764 F.2d 796

780 F.2d 1448

833 F.2d 1270

799 F.2d 317

828 F.2d 23

819 F.2d 1002

816 F.2d 907

809 F.2d 508

834 F.2d 1488

820 F.2d 982
Case Name

Willam C. H1s \& Co. v. San Francisco

Chatham v. Jackson

FTC v. Owens-Corning Fiberglas Corp.

Rogin v. Bensalem Twp.

Union Carbride Agricultural Products Co. v. Costle

Amer. Sav. \& Loan Asso. v. County of Marin

Couf v. De Blaker

Devines v. Maier

Hernandez v. LaFayette

Melo-Tone Vending, Inc. v. US

Minnesota by Alexander v. Block

Nance v. EPA

Barbian v. Panagis

In re Aircrash in Bali

In re Ashe

Nasser v. Homewood

PVM Redwood Co. v. USA

Amen v. Dearborn

Frazier v. Lownes County, Miss. Bd. Of Ed.

Kizas v. Webster

Martino v. Santa Clara Valley Water Dist.

Memorial Hospital v. Heckler

Ocean Acres Ltd. Partnership v. Dare Cty Bd. Of Health

Peick v. Pension Ben. Guaranty Corp.

Price v. Junction

Rep. Indus. V. Teamster Joint Council No. 83

Board of Trustees v. Thompson Bldg. Materials, Inc.

Coastland Corp. v. County of Currituck

Devines v. Maier

Dirt, Inc. v. Mobile County Com.

Family Div. Trial Lawyers of Superior Ct - DC v. Moultrie

Hamilton Bank of Johnson City v. Williamson Cty Reg. Planning

Keith Fulton \& Sons v. NE Teamster \& Trucking

MacLeod v. County of Santa Clara

Mountain States Legal Found. v. Clark

Park Ave. Tower Associates v. NY

Sadowsky v. NY

Scott v. Sioux City

Sederquist v. Tiburon

Silverman v. Barry

Terson Co. v. Bakery Drivers \& Salesman Local 194

Troy Ltd. v. Renna

Trustees for Alaska v. US EPA

Keystone Bituminous Coal Ass'n v. Duncan

Rymer v. Douglas County

Furey v. Sacramento

Hall v. Santa Barbara

In re Chicago, M., S.P. \& P. R. Co.

Citizen's Asso. Of Portland v. Internat'l Raceways, Inc.

Cone v. The State Bar of Florida

Empire Kosher Poultry v. Hallowell

Gorrie v. Bowen

Herrington v. County of Sonoma

In re Consolidated US Atmosheric Testing Litig.
Circuit Year Pro-Property Owner

$91979 \quad 0$
5

$\begin{array}{lll}51980 & 0\end{array}$

$\begin{array}{lll}12 & 1980 & 0\end{array}$

$\begin{array}{lll}3 & 1980 & 0\end{array}$

$21980 \quad 0$

9 1981 1

$51981 \quad 0$

$71981 \quad 1$

$51981 \quad 1$

$11981 \quad 0$

$81981 \quad 0$

$91981 \quad 0$

$\begin{array}{lll}7 & 1982 & 0\end{array}$

$91982 \quad 1$

$31982 \quad 0$

$11 \quad 1982 \quad 0$

$\begin{array}{lll}9 & 1982 & 0\end{array}$

$\begin{array}{lll}6 & 1983 & 1\end{array}$

$\begin{array}{lll}5 & 1983 & 0\end{array}$

$121983 \quad 0$

$91983 \quad 1$

$\begin{array}{lll}11 & 1983 & 0\end{array}$

$41983 \quad 0$

$\begin{array}{lll}7 & 1983 & 0\end{array}$

$51983 \quad 0$

$41983 \quad 0$

$91984 \quad 0$

$41984 \quad 0$

$\begin{array}{lll}7 & 1984 & 0\end{array}$

$\begin{array}{lll}11 & 1984 & 0\end{array}$

$\begin{array}{lll}12 & 1984 & 1\end{array}$

$\begin{array}{lll}6 & 1984 & 1\end{array}$

$11984 \quad 0$

$9 \begin{array}{lll}9 & 1984 & 0\end{array}$

$\begin{array}{lll}10 & 1984 & 1\end{array}$

$21984 \quad 0$

$21984 \quad 0$

$81984 \quad 0$

$9 \begin{array}{lll}9 & 1984 & 1\end{array}$

$\begin{array}{lll}12 & 1984 & 1\end{array}$

$31984 \quad 0$

$31984 \quad 0$

$\begin{array}{lll}9 & 1984 & 0\end{array}$

319850

$\begin{array}{lll}11 & 1985 & 0\end{array}$

$9 \begin{array}{lll}9 & 1986 & 0\end{array}$

$91986 \quad 1$

$71986 \quad 0$

$9 \begin{array}{lll}9 & 1987 & 0\end{array}$

$\begin{array}{lll}11 & 1987 & 0\end{array}$

$\begin{array}{lll}3 & 1987 & 0\end{array}$

$81987 \quad 0$

$\begin{array}{lll}9 & 1987 & 1\end{array}$

$\begin{array}{lll}9 & 1987 & 0\end{array}$ 
818 F.2d 1449

841 F.2d 872

861 F.2d 727

854 F.2d 732

840 F.2d 678

847 F.2d 304

837 F.2d 546

841 F.2d 301

844 F.2d 172

851 F.2d 1501

842 F.2d 598

862 F.2d 184

853 F.2d 145

841 F.2d 107

873 F.2d 1407

865 F.2d 1395

879 F.2d 316

870 F.2d 529

868 F.2d 335

874 F.2d 1070

886 F.2d 260

876 F.2d 1013

902 F.2d 905

919 F.2d 1385

920 F.2d 1496

898 F.2d 573

900 F. 2 d 783

909 F.2d 608

913 F.2d 573

917 F.2d 1150

905 F.2d 595

898 F.2d 347

914 F.2d 348

907 F.2d 239

922 F.2d 498

911 F.2d 1331

895 F.2d 780

948 F.2d 575

941 F.2d 872

939 F.2d 165

922 F.2d 1536

935 F.2d 691

939 F.2d 696

942 F.2d 668

945 F.2d 667

947 F.2d 1158

940 F.2d 925

938 F.2d 951

973 F.2d 704

953 F.2d 600

967 F.2d 648

969 F.2d 664

959 F.2d 395

978 F.2d 1269

968 F.2d 1131

959 F.2d 1268
Kinzli v. Santa Cruz

Lake Nacimiento Ranch Co. v. County of San Luis Obispo

A.A. Profiles, Inc. v. Ft. Lauderdale

Adolph v. Fed. Emergency Mngment Agency

Austin v. Honululu

Calvert Invest., Inc. v. Louisville \& Jefferson Cty Metro.

Carlin Communications, Inc. v. FCC

Lai v. Honolulu

Naegele Outdoor Advertising v. Durham

Nat. Wildlife Fed. v. ICC

Pineman v. Fallon

Pinkham v. Lewiston Orchards Irrigation Dist.

Presault v. Interstate Commerce Comm.

SDJ, Inc. v. Houston

Baytree of Inverrary Realty Partners v. Lauderhill

Bennett v. White

Glosemeyer v. Missouri K.T. Railroad

Hoehne v. County of San Benito

In re Southeast Co.

Jackson Ct Condos, Inc. v. New Orleans

Moore v. Costa Mesa

Tenoco Oil Co. v. Dep't of Cons. Affairs

Centel Cable Television Co. v. Thos. J. White Dev. Corp.

Conti v. Fremont

Del Monte Dunes v. City of Monterey

Estate of Himelstein v. Ft. Wayne

GA Outdoor Advertising, Inc. v. Waynesville

Hoffman v. Warwick

Kaiser Dev. Co. v. Honolulu

Lockary v. Kayfetz

Mehta v. Surles

Pinewood Estates of MI v. Barnegat Twp Lev Bd.

Rector, Wardens \& Members of Vestry of St. Bart's Church

Smithfield Concerned Ctzns. for Fair Zng. v.Smithfield

Southern Pac. Transp. Co. v. L.A.

Tahoe-Sierra Preservation Council, Inc. v. Tahoe Reg'l Planning

Western Fuels-Utah, Inc. v. Lujan

Azul Pacifico, Inc. v. L.A.

Commercial Builders of Northern CA v. Sacramento

Esposito v. SC Coastal Council

Executive 100 v. Martin County

Federal Sav. \& Loan Ins. Corp. v. Griffin

Leroy Land Dev. v. Tahoe Regional Planning Agency

McDougal v. County of Imperial

Midnight Sessions, Ltd. v. Philadelphia

Nat. Advert. Co. v. Raleigh

Sam1d v. Dallas

Sierra Lake Reserve v. Rocklin

Azul Pacifico, Inc. v. L.A.

Cable Holdings of G. v. McNeil Real Estate Fund VI

Colorado Springs Prod. Credit Ass'n v. Farm Credit Admin.

Get Away Club, Inc. v. Coleman

Kraebel v. NYC Dep't of Housing Preservation \& Dev.

Nixon v. US

Reahard v. Lee County

Rogers v. Bucks Cty Dom Rel Section
$91987 \quad 0$

$91987 \quad 0$

$\begin{array}{lll}11 & 1988 & 1\end{array}$

$51988 \quad 0$

$\begin{array}{lll}9 & 1988 & 0\end{array}$

$\begin{array}{lll}6 & 1988 & 0\end{array}$

$21988 \quad 0$

$\begin{array}{lll}9 & 1988 & 0\end{array}$

$\begin{array}{lll}4 & 1988 & 1\end{array}$

$\begin{array}{lll}12 & 1988 & 1\end{array}$

$\begin{array}{lll}2 & 1988 & 0\end{array}$

$\begin{array}{llll}9 & 1988 & 0\end{array}$

$\begin{array}{lll}2 & 1988 & 0\end{array}$

$\begin{array}{lll}5 & 1988 & 0\end{array}$

$\begin{array}{lll}11 & 1989 & 0\end{array}$

$31989 \quad 1$

$81989 \quad 0$

$\begin{array}{lll}9 & 1989 & 1\end{array}$

$\begin{array}{lll}9 & 1989 & 0\end{array}$

$\begin{array}{lll}5 & 1989 & 0\end{array}$

$\begin{array}{lll}9 & 1989 & 0\end{array}$

$11989 \quad 0$

$\begin{array}{lll}11 & 1990 & 0\end{array}$

$9 \begin{array}{lll}9 & 1990 & 0\end{array}$

$9 \begin{array}{lll}9 & 1990 \quad 1\end{array}$

$\begin{array}{lll}7 & 1990 & 0\end{array}$

$41990 \quad 1$

$11990 \quad 0$

$\begin{array}{lll}9 & 1990 & 0\end{array}$

$9 \begin{array}{lll}9 & 1990 & 0\end{array}$

$21990 \quad 0$

$\begin{array}{lll}3 & 1990 & 1\end{array}$

$\begin{array}{lll}2 & 1990 & 0\end{array}$

$11990 \quad 0$

$\begin{array}{lll}9 & 1990 & 0\end{array}$

$91990 \quad 0$

$\begin{array}{lll}12 & 1990 & 0\end{array}$

$\begin{array}{lll}9 & 1991 & 0\end{array}$

$91991 \quad 0$

$41991 \quad 0$

$111991 \quad 0$

$51991 \quad 0$

9 1991 0

$\begin{array}{lll}9 & 1991 & 1\end{array}$

$31991 \quad 0$

$41991 \quad 0$

$\begin{array}{lll}5 & 1991 & 0\end{array}$

$9 \begin{array}{lll}9 & 1991 & 1\end{array}$

$91992 \quad 0$

$\begin{array}{lll}11 & 1992 & 1\end{array}$

$121992 \quad 0$

$81992 \quad 0$

$21992 \quad 0$

$121992 \quad 1$

$\begin{array}{lll}11 & 1992 & 0\end{array}$

$31992 \quad 0$ 
980 F.2d 84

2 F. $3 d 276$

995 F.2d 161

5 F.3d 285

987 F.2d 913

1 F.3d 121

998 F.2d 680

989 F.2d 13

985 F.2d 36

985 F.2d 1488

997 F.2d 604

998 F.2d 1073

995 F.2d 1179

993 F.2d 962

42 F.3d 1185

24 F.3d 1441

37 F.3d 468

43 F.3d 1476

14 F.3d 44

19 F.3d 215

21 F.3d 1214

13 F.3d 1192

18 F.3d 111

47 F.3d 832

70 F.3d 1566

59 F.3d 852

57 F.3d 781

49 F.3d 1263

53 F.3d 478

62 F.3d 449

65 F.3d 1113

57 F.3d 505

67 F.3d 194

101 F.3d 320

89 F.3d 704

89 F.3d 1481

79 F.3d 516

85 F.3d 422

95 F.3d 1066

75 F.3d 1114

95 F.3d 1422

83 F.3d 45

90 F.3d 306

74 F.3d 694

90 F.3d 688

83 F.3d 1531

103 F.3d 690

93 F.3d 301

96 F.3d 401

101 F.3d 1095

90 F.3d 790

121 F.3d 695

110 F.3d 150

126 F.3d 1125

112 F.3d 313

124 F.3d 1150
Southview Assoc., Ltd. v. Bongartz

Armour \& Co. v. Inver Grove Heights

Christenson v. Yolo County Bd. Of Supervisors

Gamble v. Eau Claire County

Garelick v. Sullivan

Hertz Corp. v. City of NY

Levald, Inc. v. City of Palm Desert

McAndrews v. Fleet Bank of MA

McMurray v. Commissioner

New Port Largo v. Monroe County

Outdoor Sys., Inc. v. City of Mesa

Tri-State Rubbish, Inc. v. Waste Management, Inc.

United Wire, Metal \& Mach. Health \& Welfare Fund v. Morristown

Washington Legal Found. v. MA Bar Found.

Barber v. Hawaii

Bell Atl. Tel. Cos. v. FCC

Carson Harbor Village Ltd. v. City of Carson

Christopher Lake Dev. Co. v. St. Louis Cty.

Lovell v. Peoples Heritage Sav. Bank

Matagorda County v. Russell Law

Orange Lake Assocs. V. Kirkpatrick

Parkridge Investors Ltd. Partnership by Mortimer v. Farmers Home

Res. Trust Corp. v. Diamond

Barrick Gold Exploration v. Hudson

Clajon Prod. Corp. v. Petera

Dodd v. Hood River County

Hoeck v. City of Portland

LB Credit Corp. v. Resolution Trust Corp.

LTV Steel Co. v. Shalala

Meriden Trust \& Safe Deposit Co. v. FDIC

Multi-Channel TV Cable Co. v. Charlottesville Quality Cable Corp.

Pro-Eco v. Board of Comm'rs

Youppee v. Babbitt

287 Corp Center Assoc. v. The Twp of Bridgewater

Bateman v. City of W. Bountiful

Bickerstaff Clay Prods. Co. v. Harris County

Blue Diamond Coal Co. v. Sec of HHS

Broad v. Sealaska

Corn v. City of Lauderdale Lakes

Davon, Inc. v. Shalala

Del Monte Dunes v. City of Monterey

Fed. Home Loan Mortg. Corp. v. NY State Div. Of Hous. \& Comm. Renewal

Goss v. City of Little Rock

Kruse v. Village of Chargrin Falls

Lindsey Coal Mining Co. v. Chater

NJ v. USA

Outdoor Graphics v. City of Burlington

Porter v. DiBlasio

Sinclair Oil Corp. v. County of Santa Barbara

TX Manufactured Hous. Ass'n v. City of Nederland

United States v. 30.54 Acres of Land

Cape Ann Citizens Ass'n v. City of Gloucester

Eastern Enters. v. Chater

Macri v. King County

McKenzie v. City of White Hall

Richardson v. City \& County of Honolulu
$21992 \quad 0$

$81993 \quad 0$

$91993 \quad 0$

$\begin{array}{lll}7 & 1993 & 0\end{array}$

$21993 \quad 0$

$21993 \quad 0$

$91993 \quad 0$

$11993 \quad 0$

$11993 \quad 0$

$\begin{array}{lll}11 & 1993 & 1\end{array}$

$\begin{array}{lll}9 & 1993 & 0\end{array}$

$11993 \quad 0$

$31993 \quad 0$

$11993 \quad 0$

$91994 \quad 0$

$\begin{array}{lll}12 & 1994 & 1\end{array}$

$\begin{array}{lll}9 & 1994 & 0\end{array}$

$81994 \quad 1$

$11994 \quad 0$

$\begin{array}{lll}5 & 1994 & 0\end{array}$

$21994 \quad 0$

$\begin{array}{lll}8 & 1994 & 0\end{array}$

$21994 \quad 0$

$\begin{array}{lll}6 & 1995 & 0\end{array}$

$\begin{array}{lll}10 & 1995 & 0\end{array}$

$\begin{array}{lll}9 & 1995 & 1\end{array}$

$91995 \quad 0$

$71995 \quad 0$

$21995 \quad 0$

$21995 \quad 0$

$41995 \quad 0$

$71995 \quad 0$

$\begin{array}{lll}9 & 1995 & 1\end{array}$

$31996 \quad 0$

$101996 \quad 0$

$111996 \quad 1$

$\begin{array}{lll}6 & 1996 & 0\end{array}$

$91996 \quad 0$

$\begin{array}{lll}11 & 1996 & 0\end{array}$

$\begin{array}{lll}7 & 1996 & 0\end{array}$

$\begin{array}{lll}9 & 1996 & 1\end{array}$

$21996 \quad 0$

$81996 \quad 1$

$\begin{array}{lll}6 & 1996 & 1\end{array}$

$\begin{array}{lll}3 & 1996 & 0\end{array}$

$31996 \quad 0$

$81996 \quad 0$

$\begin{array}{lll}7 & 1996 & 0\end{array}$

$\begin{array}{lll}9 & 1996 & 0\end{array}$

$51996 \quad 0$

$31996 \quad 0$

$11997 \quad 0$

$11997 \quad 0$

$\begin{array}{lll}9 & 1997 & 0\end{array}$

$81997 \quad 0$

$\begin{array}{lll}9 & 1997 & 0\end{array}$ 
121 F.3d 610

130 F.3d 731

136 F.3d 1219

135 F.3d 275

147 F.3d 802

151 F.3d 861

138 F.3d 1036

153 F.3d 356

159 F.3d 670

145 F.3d 1095

151 F.3d 1194

160 F.3d 834

158 F.3d 729

141 F.3d 1427

195 F.3d 1225

191 F.3d 1127

198 F.3d 642

198 F.3d 874

175 F.3d 178

172 F. $3 \mathrm{~d} 22$

172 F.3d 906

164 F.3d 677

170 F.3d 961

178 F.3d 649

224 F.3d 1030

214 F.3d 573

228 F.3d 998

227 F.3d 170

226 F.3d 412

266 F.3d 487

254 F.3d 89

263 F.3d 286

267 F. $3 d 45$

271 F.3d 835

270 F.3d 180

306 F.3d 113

288 F.3d 375

306 F.3d 445

285 F.3d 142

307 F.3d 978

312 F. $3 d 24$

289 F.3d 417

284 F.3d 148

276 F.3d 1014

342 F.3d 118

345 F.3d 1083

374 F.3d 887

363 F. $3 d 846$

365 F.3d 435

362 F.3d 512

366 F.3d 1186

361 F.3d 934

375 F.3d 936

369 F.3d 882
Villas of Lake Jackson v. Leon County

Waste Mgmt. v. Metropolitan Gov't

Dodd v. Hood River County

Front Royal \& Warren Cty Indus. Pk. Corp. v. Town of Front Royal

Garneau v. City of Seattle

Goss v. City of Little Rock

Hidden Oaks v. City of Austin

Int'l College of Surgeons v. City of Chicago

Philip Morris v. Harshbarger

San Remo Hotel v. City \& Cty of San Francisco

Schneider v. Cal Dep't of Corrections

South County Sand \& Gravel Co. v. Town of S. Kingstown

Stern v. Halligan

Vesta Fire Ins. Co. v. Florida

Agripost, Inc. v. Miami-Dade County

Buckles v. King County

Central States, SE and SW Areas Pension Fund v. Midwest

District Intown Props. Ltd. Pshp. v. D.C.

Houlton Citizens' Coalition v. Town of Houlton

Nat. Educ. Ass'n-Rhode Island v. Retirement Bd.

National Mining Ass'n v. Babbitt

Patriot Portfolio, LLC v. Weinstein

Quarty v. USA

Unity Real Estate v. Hudson

Chevron USA, Inc. v. Cayetano

John Corp. v. City of Houston

Tahoe-Sierra Preservation Council, Inc. v. Tahoe Reg'l Planning

Traficanti v. USA

US Fid. \& Guar. Co. v. McKeithen

Anderson v. Charter Twp. Of Ypsilanti

Bldg. Owners \& Managers Ass'n Int'l v. FCC

Cowell v. Palmer Twp.

Philip Morris, Inc. v. Reilly

Wash. Legal Found. v. Legal Found. Of Wash.

Wash. Legal Found. v. Tex. Equal Access to Justice Found.

Barefoot v. City of Wilmington

Daniel v. County of Santa Barbara

Daniels v. Area Plan Comm'n

Deniz v. Municpality of Guaynabo

Esplanade Props. V. City of Seatthle

Philip Morris, Inc. v. Reilly

Prater v. City of Burnside

Sinclair Broadcast Group v. FCC

United States v. Kornwolf

Santini v. Conn. Hazardous Waste Mgmt. Serv.

Vance v. Barrett

Cashman v. City of Cotati

Chevron USA, Inc. v. Bronster

Coalition for Gov't Procurement v. Fed. Prison Indus.

Dakota, Minn. \& R.R. Corp. v. S.D.

Garvie v. City of Fort Walton Beach

Greenfield Mills, Inc. v. Macklin

Squaw Valley Dev. Co. v. Goldberg

Vulcan Materials Co. v. City of Tehuacana $\begin{array}{lll}11 & 1997 & 0\end{array}$

$\begin{array}{lll}6 & 1997 & 1\end{array}$

$\begin{array}{lll}9 & 1998 & 0\end{array}$

$\begin{array}{lll}4 & 1998 & 0\end{array}$

$\begin{array}{lll}9 & 1998 & 0\end{array}$

$\begin{array}{ll}8 & 1998\end{array}$

$\begin{array}{ll}5 & 1998\end{array}$

$\begin{array}{ll}7 & 1998\end{array}$

11998

$\begin{array}{ll}9 & 1998\end{array}$

$9 \quad 1998$

11998

31998

$\begin{array}{ll}11 & 1998\end{array}$

$11 \quad 1999$

$\begin{array}{ll}9 & 1999\end{array}$

$\begin{array}{ll}7 & 1999\end{array}$

121999

11999

11999

121999

11999

$\begin{array}{ll}9 & 1999\end{array}$

31999

$\begin{array}{ll}9 & 2000\end{array}$

$5 \quad 2000$

92000

42000

$\begin{array}{ll}5 & 2000\end{array}$

$6 \quad 2001$

$12 \quad 2001$

32001

12001

$\begin{array}{ll}9 & 2001\end{array}$

52001

$4 \quad 2002$

$9 \quad 2002$

$7 \quad 2002$

12002

$9 \quad 2002$

12002

$6 \quad 2002$
6

$12 \quad 2002$

$8 \quad 2002$

22003

$9 \quad 2003$

$9 \quad 2004$

$\begin{array}{ll}9 & 2004\end{array}$

$\begin{array}{ll}6 & 2004\end{array}$

\begin{tabular}{ll}
$8 \quad 2004$ \\
\hline
\end{tabular}

$11 \quad 2004$

$7 \quad 2004$

$\begin{array}{ll}9 & 2004\end{array}$

$5 \quad 2004$ 


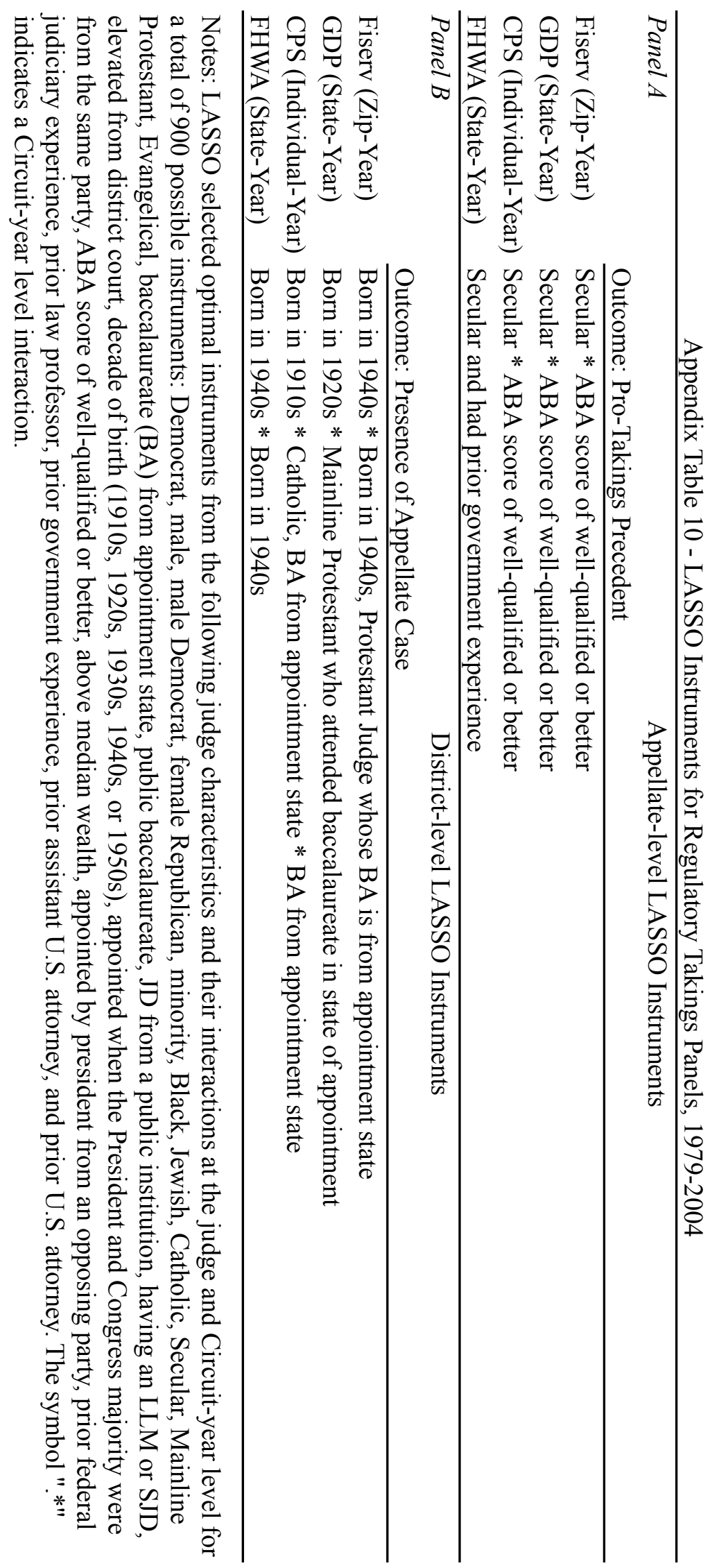

